\section{Pacific Northwest}

National Laboratory

Operated by Battelle for the

U.S. Department of Energy

\section{Technical Scope and Approach for the 2004 Composite Analysis of Low Level Waste Disposal at the Hanford Site}

C.T. Kincaid

R.W. Bryce

J.W. Buck

June 2004

Prepared for the U.S. Department of Energy under Contract DE-AC06-76RL01830 


\title{
Technical Scope and Approach for the 2004 Composite Analysis of Low Level Waste Disposal at the Hanford Site
}

\author{
CT Kincaid \\ RW Bryce \\ JW Buck
}

June 2004

Prepared for

the U.S. Department of Energy

under Contract DE-AC06-76RL01830

Pacific Northwest National Laboratory

Richland, Washington 99352 


\section{Summary}

A Composite Analysis is required by U.S. Department of Energy (DOE) Order 435.1 to ensure public safety through the management of active and planned low-level radioactive waste disposal facilities associated with the Hanford Site. A Composite Analysis is defined as "a reasonably conservative assessment of the cumulative impact from active and planned low-level waste disposal facilities, and all other sources from radioactive contamination that could interact with the low-level waste disposal facility to affect the dose to future members of the public." At the Hanford Site, a Composite Analysis is required for continued disposal authorization for the immobilized low-activity waste (ILAW), spent vitrification plant melter components, low-level waste in the 200 East and 200 West Solid Waste Burial Grounds or the Integrated Disposal Facility to be located in the 200 East Area, and Comprehensive Environmental Response, Compensation, and Liability Act (CERCLA) waste in the Environmental Restoration Disposal Facility (ERDF).

The 2004 Composite Analysis will be a site-wide analysis, considering final remedial actions for the Columbia River Corridor and the Central Plateau. The river corridor includes waste sites and facilities in each of the 100 Areas as well as the 300, 400, and 600 Areas. The "Central Plateau" describes the region associated with operations and waste sites of the 200 Areas. DOE is developing a strategy for closure of the Central Plateau area by 2035. At the time of closure, waste management activities will shrink to a Core Zone within the Central Plateau. The Core Zone will contain the majority of Hanford's permanently disposed waste. Figure 1.1 shows the Core Zone, Central Plateau, Hanford Site (also known as the Columbia River Corridor), and Hanford Reach National Monument.

The 2004 Composite Analysis will be a companion site-wide assessment to waste-specific and sitespecific assessments. The 2004 Composite Analysis also will provide supporting information on a regional or site-wide basis for use in important Hanford assessments and decisions such as the CERCLA 5-year review in 2005, tank closure decisions, decisions on final groundwater remedies for the 200 Areas, decisions on final groundwater remedies for the 100 Areas, and the Columbia River corridor final record of decision.

The purpose of this document is to describe the technical scope of the 2004 Composite Analysis for the Hanford Site and the approach to perform this analysis. This document describes the performance and data quality objectives, region involved, contaminants of concern, waste sites to be included, scenarios to be evaluated, spatial and temporal domains for the Composite Analysis, and incorporates information from related studies associated with the 2004 Composite Analysis.

The 2004 Composite Analysis will be a site-wide evaluation of the potential long-term impact on the health of a hypothetical future member of the public. The human health impact will be evaluated from combined radionuclide releases to groundwater, surface water, and air from multiple sources during the 1000-year period following the closure of the Hanford Site. In addition to the analysis required under 
DOE Order 435.1, DOE-RL will perform a supplemental analysis to examine the ecological impact from radiological contaminants and conduct an analysis on a select number of chemicals. This supplemental analysis will, of necessity, have a lower priority than the Composite Analysis and will be published somewhat later. 


\section{Contents}

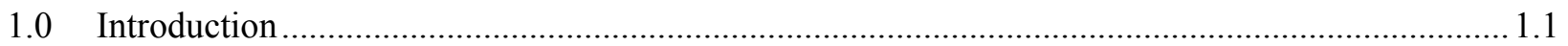

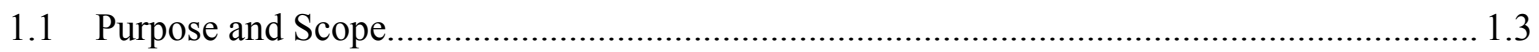

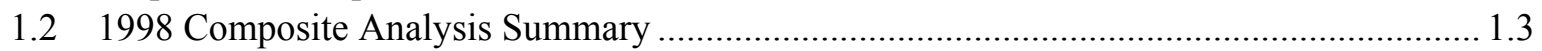

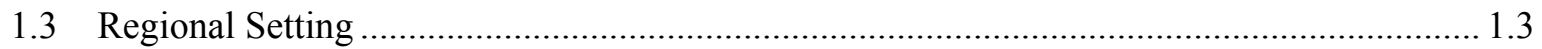

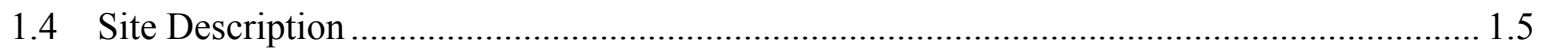

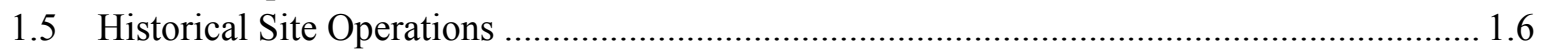

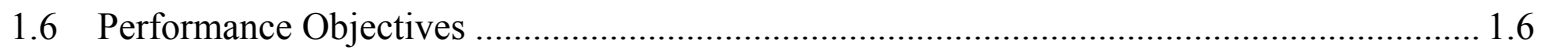

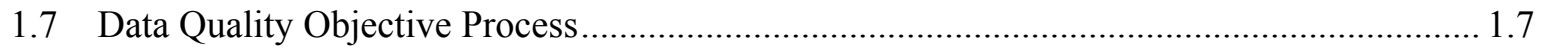

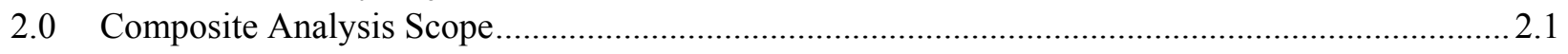

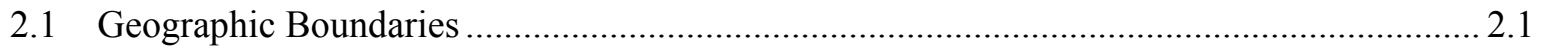

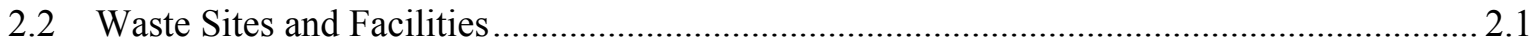

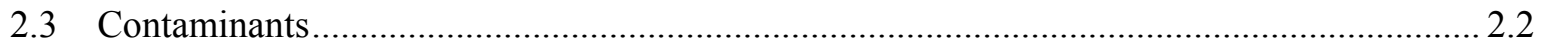

2.4 Past and Planned Waste Management Activities .......................................................... 2.4

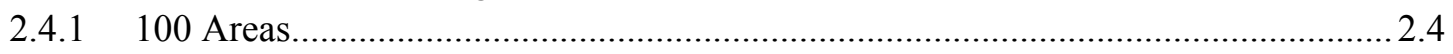

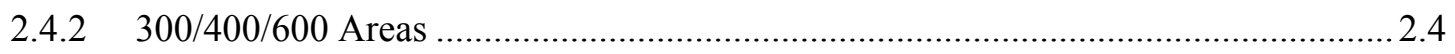

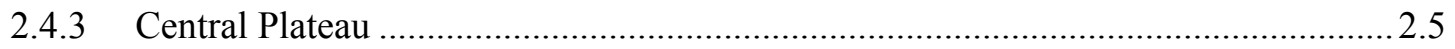

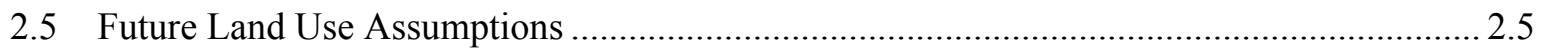

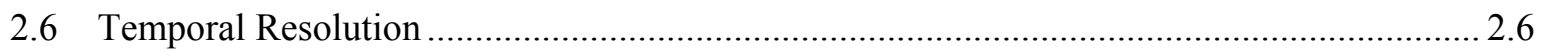

3.0 Technical Approach for Performance of the Composite Analysis .............................................. 3.1

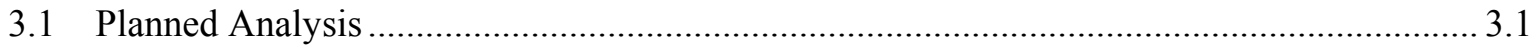

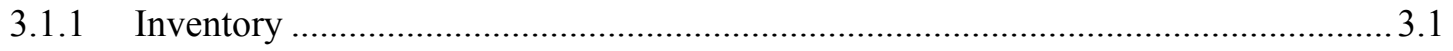

3.1.2 Contaminant Release for Waste Sites and Facilities ........................................... 3.2

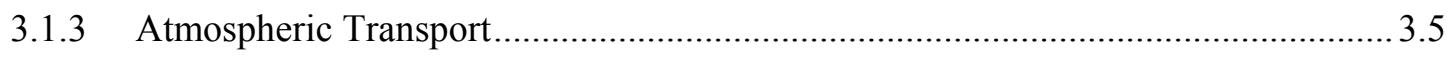

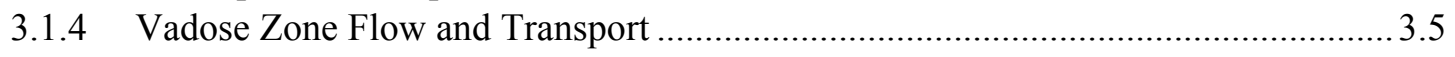

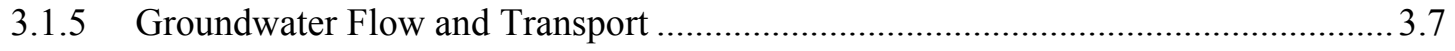

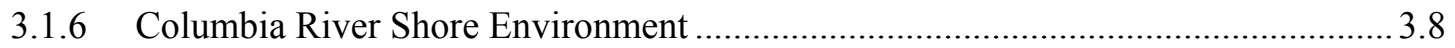

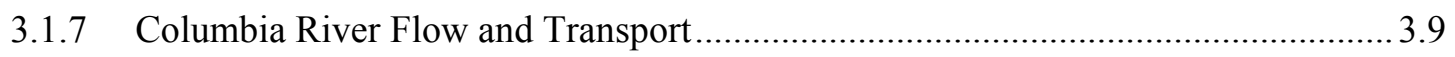

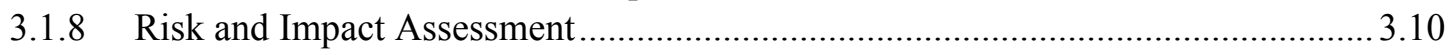

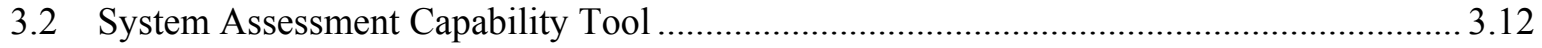

3.3 Incorporation of the Data and Results from Other Studies ........................................... 3.15

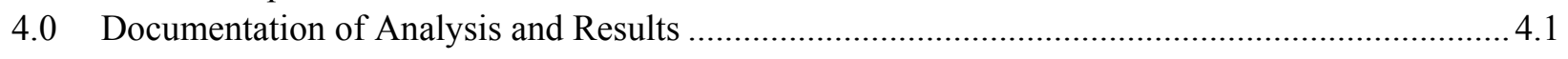

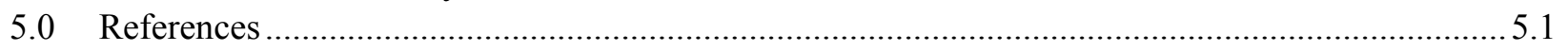

Appendix 2004 Composite Analysis - Modified Data Quality Objectives .......................................... A.1

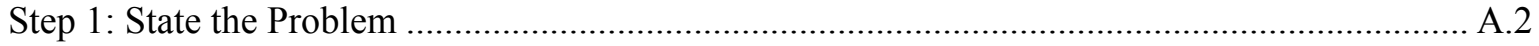

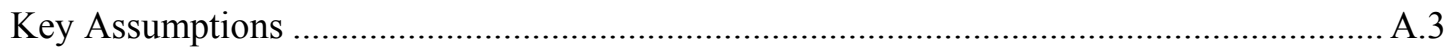

Contaminants of Concern ............................................................................................ A. 3

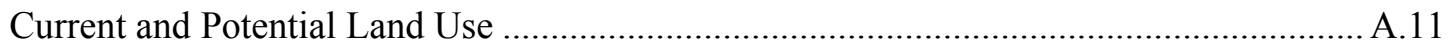

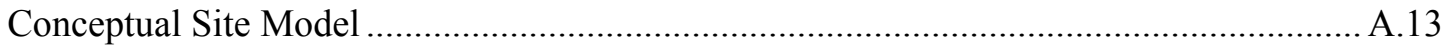

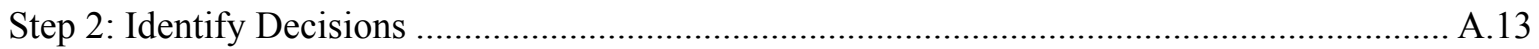

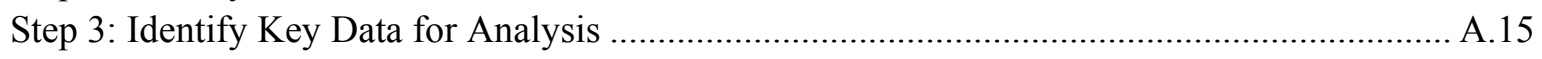

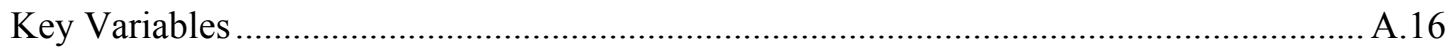

Key Data for Each Waste Site ................................................................................. A.23 


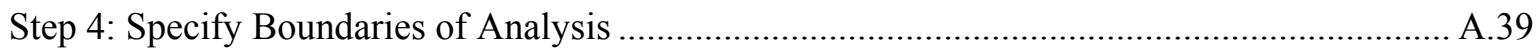

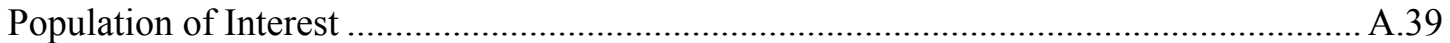

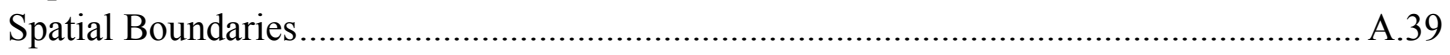

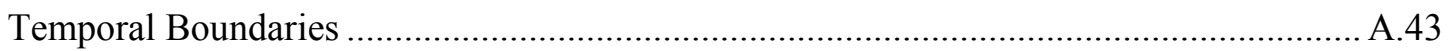

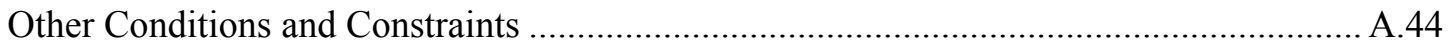




\section{Figures}

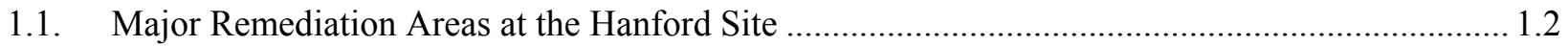

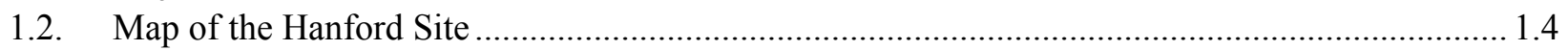

3.1. Conceptual Model of the System Assessment Capability .......................................................... 3.14

A.1. Conceptual Model of Waste Inventory, Environmental Transport Pathways

and Receptors at the Hanford Site.....

\section{Tables}

2.1. List of Contaminants of Concern for Groundwater, Surface Water, and Air Exposure Pathways to Be Included in the 2004 Composite Analysis............................................................................. 2.3

A.1. Data Quality Objective Team Members .............................................................................. A.2

A.2. Contaminants of Potential Concern Selected at February 25, 2003 Workshop........................... A.4

A.3. Radionuclides of Potential Concern Based on Groundwater Monitoring Data from 1990-December 2002 and Ranked by Half-Life .................................................... A.5

A.4. Radionuclides and Their Drinking Water Standards .............................................................. A.7

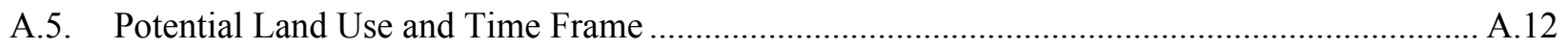

A.6. Key Variables for Waste Site Inventory ................................................................................... A.17

A.7. Key Variables for Contaminant Release from Each Waste Type.............................................. A.17

A.8. Key Variables for Contaminant Transport in the Atmosphere ................................................. A.18

A.9. Key Variables for Flow and Contaminant Transport in the Vadose Zone ............................... A.18

A.10. Key Variable for Contaminant Transport in Groundwater...................................................... A.19

A.11. Key Variables for Contaminant Concentrations in the River Shore Environment ..................... A.19

A.12. Key Variables for Flow and Contaminant Transport in the Columbia River ............................. A.20

A.13. Key Variables for Contaminant Impact on Human Health ................................................... A.20

A.14. Key Variables for Contaminant Impact on Ecological Species............................................... A.22

A.15. Hanford Site Disposition Baseline in Year 2004 for the 100 Areas ........................................ A.23

A.16. Hanford Site Disposition Baseline in Year 2004 for the 300, 400, and 600 Areas .................... A.27

A.17. Hanford Site Disposition Baseline in Year 2004 for the Central Plateau................................... A.31

A.18. Summary of Screening Rules Applied to Identify Waste Sites for the 2004 Composite Analysis 


\subsection{Introduction}

A Composite Analysis is required by U.S. Department of Energy (DOE) Order 435.1 to ensure public safety through the management of active and planned low-level radioactive waste disposal facilities associated with the Hanford Site. A Composite Analysis is defined as "a reasonably conservative assessment of the cumulative impact from active and planned low-level waste disposal facilities, and all other sources from radioactive contamination that could interact with the low-level waste disposal facility to affect the dose to future members of the public." At the Hanford Site, a Composite Analysis is required for continued disposal authorization for the immobilized low-activity waste (ILAW), spent vitrification plant melter components, low-level waste in the 200 East and 200 West Solid Waste Burial Grounds or the Integrated Disposal Facility to be located in the 200 East Area, and Comprehensive Environmental Response, Compensation, and Liability Act (CERCLA) waste in the Environmental Restoration Disposal Facility (ERDF).

A site specific maintenance plan (DOE/RL-2000-29) describes Hanford's implementation of the DOE M435.1-1 guidance. Annual status reports for the Composite Analysis document changes to inventory, site operations, or other changes at the Hanford Site that could affect the conclusion of the original Composite Analysis detailed in PNNL-11800. Annual status reports have been produced for fiscal year (FY) 2000, 2001 and 2002 (for example, DOE/RL-2003-26). The Composite Analysis must be revised and submitted to DOE Headquarters (DOE-HQ) in 2004 because of revisions to waste site information in the 100,200, and 300 Areas, updated performance assessments and environmental impact statements (EIS), changes in inventory estimates for key sites and constituents, and a change in the definition of offsite receptors. Beginning in FY2003, the DOE Richland Operations Office (DOE-RL) initiated activities, including this technical scope document, to support the 2004 revision.

The 2004 Composite Analysis will be a site-wide analysis, considering final remedial actions for the Columbia River Corridor and the Central Plateau. The river corridor includes waste sites and facilities in each of the 100 Areas as well as the 300, 400, and 600 Areas. The "Central Plateau" describes the region associated with operations and waste sites of the 200 Areas. DOE is developing a strategy for closure of the Central Plateau area by 2035. At the time of closure, waste management activities will shrink to a Core Zone within the Central Plateau. The Core Zone will contain the majority of Hanford's permanently disposed waste. Figure 1.1 shows the Core Zone, Central Plateau, Hanford Site (also known as the Columbia River Corridor), and Hanford Reach National Monument (65 FR 37253).

The 2004 Composite Analysis will be a companion site-wide assessment to waste-specific and sitespecific assessments. The 2004 Composite Analysis also will provide supporting information on a regional or site-wide basis for use in important Hanford assessments and decisions such as the CERCLA 5 -year review in 2005, tank closure decisions, decisions on final groundwater remedies for the 200 Areas, decisions on final groundwater remedies for the 100 Areas, and the Columbia River corridor final record of decision. 


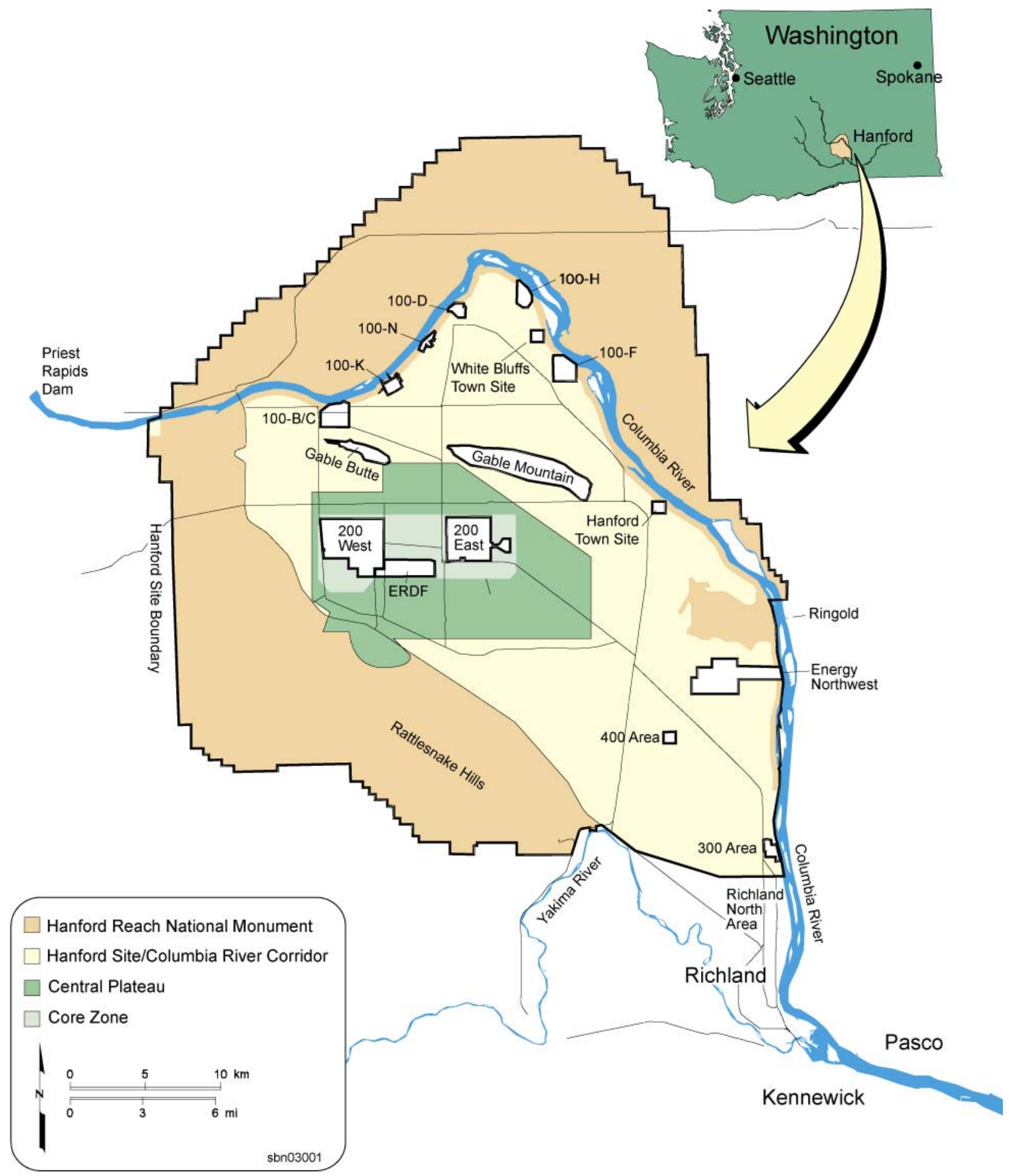

Figure 1.1. Major Remediation Areas at the Hanford Site 


\subsection{Purpose and Scope}

The purpose of this document is to describe the technical scope of the 2004 Composite Analysis for the Hanford Site and the approach to perform this analysis. This document describes the performance and data quality objectives, region involved, contaminants of concern, waste sites to be included, scenarios to be evaluated, spatial and temporal domains for the Composite Analysis, and incorporates information from related studies associated with the 2004 Composite Analysis.

The 2004 Composite Analysis will be a site-wide evaluation of the potential long-term impact on the health of a hypothetical future member of the public. The human health impact will be evaluated from combined radionuclide releases to groundwater, surface water, and air from multiple sources during the 1000-year period following the closure of the Hanford Site. In addition to the analysis required under DOE Order 435.1, DOE-RL will perform a supplemental analysis to examine the ecological impact from radiological contaminants and conduct an analysis on a select number of chemicals. This supplemental analysis will, of necessity, have a lower priority than the Composite Analysis and will be published somewhat later.

\subsection{Composite Analysis Summary}

The 1998 Composite Analysis documented in PNNL-11800 was an early attempt at the Hanford Site to estimate the cumulative impact of radiological sources in and around the Central Plateau. The 1998 Composite Analysis assessed cumulative dose to hypothetical future members of the public who might access the area between the Central Plateau and the Columbia River during the 1000 years after 2050, the postulated year of Hanford Site closure at the time of the assessment.

Results of the 1998 assessment showed the maximum predicted all pathways dose occurred from an agricultural scenario consistent with a land use of farm residences located downwind and downgradient of the Central Plateau. This exposure to a hypothetical member of the offsite public outside the Central Plateau was less than 6 millirem in 2050 (closure date planned at time of 1998 study) and declined thereafter. This dose was primarily attributable to existing plumes of tritium and iodine-129. The maximum dose estimated for the other hypothetical scenarios (residential, industrial, and recreational) were 2.2, 0.7, and 0.04 millirem in a year, respectively, and also declined after 2050.

The results of the 1998 Composite Analysis (PNNL-11800) showed no dose above the decision rule limits specified for a composite analysis under DOE Order 435.1. The decision rule limits are 100 millirem/year (primary dose limit above which DOE needs to alter its waste disposal plan) and 30 millirem/year (dose constraint limit above which DOE must study the issue using an ALARA-as low as reasonably achievable-assessment) to decide if a different approach to waste disposal will lead to substantially lower doses).

\subsection{Regional Setting}

The Hanford Site lies within the semiarid Pasco Basin of the Columbia Basin in southeastern Washington State (Figure 1.2). The Columbia River flows eastward through the northern part of the Hanford Site and then turns south, forming part of the eastern site boundary. The Yakima River flows near a portion of the southern boundary and joins the Columbia River downstream of the city of Richland. 


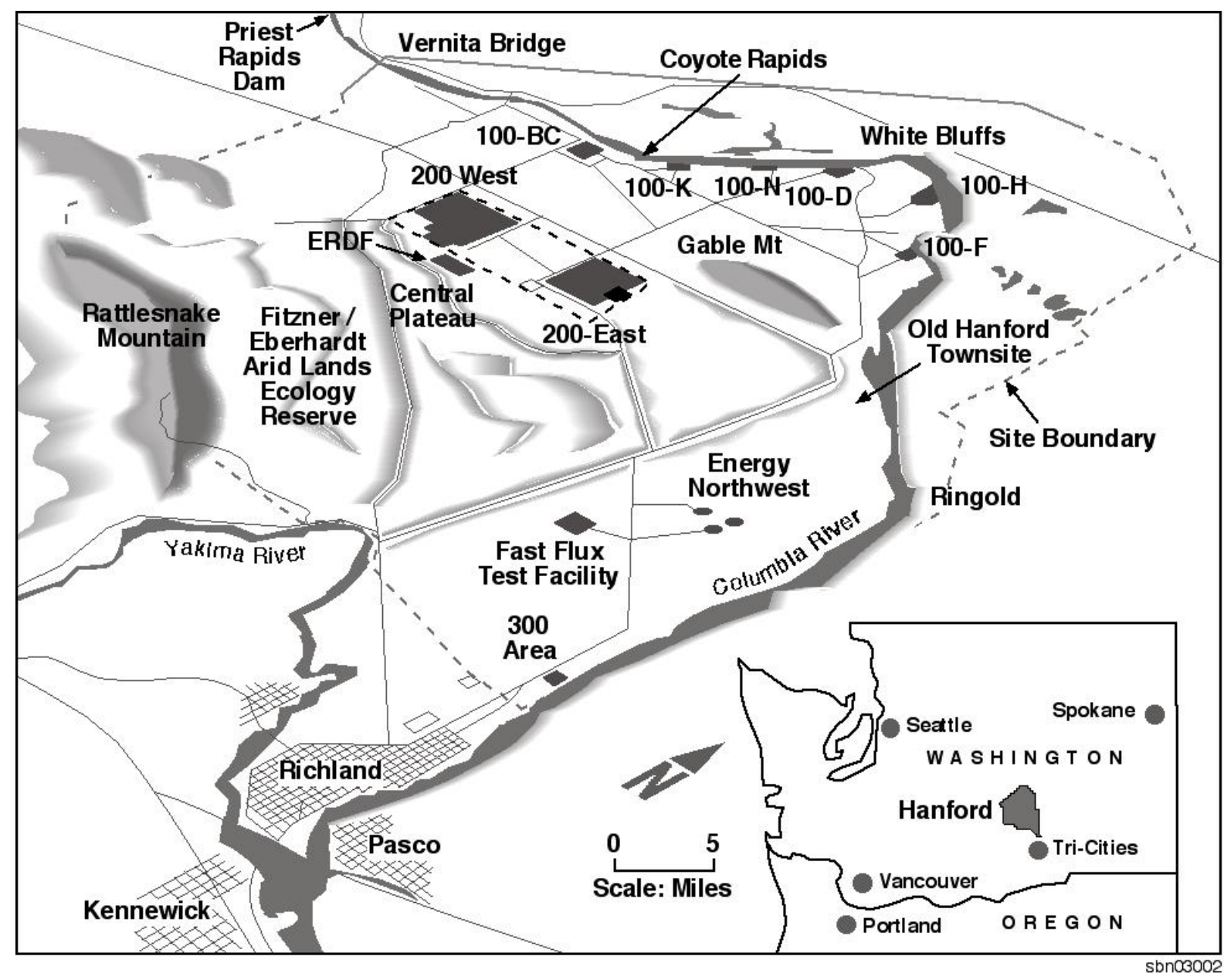

Figure 1.2. Map of the Hanford Site

The Hanford Site occupies an area of approximately 1517 square kilometers (approximately 586 square miles) located north of the city of Richland, Washington, and the confluence of the Yakima and Columbia Rivers. Historically, the area of the Hanford Site has been reported as 1450 square kilometers (560 square miles), calculated by the addition of sections and subunits based on surveys from the 1800s. Included in the Hanford Site is 36.42 square kilometers (14.1 square miles) of Columbia River surface water and 2.6 square kilometers (1 square mile) of Washington State land (DOE/EIS-0222-F). Approximately $6 \%$ of the land area has been disturbed and is actively used.

The cities of Richland, Kennewick, and Pasco (known collectively as the Tri-Cities) constitute the nearest population center and are located southeast of the Hanford Site. Richland and Kennewick are in Benton County, and Pasco is in Franklin County. Land surrounding the Hanford Site is used for urban and industrial development, irrigated and dry land farming, and grazing. The estimated 2000 populations of the Tri-Cities were Richland 39,350, Pasco 33,010, and Kennewick 55,780. The combined populations of three smaller outlying communities of the Tri-Cities (Benton City, Prosser, and West Richland) totaled 16,320 in 2000 (P.L. 94-171). In 2000, population totals for Benton and Franklin Counties were estimated at 142,475 and 49,347 , respectively. 


\subsection{Site Description}

The major operational areas at the Hanford Site include the following sites:

- The 100 Areas (on the south shore of the Columbia River) are the sites of nine retired plutonium production reactors, including the dual-purpose N Reactor. The 100 Areas occupy approximately 11 square kilometers (4 square miles).

- The 200 West and 200 East Areas are located within the Central Plateau, approximately 8 and 11 kilometers (5 and 7 miles), respectively, south of the Columbia River. Historically, these areas have been dedicated to fuel reprocessing and waste processing management and disposal activities. The 200 Areas cover approximately 16 square kilometers (6 square miles).

- The 300 Area, located just north of the city of Richland, contained fuel fabrication facilities and is currently the site of nuclear research and development. This area covers 1.5 square kilometers (0.6 square mile).

- The 400 Area is approximately 8 kilometers (5 miles) northwest of the 300 Area. The 400 Area contains the site of the Fast Flux Test Facility used in the testing of breeder reactor systems. Also included in this area is the Fuels and Materials Examination Facility.

- The 600 Area includes all of the Hanford Site not occupied by the 100, 200, 300, and 400 areas.

- The former 1100 Area (now called Richland North) is located south of the Hanford Site in the northern portion of the city of Richland. This is a support area that includes general stores, transportation maintenance, and the DOE and DOE contractor facilities.

During 1996, the 3000 Area was cleaned up. All land and facilities within the area were turned over to the Port of Benton, and the 3000 Area designation was retired (PNNL-11472).

In addition, a portion of the site has been designated as the Hanford Reach National Monument (65 FR 37253). Established on June 9, 2000, the monument totals 792.6 square kilometers (306 square miles) and includes the Fitzner Eberhardt Arid Lands Ecology Reserve, Saddle Mountain Wildlife Refuge, McGee Ranch/Riverlands Area, and land 1/4 mile inland from the mean high-water mark on the south and west shores of the 82-kilometer) 51-mile long Hanford Reach--the last free-flowing, non-tidal stretch of the Columbia River. It also includes Wahluke Slope, federally owned islands in the Hanford Reach, White Bluffs, and the sand dune area northwest of the Energy Northwest Site (Figure 1.1). This designation establishes the protection and management of the lands within the region of the monument. By memorandum, the President also directed the Secretary of Energy to consult with the Secretary of the Interior regarding the incorporation of additional Hanford Site lands into the monument as the land is remediated.

Non-DOE activities on Hanford Site leased land include commercial power production on the land occupied by the Energy Northwest WNP-2 plant, partially completed WNP-1 and WNP-4 plants, and operation of a commercial low-level waste burial site by US Ecology, Inc. Immediately adjacent to the southern boundary of the Hanford Site, Framatome ANP, Richland Inc. operates a commercial nuclear fuel fabrication facility, and Allied Technology Group Corporation operates a low-level waste decontamination, super compaction, and packaging disposal facility. The Laser Interferometer Gravitational-Wave Observatory is located between the 200 and 400 Areas.

To reach agreement on the basic assumptions for the cleanup and closure of waste sites on the Central Plateau, DOE, the U.S. Environmental Protection Agency (EPA), and the Washington State Department 
of Ecology (Ecology) - the Tri-Parties - initiated the development of the Central Plateau Risk Framework $^{1}$ at a series of workshops attended by Central Plateau program as well as Tri-Party representatives in October 2001.

One result of the workshops was agreement on a Core Zone (Figure 1.1) that includes the 200 East Area, the 200 West Area, ERDF, the commercial low-level radioactive waste disposal facility operated by US Ecology, the BC cribs and trenches, the main B Pond, and the S Ponds. Along with agreement on the Core Zone, the Tri-Parties are developing a strategy for closure of the Central Plateau, dividing the plateau into 24 regions. Each of the regions will be managed as a specific closure project with Central Plateau facilities, waste sites, and structures cleaned up by 2035. Two potential exceptions to the 2035 closure date are final closure of commercial low-level waste and the graphite cores of the production reactors.

Much of the Hanford Site description and historical site operation information presented here was taken from the introduction to the Hanford Site Environmental Report for Calendar Year 2001 (PNNL-13910). More detailed information on the Hanford Site environment is provided by Neitzel et al.

(PNL-6415 Rev 14).

\subsection{Historical Site Operations}

From its creation in 1943 until recently, Hanford Site facilities were dedicated primarily to the production of weapons-grade plutonium for national defense (Gephart and Lundgren 1998, DOE/EM-0319). The current missions of the Hanford Site are to safely clean up and manage the Hanford Site legacy waste and to develop and deploy science and technology (DOE/RL-96-92). During its nearly 40-year mission to produce special nuclear materials, the Hanford Site has:

- Fabricated reactor fuel (300 Area)

- Performed research and development (300 Area)

- Operated nine production reactors (100 Areas)

- Operated five chemical separation facilities (200 Areas)

- Fabricated plutonium components for nuclear weapons (200 West Area)

\subsection{Performance Objectives}

The performance objectives of the 2004 Composite Analysis are to

- Estimate the combined radionuclide releases to groundwater, surface water, and air from multiple sources, and, based on those estimates,

- Estimate the potential cumulative dose to a hypothetical future member of the public from radionuclides associated with waste disposal sites at the Hanford Site.

\footnotetext{
${ }^{1}$ Klein, KA, DR Einan, and MA Wilson. 2002. Consensus Advice \#132: Exposure Scenarios Task Force on the 200 Area. Letter from Tri-Party Agencies (Manager U.S. Department of Energy Richland Operations Office Keith A. Klein, U.S. Environmental Protection Agency Acting Hanford Project Manager David R. Einan, State of Washington Department of Ecology Program Manager Michael A. Wilson) to Hanford Advisory Board Chair Todd Martin, July 11, 2002, Tri-Party Agencies, Richland, Washington.
} 
DOE Order 5400.5 sets the DOE primary dose limit per year to members of the public at 100 millirem and the constraint dose at 30 millirem.

If the projected total dose to a member of the public from all pathways is over 100 millirem in a year, DOE will alter its waste disposal plan. If the projected dose is over 30 millirem in a year, DOE will determine whether a different economically viable approach to waste disposal will lead to substantially lower doses. In both cases, DOE will use an options analysis and ALARA assessment to evaluate possible alternate remedial actions to reduce the estimated dose.

\subsection{Data Quality Objective Process}

DOE Manual 435.1-1 requires the use of the data quality objective (DQO) process (EPA/600/R-96/055) or a comparable process in the planning of a composite analysis. The objectives of applying a structured process such as the DQO process are to:

- Manage and control the risk of making incorrect decisions

- Determine the data required to support making specific decisions

- Determine the type and quality of required data

- Allow stakeholders, decision makers, data users, and relevant technical experts to participate in planning and assessment

- Determine the quantity, location, and type of samples required

- Quantify the uncertainty in data through development of statistical sampling plans

- Reduce overall cost by identifying resource-efficient sample collection and analytical methods by optimizing the sample and analysis plans

The key benefits of the DQO process are it: 1) gathers input from clients, regulators, and stakeholders in an organized and effective manner, 2) obtains buy-in from pertinent groups, 3) helps document the entire process (global issues and assumptions), and 4) provides a systematic process to focus a study on its requirements (defined by DQO teams)

The standard 7-step DQO process (EPA/600/R-96/055) was developed for data sampling programs, with the 7 steps being:

- Step 1: State the Problem

- Step 2: Identify Decisions

- Step 3: Identify Inputs for Analysis

- Step 4: Specify Boundaries of Analysis

- Step 5: Define Decision Rules

- Step 6: Specify Error Tolerances on Decision Rules

- Step 7: Optimize Analysis Design

The first 5 steps of the DQO process work well for developing the scope of the 2004 Composite Analysis. Steps 6, and 7 are very important when developing a sampling plan but are not applicable when planning a Composite Analysis. 
Step 5 of the DQO involves the formulation of "decision rules" while Step 2 identifies decisions. DOE Order 435.1 prescribes both the decision (Step 2) and identifies the metrics to be used in the decision rule (Step 5). For this document, these two steps will be combined and presented under Step 2.

Step 6 deals with the "specific limits of the decision error" and is geared towards sampling error issues (Type 1 and Type 2 errors) associated with characterization and sampling data plans. The 2004

Composite Analysis will not include sampling plans specifically, but it will include characterization data from other studies and may influence their sampling plans.

Step 7 entails the "optimization of the design for obtaining data." Again, this step does not fit the primary purpose of the Composite Analysis, which is an assessment and not a sampling effort. 


\subsection{Composite Analysis Scope}

The modified DQO process described in Section 1.7 was used to focus the scope of the 2004 Composite Analysis by defining the problem, identifying decisions and key data, specifying the boundaries of the analysis, and defining the decision rules and how the 2004 Composite Analysis will support the understanding of the overall results. The results of the DQO process are presented in the Appendix. Elements defining the scope of the assessment are summarized in this section.

\subsection{Geographic Boundaries}

Geographic boundaries of the 2004 Composite Analysis for the surface and subsurface water pathways extend across the Hanford Site from Rattlesnake Mountain to the Columbia River and include the Columbia River from Vernita Bridge to the City of Richland. Where the boundary of the Hanford Site coincides with the Columbia River, the boundary is the high water mark of the river. Future Hanford Site boundaries are expected to retract to the Core Zone where facilities are expected to remain for some time to manage the remaining waste at the Hanford Site. It is also anticipated that groundwater in this area will be precluded from use. The initial assessment (PNNL-14027) performed with the System Assessment Capability (SAC) tool used McNary Dam as its downstream boundary. That initial assessment and the solid waste environmental impact statement (DOE/EIS-0286D2) have shown in the future the concentration of contaminants downstream of Richland are estimated to be less than at Richland. The 2004 Composite Analysis will therefore use the confluence of the Yakima and Columbia Rivers at the city of Richland as its downstream boundary.

Geographic boundaries of the 2004 Composite Analysis for the air pathway are a northern boundary that runs west to east through the Saddle Mountains and the community of Othello. The southern boundary passes just south of the community of Umatilla and McNary Dam. The eastern boundary runs northsouth through the community of Wallula near the confluence of the Columbia and Walla Walla Rivers. The western boundary runs north-south just west of the community of Grandview and Priest Rapids Dam.

\subsection{Waste Sites and Facilities}

Within the spatial boundaries of the assessment, it is necessary to clearly define the population of disposal waste sites. The Waste Information Data System (WIDS) database showed 2730 waste sites at the Hanford Site in January 2003. Of these 2730 waste sites and several future waste sites (for example, the Integrated Disposal Facility), 1046 sites were identified for consideration in the 2004 Composite Analysis. Several screens were applied to the WIDS list of waste sites to identify those to be included in the 2004 Composite Analysis. Waste sites were screened out that were 1) initially misclassified as waste sites, 2) not representing releases to the environment, 3) receiving waste streams categorized as nonradioactive or non-hazardous chemical waste streams, 4) not including key waste contaminants, and 5) duplicate sites.

The bulk of the 1046 waste sites are located within the 100, 200, and 300 Areas. However, some waste was discharged or disposed outside of these operational areas (for example, the Gable Mountain Pond, the waste disposal caissons located adjacent to the Energy Northwest property, the 300 North burial grounds, and ERDF-located between 200 West and 200 East Areas). The Hanford Site also includes a 
commercial low-level waste disposal site operated by US Ecology Inc. that is located southwest of the 200 East Area. Table A.18 in the Appendix summarizes the screening process and number of sites to be included in the 2004 Composite Analysis.

The Composite Analysis activity relies on many programs at the Hanford Site to provide information needed for the assessment. Among the most important of these are the assessment programs supporting the tank farms, the solid waste burial grounds, the immobilized low-activity waste disposal facilities, and ERDF. In addition, two inventory models are being applied at the Hanford Site: the Hanford Soil Inventory Model (SIM) for crib discharges and selected unplanned releases and the Hanford Tank Waste Operation Simulator (HTWOS) model for the movement of tank waste and its transformation into final waste forms at final disposal locations. Both of these models are fundamental to assembling an overall inventory database for Hanford waste sites.

\subsection{Contaminants}

The contaminants to be included in the 2004 Composite Analysis were selected through the DQO process presented in the Appendix. Two key considerations formed the basis for the selection process:

- What contaminants have been observed in the environment and have the potential to impact human or ecological health?

- What contaminants have sufficient inventory in waste sites and have the potential to impact human and/or ecological health as indicated through previous assessments?

The screening process used to select the contaminants for the 2004 Composite Analysis (see Table 2.1) included the following steps:

- Reviewed all groundwater monitoring data from 1990 to December 2002

- Retained all sample results above detection levels

- Retained all samples not rejected by data quality assurance checks

- Retained all radionuclides with a half-life greater than 10 years

- Identified all samples above drinking water standards

- Identified all radionuclides that have regional or site-wide distribution (spatial distribution criteria represent more than one or two points in the aquifer)

- Identified all radionuclides that represent a current issue and not a single moment in time observation (temporal distribution criteria)

- Incorporated radionuclides that may have a future impact as indicated by performance assessments and environmental impact statement studies 
Table 2.1. List of Contaminants of Concern for Groundwater, Surface Water, and Air Exposure Pathways to Be Included in the 2004 Composite Analysis

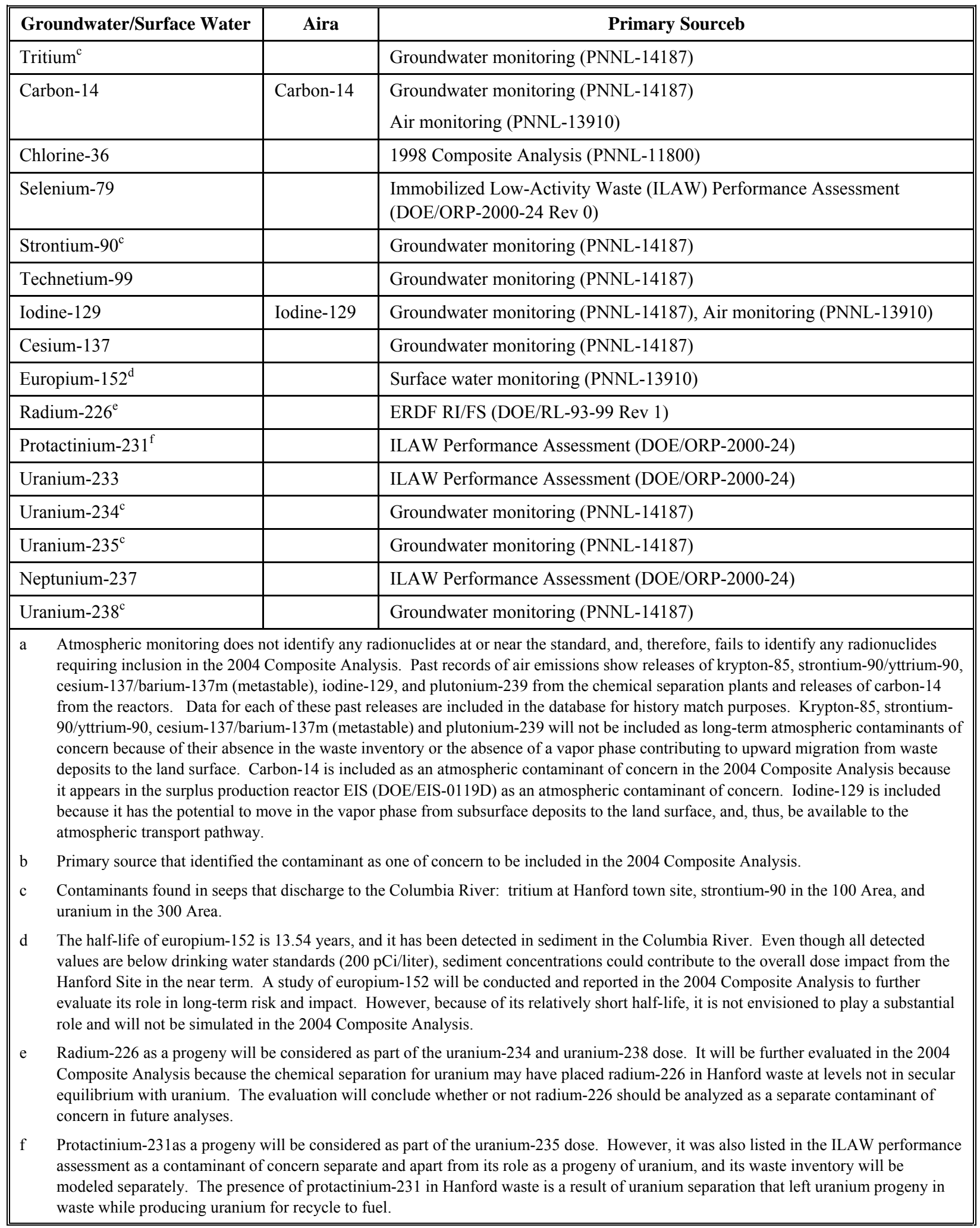




\subsection{Past and Planned Waste Management Activities}

To perform the Composite Analysis, a description of past waste management activities and a set of assumptions about future disposal activities and site cleanup actions (end states) must be developed. Historic records on waste disposal, unplanned releases, and facility operation have been assembled to obtain the information needed to represent past actions. A key resource for this effort is WIDS. The WIDS site list as of January 2003 was used to define an initial list of the radioactive waste disposal sites of interest for this study. Hanford's multiyear work plans and other site planning documents provide a set of assumptions regarding the disposal locations, remedial actions, recovery and treatment efficiencies, etc., that define the end state of the Hanford Site.

\subsubsection{Areas}

Waste within the 100 Areas include spent fuel in K Basins, surplus facilities including the graphite cores of the production reactors, miscellaneous underground storage tanks, liquid discharge sites, and solid waste burial grounds. Additional waste sources are discharges sent directly to the Columbia River from cooling water retention basins and contaminant plumes in the groundwater created by liquid discharges. The spent fuel will be removed from the 100 Areas and stabilized and packaged for eventual disposal off-site in a national repository. With the exception of cocooned graphite cores of the production reactors, cleanup of the 100 Areas to will be complete by 2012. Surplus facilities will be removed from the 100 Areas with the notable exception of the B Reactor that has been declared a national historic monument. Contaminated soil from liquid discharge sites will be removed to a depth of 15 feet below grade, and all solid waste will be removed. With the exception of the graphite cores, which will have their own disposal trench, debris from surplus facilities, soil from liquid discharge sites, and solid waste will be disposed in the ERDF trench in the Core Zone. Additional data on specific 100 Area waste are shown in the Appendix.

\subsubsection{0/400/600 Areas}

Waste within these areas is similar to those in the 100 Areas with the exception of the spent fuel in $\mathrm{K}$ Basins and the graphite cores of the production reactors. Waste in the 300/400/600 areas includes some spent fuel and nuclear materials, surplus contaminated facilities including research reactors, liquid discharge sites, and solid waste burial grounds. Spent fuel within these areas includes the light water reactor, Test Reactor and Isotope Production General Atomics, and Fast Flux Test Facility fuel, which is stored in the 400 Area until storage is available in the 200 Areas. Other special nuclear materials include uranium stored for the interim in the 400 Area, nuclear materials in the 324/327 buildings including some tank waste, the 300 Area fuel supply, the inventory of unirradiated uranium, and a few cesium-137 and strontium-90 capsules and isotopic heat sources stored in the 324 Building. All non-essential, surplus buildings and facilities without a post-cleanup use will be removed. All liquid discharge sites and solid waste burial grounds associated with the 300 Area will undergo remedial actions similar to those undertaken in the 100 Areas. Debris from CERCLA remedial actions from these areas will be disposed in the ERDF trench in the Core Zone. Additional data on specific waste in the 300/400/600 areas are shown in the Appendix. With the exception of the 618-10 and 618-11 waste sites, the 300/400/600 area waste sites are scheduled to be cleaned up by 2012. The 618-10 and 618-11 waste sites have been transferred to the Central Plateau contractor and completion of remedial action is scheduled for 2018. 


\subsubsection{Central Plateau}

Waste within the Central Plateau includes spent fuel; other special nuclear materials including Plutonium Finishing Plant material, cesium-137 and strontium-90 capsules; surplus facilities including chemical separations plants and tunnels; single- and double-shell tank waste; liquid discharge sites; unplanned release sites; and solid waste burial grounds. The Central Plateau area includes the $200 \mathrm{West}$ and 200 East Areas, the commercial low-level waste disposal facility operated by US Ecology Inc., the ERDF trench, and the BC cribs and trenches that are located south of the 200 East Area and east of the US Ecology Inc. site. Virtually all of the radioactive and chemical waste generated during Hanford operations that will remain at the Hanford Site will be disposed within the Core Zone.

Spent fuel, special nuclear materials, immobilized high-level waste, and post-1970 transuranic waste will be transported off-site prior to site closure. Tank waste will be retrieved, separated into high-level and low-activity fractions, and solidified. The low-activity fraction will be disposed on-site, and the highlevel fraction will be disposed off-site. Secondary waste from these activities will be disposed of as solid waste on site. Remedial actions for past tank leaks, future tank losses, and tank waste residuals will be limited to in-place stabilization and the placement of surface barriers. It is assumed that similar remedial actions will be taken for all liquid discharge sites, unplanned release sites, and solid waste burial grounds within the Central Plateau.

All non-essential, surplus buildings and facilities without a post-cleanup use will undergo decontamination and decommissioning. These will include all chemical separations buildings and the Plutonium Finishing Plant. Debris from those that can be removed will be disposed in the ERDF trench. The ERDF trench and the trench that receives the graphite cores of the production reactors will receive a protective surface barrier when closed. Some facilities including the chemical separations buildings and PUREX tunnels will be stabilized in place and covered with a protective surface barrier. Simulations for the 2004 Composite Analysis will be performed without taking credit for contaminant reduction in groundwater through the use of pump and treat remediation. Additional data on specific Central Plateau waste are shown in the Appendix. Central Plateau cleanup of past practice sites is scheduled to be completed by 2024, while tank farms and associated facilities will be remediated and closed by 2035 .

\subsection{Future Land Use Assumptions}

Assumptions about future land use must be made to develop appropriate exposure scenarios for the assessment. The final Hanford Comprehensive Land Use Plan (CLUP) EIS (64 FR 61615) presents a preferred alternative for land use for the entire Hanford Site. However, while the CLUP EIS has taken into account the stated values of the public, it focuses on DOE's role as care taker for the next 50 years. Accordingly, the land uses identified do not translate into unambiguous remedial actions or cleanup standards. For example, the EIS indicates the Columbia River Corridor will not be devoted to residential land use. Rather, it will be devoted to a combination of recreation and preservation with the largest portion designated to protect cultural and ecological resources.

The CLUP EIS (64 FR 61615) indicates the planned remedial actions for the 300/400/600 Areas should permit continued use of a portion of the site including the 300 Area, 400 Area, and the Energy Northwest site for industry. Lands west of State Highway 240 to Vernita Bridge including the Arid Lands Ecology 
Reserve, the McGee Ranch and Umtanum Ridge, and lands north of the Columbia River will be designated preservation. The remainder of the 600 Area would be designed conservation to support a possible Bureau of Land Management mission for multiple users including mining.

The CLUP EIS (64 FR 61615) indicates that future land use in the Core Zone will be limited to a combination of industry and waste management activities.

\subsection{Temporal Resolution}

The regulatory time period of the assessment will extend from 1944 through 3035 inclusive and will include the 1000 years following the assumed Hanford Site closure date of 2035 as required by DOE Order 435.1. Several analyses within the Composite Analysis will examine a 10,000-year post-closure period to evaluate peak releases. Thus, some simulations will extend from 1944 until 12035. Two potential exceptions to the 2035 closure date are final closure of commercial low-level waste site and the final movement and burial of the graphite cores of the production reactors. Resolution of releases to the environment from 1944 to the present will be at most annual and at least 5-year intervals to ensure temporal realism and to support history matching efforts based on estimates of mass in the aquifer indicated by monitoring data. During the period from present day until site closure, the temporal resolution of releases will be the same to ensure a realistic representation of disposal and facility decontamination and decommissioning. Thereafter, the temporal resolution will be sufficient to support the risk and impact assessment. Use of annual average or coarser values of time from a groundwater or river simulation will be supplemented with empirical data to estimate seasonal variations in water quality. 


\subsection{Technical Approach for Performance of the Composite Analysis}

The 2004 Composite Analysis will include a 10,000-year median-value deterministic simulation of all analytes, a 1,000-year stochastic analysis of all analytes, no more than 10 sensitivity cases simulated as deterministic cases, and a 10,000-year stochastic analysis of select key contaminants (e.g., technetium-99, iodine-129, uranium-233/234/235/238). Sensitivity analyses will be used to identify parameters having the greatest influence on contaminant concentration in the environment and risk or impact. They will also be used to evaluate management alternatives and assess the impact of changes to the baseline simulated after the assessment was initiated.

The key attributes and endpoints for each technical element within the analysis are presented in this section. SAC (BHI-01365, PNNL-14027, PNNL-13932 Vols 1 and 2) will be used for the 2004 Composite Analysis and is briefly described here. The process of incorporating information from other related analyses at the Hanford Site will be discussed along with the major assumptions and limitations of the 2004 Composite Analysis.

\subsection{Planned Analysis}

Key attributes of each analysis module are described in the following section to provide an understanding of how each aspect of the computation will be evaluated.

\subsubsection{Inventory}

\section{Key Attributes}

A. Inventory for specific waste disposal and storage locations for the period from 1944 to the present will be based on disposal records, process knowledge, and tank and field sample results. The inventory for the 2004 Composite Analysis will merge data from records with results from SIM (BHI-01496) and estimates of tank waste movement and disposal from the HTWOS model (HNF-SD-WM-SP-012).

B. Where available, the inventory of disposed waste and its uncertainty for the period 1944 to the present will be developed in as much detail as is available (such as including the inventory for specific liquid discharge sites and solid waste sites, and cataloging facilities individually if records exist).

C. Inventory for specific waste disposal and storage locations from the present time to site closure in 2035 will be based on the assumptions for waste retrieval and treatment, waste remedial action, waste disposal, etc., captured in the Hanford Site Disposition Baseline (HSDB) and waste disposal forecasts. Where possible, the assumptions will be applied to entire classes of waste or waste forms. For example, all liquid discharge sites in the 100 and 300 Areas will be excavated to 4.5 meters (15 feet) below grade with all excavated materials transported to and disposed in the ERDF trench.

D. The total and site-specific radionuclide inventory and its uncertainty will be developed for each of the radionuclides to be simulated. 
E. Perturbations to HSDB assumptions for waste retrieval and treatment will be examined in the 2004 Composite Analysis to explore the sensitivity of the analysis to waste forms and final disposal alternatives.

\section{Endpoints for Analysis}

A. The Inventory Module will provide estimates of the volume and mass of contaminant as a function of time. The estimates will address inventory delivered to each release model:

1. Delivered directly to environment, for example, discharges to cribs, ponds, trenches, reverse wells

2. Disposed in specific waste forms, for example, in solid waste burial grounds, ILAW sites

3. Retained in facilities

4. Discharged to the Columbia River

5. Emitted to the atmosphere

If possible, the time interval will be annual. If the release estimate relies on process knowledge and simulations of waste discharge, the time interval may be a function of the SIM and HTWOS models and, therefore, be constrained to a different interval. These estimates will reflect the history and forecast of disposals from 1944 through site closure in 2035.

B. The waste disposal is assumed complete at the time of site closure and the inventory in the environment unchanged except by release to the environment from waste forms and migration within the environment. Two waste forms are scheduled for disposal after 2035. The graphite cores of the production reactors are not scheduled for one-piece removal from the 100 Areas to the Central Plateau until approximately 2067. Currently, the Hanford Site is scheduled to receive waste from other DOE sites through 2046; therefore, solid waste burials continue until then. In addition, the commercial low-level radioactive waste disposal facility operated by US Ecology will receive waste until 2056.

\subsubsection{Contaminant Release for Waste Sites and Facilities}

\section{Key Attributes}

A. Release simulations will produce the estimated annual release to the vadose zone from the variety of waste sites identified according to the final disposition indicated in the HSDB. To support simulation of all releases, the following information is required to supplement the inventory:

1. Physical location (coordinates) of the disposal or discharge facility.

2. Bottom elevation of disposal or discharge facility.

3. Area of the facility (such as the areal footprint of cribs, specific retention trenches, etc.).

4. Start and end dates of waste disposal and any duration of waste disposal or contaminant release information; in some cases, including tank waste residuals, only a start date is required.

5. Leak/loss date and duration for unplanned releases or begin date for release to the environment.

6. Remedial action to be performed, including the type of surface barrier and its design performance (for example, net infiltration rate, design life, degradation time line).

7. Begin/end dates of remedial action, including the placement date of a surface barrier.

B. Some releases are simple pass-through steps from "inventory" to "vadose zone" or "inventory" to "Columbia River" (for example, liquid discharges to cribs, unplanned liquid releases from tanks and piping, coolant discharges to the Columbia River and stack emissions to the atmosphere). 
C. Solid waste burial grounds, the ERDF trench, and debris from the demolition of facilities will be simulated using a soil debris release model that includes dissolution, desorption, and leachability processes. The following additional information is required:

1. Soil-debris release model data

2. Area and thickness of facility or waste deposit (such as, the areal footprint of waste and the thickness of the waste)

D. Waste encased in a cement product (for example, concrete, grout) will be simulated using a concrete release model that has the capability of diffusion, dissolution, or leaching processes. Such a model was applied to simulate waste disposed in concrete high integrity containers used to dispose of some low-level radioactive waste. The following additional information is required:

1. Cement release model data

2. Surface area to volume ratio typical of the cemented waste form

3. Area and thickness of facility or waste (such as, the areal footprint of waste and the thickness of the waste)

E. Residual tank waste will be simulated using a salt cake dissolution model based on nitrate salt dissolution and congruent release of other contaminants because it is the current available model. However, best estimate or median value simulations will rely on "release-to-water table" files provided by the Tank Farm Contractor. The following additional information is required:

1. Salt-cake release model data

2. Area and thickness of tank farm waste (such as, the areal footprint of waste and the thickness of the waste)

3. Best-estimate or median-value release-to-water table files

F. Releases from the graphite cores of production reactors will be simulated using the release model developed for the surplus production reactor EIS. The following additional information is required:

1. Graphite core release model data (DOE/EIS-0119D, DOE/EIS-0119F)

2. Area and thickness of graphite core waste (such as, the areal footprint of waste and the thickness of the waste)

G. Releases from ILAW glass will be simulated using a simplified glass corrosion and release model based in part on the reactive geochemistry and transport model applied within the ILAW performance assessment. Within the River Protection Program, the ILAW release is currently estimated using a fully coupled, reactive, geochemistry and vadose zone transport model. Composite Analysis best estimate or median value simulations will rely on "release-to-water table" files provided by the Tank Farm Contractor. The following additional information is required:

1. ILAW release model data and/or ILAW release forecast(s)

2. Bottom elevation of disposal trenches or excavation (or a lower elevation such as the elevation of the plane in the vadose zone where the ILAW project will specify the released mass flux)

3. Area and thickness of the glass waste form deposit (such as, the areal footprint of waste and the thickness of the waste)

4. Best-estimate or median-value release-to-water table files

Additional information about the disposal is needed for the calculation. This information includes the begin date of ILAW glass disposal to the environment, the type of interim and final surface barrier(s) to be applied and its design performance, and the end date of disposal, including the placement date of surface barrier(s). If alternate waste forms are to be evaluated or adopted for ILAW, their release mechanisms must be specified in terms of release models encoded within SAC and performance data made available by September 30, 2003. 
H. Releases from naval reactor compartments will be simulated using the release model applied in the performance assessment for the post-1988 solid waste burial grounds in the 200 East Area

(WHC-SD-WM-TI-730). Essentially, the reactor compartments are a solid waste disposal. The following additional information has been acquired from the U.S. Navy:

1. Naval reactor compartment corrosion and release model data

2. Area and thickness of reactor compartment deposit (such as, the areal footprint of waste and the thickness of the waste)

I. There will be a realization of release model parameters corresponding to each of the 100 realizations of inventory.

\section{Endpoints for Analysis}

A. The Release Module will provide estimates of the volume and mass of contaminant as a function of time that is released from various waste types to the environment. The estimates will address inventory:

1. Delivered to the vadose zone (for example, discharges to cribs, ponds, trenches, reverse wells)

2. Disposed in specific waste forms (for example, in solid waste burial grounds, ILAW, naval reactor compartments)

3. Retained in facilities (for example, chemical separations plants and tunnels)

In addition to direct discharges to the vadose zone, other pass through releases include those to the Columbia River and to the atmosphere. Data on these inventories will be tracked through the release model to simply indicate their final disposal. If possible, the time interval will be annual. If the release estimate relies on process knowledge and simulations of waste discharges, the time interval may be a function of Hanford Defined Waste model (LA-UR-96-3860), SIM (BHI-01496), and HT WOS model (HNF-SD-WM-SP-012) simulations. These release estimates will reflect the history and forecast of disposals from 1944 through site closure in 2035 and the following 1000 years until 3035 . Some analyses will forecast release for a 10,000 year post closure period.

B. In some cases, the releases are assumed to occur from the time of disposal. In other cases, the releases are assumed to occur following degradation of a container, structure, or barrier. Which assumption is used depends on whether the waste disposal is assigned a period of time during which container corrosion occurs. Being short relative to the 1000 -year or longer regulatory analysis period, the corrosion period is often neglected. Releases are assumed to continue until the waste form is exhausted or until the endpoint of the analysis (either 1000 or 10,000 years after site closure).

C. Because remedial actions can and will occur at past practice sites, the cumulative release during simulation will not be a continuously increasing function. For example, remedial actions at 100 Areas and 300 Area liquid discharge sites and solid waste burial grounds will result in the removal of waste from the environment and its reintroduction at the ERDF trench. Thus, simulating cumulative release to the environment in the 100 and 300 areas would show a sudden decrease following remedial action, while simulation of the release to the environment at the ERDF trench would show continued increase. 


\subsubsection{Atmospheric Transport}

\section{Key Attributes}

A. The Atmospheric Transport Module will use a modified version of an existing code, RATCHET (PNWD-2224 HEDR). The code incorporates the approach for calculating mixing-layer thickness that is used in the RASCAL code (NUREG-1741). The code was developed and is maintained by the Pacific Northwest National Laboratory.

B. The computer code implements a Lagrangian-trajectory, Gaussian-puff dispersion model to simulate transport of contaminants in the atmosphere. Sequences of Gaussian-puffs represent plumes released from ground-level or elevated sources (stacks). Transport, diffusion, and deposition of material in the puffs are controlled by wind, atmospheric stability, precipitation, and mixing-layer depth fields.

C. The atmospheric model assumes that releases to the atmosphere are long-term releases because SAC operates in annual time steps. The model simulates transport for a time period of 1 year using daily meteorological data for that year.

D. Long term climate changes are not accounted for in the atmospheric transport model. Stochastic variability is handled by random sampling of the existing yearly meteorological data sets to represent the current and future meteorological conditions for a given year.

E. The atmospheric model simulates a unit release for all possible source locations. Release locations are mapped to the nearest model node. The results are then multiplied by the release rates provided by the INVENTORY and VADOSE zone models.

\section{Endpoints for Analysis}

A. The atmospheric transport model will provide yearly release rates of contaminants to the air and deposition rates of airborne contaminants to the soil for the entire model domain and for each analyte class (particle, noble gas, and iodine).

B. Deposition rates to the soil calculated by the atmospheric transport model will be used as input to the SOIL model.

C. The model domain for the atmospheric transport model extends south just beyond Irrigon, Oregon, west just beyond Grandview, Washington, east to Wallula and north to Othello. The center of the model domain is located just south of the horn of the Yakima River.

\subsubsection{Vadose Zone Flow and Transport}

\section{Key Attributes}

A. Vadose zone flow and transport simulations will be based on

1. Geohydrologic profiles and properties for areas of the Hanford Site (such as, portions of the 200 Areas, each 100 Area, the 300 Area)

2. Estimates of deep infiltration rates that drive contaminant migration

3. Estimates of geochemical reaction of contaminants in contact with the soil and sediment of the vadose zone profile

4. Waste inventory and release projections 
B. Geohydrologic profile and hydraulic and transport property data will be assembled for each of several areas assumed to have similar geohydrologic structure and properties. For this discussion, these areas are termed hydrogeologic provinces. The vadose zone profile and property models will be based on one-dimensional vertical columns and/or two-dimensional cross sections. While the 2004 Composite Analysis will in general use a one-dimensional vadose zone model, this analysis may explore the use of multidimensional models that explicitly account for structural features occurring at the Hanford Site. The current one-dimensional approach will consider uncertainty in the model parameters. Geohydrologic units will be identified and their thickness ranges specified for each hydrogeologic province. The range for each process model parameter will also be developed for each geohydrologic unit of the hydrogeologic province. Properties that will be represented include unsaturated hydraulic conductivity, porosity, water retention parameters, dispersivity, and diffusion coefficient. Care will be taken to develop and apply correlated model parameters, where necessary, to appropriately model properties (for example, parameters of the van Genuchten and Mualem models - van Genuchten 1980) of unsaturated hydraulics and water retention). Data to support the vadose zone profile and property models will be assembled for each hydrogeologic province.

C. Infiltration rates into the waste deposits in the vadose zone are a function of the climate, the surface soil, and the vegetation. Estimates of infiltration and water table elevation for the 2004 Composite Analysis are dependent on the assumption of a continuation of current climate, as indicated by the available Hanford Site climate record (approximately 41 years of record are available). Vadose zone simulations will incorporate infiltration by applying a step model of sequential infiltration events for defined periods of time. Simulations will begin with a natural recharge rate defined by the climate, the undisturbed soil profile, and original vegetation. This will be followed by an operational period when the land surface is disturbed (for example, trenches excavated, cribs constructed, waste disposed and buried) and maintained free of vegetation. Should a barrier be specified for a waste site in the disposition baseline, a protective barrier period begins with construction of a surface barrier and lasts for the design life of the barrier. Finally, the degraded cover period begins after the design life of a barrier is exceeded and lasts for the period of time equivalent to the design life of the barrier, during which recharge increases in piecewise constant steps from the barrier period rate to the pre1944 natural recharge rate, where it remains thereafter. Thus, infiltration will be simulated using a series of infiltration rates, including natural, operational (first and second type), protective barrier, and degraded barrier, and finally returning to natural. Several protective barrier designs are being considered at the Hanford Site. Data to support the vadose zone infiltration boundary condition will be assembled.

D. The adsorption of contaminants with vadose zone sediment will be approximated using the linear sorption isotherm model. The mobility of contamination is highly dependent upon its speciation and surrounding environment. It is assumed that upon introduction to the vadose zone environment, waste mobility is dominated by waste characteristics. After being in contact with vadose zone sediment and soil water for some distance, it is assumed the waste undergoes a change in its mobility based on buffering of the contaminant solution by the vadose zone hydrogeologic units. Finally, it is assumed once contaminants have migrated a short distance in the Hanford Site unconfined aquifer, another mobility state is defined by the highly buffered, neutralized, and diluted contaminant. Distribution coefficients will be defined for each contaminant in several zones; for example, upper (near field) vadose zone, lower (far field) vadose zone, and unconfined aquifer. Where indicated, $\mathrm{K}_{\mathrm{d}}$ dependency on hydrogeologic units will be included. Broad ranges of distribution coefficient may be necessary to represent the suite of waste speciation and surrounding environment conditions that are possible. Data to support the vadose zone and aquifer geochemical reaction model will be assembled. 
E. Analysis of liquid discharge and unplanned release sites will be conducted on a site-by-site basis whenever inventory and release data permit. This is because the superposition of liquid discharges to a single soil column results in non-representative contaminant migration and release from the vadose zone. In those cases where liquid discharge sites are remediated, contamination to a prescribed elevation will be removed from the vadose zone simulation and placed in the ERDF trench. The vadose zone simulation will continue to predict the migration and fate of contamination in the vadose zone below the cleanup elevation.

F. Solid waste burial grounds will be simulated at the burial ground scale; for example, trenches will be aggregated to the scale of a burial ground. The inventory of solid waste disposal will be increased over time until all burial grounds are closed. In some cases, the simulation will account for remedial action, and, in those cases, fractions of the solid waste inventory will be removed during the remedial action time period. The vadose zone simulation will continue to predict the migration and fate of contamination in the vadose zone below the cleanup elevation.

\section{Endpoints for Analysis}

A. The Vadose Zone Module will provide estimates of the mass flux of contaminant as a function of time entering the unconfined aquifer. The estimates will address releases from all operational areas for the radionuclide and chemical contaminants selected for the 2004 Composite Analysis. Released flux to the aquifer will be provided for individual waste sites and/or aggregations of waste sites where available (for example, liquid discharge sites), and for solid waste burial grounds where applicable (for example, the combination of trenches that comprise solid waste burial grounds). The vadose zone releases to the aquifer will be aggregated to groundwater model nodes in order to introduce contaminants into the aquifer model.

B. The Vadose Zone Module will provide estimates of mass flux of contaminants from the vadose zone to groundwater for the period of analysis.

\subsubsection{Groundwater Flow and Transport}

\section{Key Attributes}

A. The quantitative model used to estimate transport of contaminants through the groundwater pathway is based on a history of conceptual model development and numerical implementation documented in a series of reports PNL-8332, PNL-8971, PNL-10195, PNL-10886, and PNNL-11801. A complete description of the site-wide groundwater flow and transport model that will be used in the 2004 Composite Analysis is provided in recent work summarized in PNNL-13447, PNNL-13623, and PNNL-13641.

B. A transient inverse calibration method is being applied to create a model of the aquifer that is consistent with the entire body of water table elevation observations (observations from 1944 to the present). Alternate three-dimensional conceptual models are being developed and are based on the alternative interpretations of processes and structural features of the aquifer, such as hydraulic connection to the underlying basalts and to the Columbia River or the top and bottom elevations of major geohydrologic units.

C. Areal recharge from precipitation at the Hanford Site is highly variable, both spatially and temporally, and depends on local climate, soil type, and vegetation, as discussed in PNL-10285. Using their methodology, Fayer produced an estimate of the long-term average areal distribution of recharge resulting from the sitewide variation of the controlling features and parameters. The 
long-term average distribution of recharge used for the groundwater model is shown in the 1998 Composite Analysis (PNNL-11800), and described in PNNL-11801. This distribution is based on the available records of Hanford Site climate (approximately 41 years of records) and its application to the 2004 Composite Analysis is justified by the assumed continuation of the modernday climate.

D. The same groundwater model will be applied to simulate releases from the Central Plateau, the 300 Area, and the 100 Areas. However because of the scale of the 2004 Composite Analysis, the analysis will provide estimated releases to the Columbia River from each 100 Area by simulation of contaminant mass flux into groundwater without detailed simulation of dynamic groundwater mounds during the reactor operation period.

E. The adsorption of contaminants with groundwater sediment will be approximated using the linear sorption isotherm model. The methodology described in the vadose zone section above will be applied, and the development of model parameters will be done jointly with the vadose zone effort.

\section{Endpoints for Analysis}

A. The groundwater model will provide predictions of contaminant concentrations in space and mass and volumetric flux to the Columbia River. Both will be predicted as a function of time for the period of analysis. The groundwater prediction for the 2004 Composite Analysis will be for radionuclide contaminants. Chemical contaminants will be simulated as an additional effort to satisfy commitments to state and federal regulators of hazardous contaminants.

B. The groundwater model will provide estimates of contaminant concentrations that vary in time and space within the unconfined aquifer underlying the Hanford Site between the Core Zone in the Central Plateau and the Columbia River, and in the vicinity of the 100 and 300 Areas adjacent to the Columbia River. These concentrations will provide the basis for the estimated impact to human health and supplemental ecosystem risk.

\subsubsection{Columbia River Shore Environment}

\section{Key Attributes}

A. The River Shore Module will provide predictions of contaminant concentrations in the upper portion of the riparian zone (such as, seep water and its associated riparian zone soil). These will be based on predicted groundwater concentrations, predicted river water concentrations, solid-aqueous distribution coefficients, and empirical coefficients (dilution factors) that estimate relationships between groundwater and river water concentrations and those in the upper riparian zone media (such as, seep water and soil).

B. All river shore predictions are based on the fundamental assumption that regional climate and operation of the system of reservoirs on the Columbia River upstream of the Hanford Site continue throughout the period of analysis. Thus, the field observations that form the basis for the empirical coefficients apply throughout the period of analysis. 


\section{Endpoints for Analysis}

A. The River Shore Module treats the local setting defined by the near-shore groundwater and the neighboring riparian zone of the Columbia River. The River Shore Module relies on the Groundwater Module to provide groundwater contaminant concentrations, the Columbia River Module to provide river contaminant concentrations, and it produces local estimates of contaminant concentrations in seep water and adjacent soil within the upper portion of the riparian zone.

B. The River Shore Module will be able to provide predictions of seep water and associated soil concentrations at any point where groundwater contacts the Columbia River. Thus, the River Shore Module will provide predictions of contaminant concentrations at selected points on the shoreline of the Columbia River between Vernita Bridge and the city of Richland in the estimated impact to human health and supplemental ecosystem risk.

\subsubsection{Columbia River Flow and Transport}

\section{Key Attributes}

A. The analysis of Columbia River flow and transport for the period from 1944 to present with the River Module will be based on the record of Columbia River flow from 1944 to the present.

B. The period from present day until the endpoint of the analysis (either 1000 years or 10,000 years after closure) will be simulated for Columbia River flow and transport under the assumption that present day conditions of climate and river discharge continue throughout the period of interest. Hydrologic and climate records for both rivers and climate are recorded and made available to the public on a 30-year basis. Every decade the records are updated to reflect the most recent 30-year period. The existing 30-year record of regional climate and Columbia River discharge and stage will be used for the simulation.

C. The model of the Columbia River will include prediction of contaminants in river water both as dissolved phase and as suspended sediment in pore water within the riverbed and on river sediment, including gravel and cobble host environments for spawning salmon and other aquatic species.

D. The model of the Columbia River will be run twice: first, to calculate the contaminant concentration from background and non-Hanford contributions, and, second, to calculate the contaminant concentration of the Hanford Site contribution superimposed on the background and non-Hanford contributions.

E. Contaminant release from the groundwater model to the Columbia River will be simulated over the full extent of the area covered by the groundwater module. This will demonstrate that releases from the 100 Areas, 300 Area, and Central Plateau can be simulated as discharging to the Columbia River. It will also provide insight into the relative magnitude and timing of releases from each release area.

\section{Endpoints for Analysis}

A. The analysis will simulate the Columbia River from Vernita Bridge to the city of Richland. The analysis will also emulate 1) background and non-Hanford contributions of contaminant concentrations and 2) Hanford Site contributions superimposed over background and non-Hanford contributions of contaminant concentrations. These concentrations will provide the basis for estimating Hanford's impact to human health and supplemental ecosystem risk. 


\subsubsection{Risk and Impact Assessment}

The Composite Analysis requires a human health risk assessment. The supplemental ecological risk assessment module will be used to examine the impact to ecological species from Hanford Site releases to the environment. The conceptual models for risk assessment and impact predictions are discussed in PNNL-14027.

\section{Human Health Risk Assessment - Key Attributes}

A. The Human Health Risk Assessment Module will estimate cancer and non-cancer risk to humans from contaminants in the study region. The routes of exposure will vary based on the scenarios for the assessment. The scenarios are focused on the use of potentially contaminated water and exposure to potentially contaminated soil, sediment, and air.

B. The module will provide summary statistics of risk with regard to realizations at a given location and time combination.

C. Where the human health model relies on contamination to plant and animal species in the ecological model, a link has been created to provide the results of the ecological model as the basis for the human health simulation.

\section{Human Health Risk Assessment - Endpoints for Analysis}

A. The scenarios for the Human Health Risk Assessment Module are described further in the September 1999 Letter Report (Bechtel 1999). Other references for the scenarios include the Hanford Site Risk Assessment Methodology (DOE/RL-91-45) and Requirements for a Columbia River Comprehensive Impact Assessment Part II (DOE/RL-96-16). Scenarios describe the exposure from all pathways (ingestion, inhalation, and dermal) to environmental contaminants in the groundwater, surface water, and sediment, as well as through fish, meat, and produce that was also exposed to contaminants. The scenarios will include the following:

1. Locations at the Hanford Site will be assessed for the Residential Farmer and Native American user. The groundwater and air pathways will be the primary exposure routes. The model will include irrigation in the Residential Farmer scenario, which will add contamination from the groundwater to the irrigated soil. At 2035, the soil concentration will be zero and will increase over time due to the contribution of contaminants from the groundwater. This portion of the model is not dynamically linked to the Environmental Transport Modules and, therefore, the mass of the contaminants will not be conserved.

2. Along the edge of the Columbia River, the assessment will include the Ranger and the Native American user. The primary exposure route from contaminants is the river pathway, including surface water, pore water, and sediment.

3. The assessment will include scenarios that use the Columbia River, which include Recreational Users (casual and avid) and Residential Farmer. The Residential Farmer will be similar to the scenario on the Hanford Site, but the exposure will be from the river pathway rather than the groundwater pathway. Also, like the scenario on the Hanford Site, irrigation will result in soil contamination.

B. Two categories of impact, carcinogenic and systemic effects, will be estimated in the human health risk assessment that will demonstrate an adverse impact from a contaminant to humans. Impact will 
be assessed with the HUMAN computer code that was used in the Screening Assessment and Requirements for a Comprehensive Assessment Part I (DOE/RL-96-16). The metrics include the following:

1. Carcinogenic effects will be evaluated for the radionuclides and carcinogenic chemicals. The incremental lifetime cancer risk will be calculated using available slope factors, which assume additivity of toxic effects from all carcinogenic contaminants. In addition, the results of the human health impact assessment will be presented as an annual dose, which is specified under DOE Orders 5400.5 and 435.1.

2. Systemic effects will be evaluated for non-carcinogenic radionuclides (for example, the nephrotoxic effects of uranium) and chemicals. The hazard index will be calculated using available reference doses, which assume additivity of toxic effects from all non-carcinogenic contaminants.

C. Human health impact associated with the Columbia River will be based on both runs of the river module: background and non-Hanford contribution, and Hanford Site contribution superimposed over background and non-Hanford contribution.

\section{Supplemental Ecological Risk Assessment - Key Attributes}

A. The Ecological Risk Assessment Module will estimate risk from contaminants for a selected set of species and locations as a function of exposure and estimated body burdens. Species of interest will include riparian plants, riparian animals, aquatic plants, and aquatic animals.

B. The module will estimate changes in a limited set of community attributes as a function of exposure and body burden to the contaminants. This analysis will be performed after processing impact and will be based on typical outputs from the Ecological Chemical Exposure Model (ECEM).

C. The module will be able to provide summary statistics of risk with regard to all realizations at a given location and time combination.

\section{Supplemental Ecological Risk Assessment - Endpoints for Analysis}

A. The species of interest will be the Columbia River species as determined in the Screening Assessment and Requirements for a Comprehensive Assessment Part I, Section 4.1 (DOE/RL-96-16). These include the following:

1. Algae: periphyton and phytoplankton

2. Amphibians: Woodhouse's toad (tadpole, adult)

3. Aquatic invertebrates: clams/mussels/snails, crayfish, fresh water shrimp, mayfly, and water fleas

4. Birds: American coot, American kestrel, American white pelican, bald eagle, California quail, Canada goose/mallard, cliff swallow, common snipe, diving ducks, Forster's tern, great blue heron, and northern harrier

5. Emergent vegetation: tule

6. Fish: channel catfish, common carp, large scale sucker, mountain sucker, mountain whitefish, Pacific lamprey (juvenile), salmon (eggs, larvae, adults), small mouth bass, rainbow trout (eggs, larvae, adults), and white sturgeon

7. Fungi: as a taxonomic group

8. Macrophytes: Columbia yellowcress and water milfoil

9. Mammals: beaver, coyote, mule deer, muskrat, raccoon, weasel, and western harvest mouse 
10. Reptiles: side-blotched lizard and western garter snake

11. Terrestrial vegetation: black cottonwood, dense sedge, ferns, reed canary grass, rushes, and white mulberry

B. Two categories of impact will be estimated in the ecological risk assessment that will demonstrate an adverse impact from a contaminant to an ecological receptor. The species of interest will be the Columbia River species as determined in the Screening Assessment and Requirements for a Comprehensive Assessment Part I (DOE/RL-96-16). The metrics include the following:

1. Impact on individual species will be measured by modeling the exposure of a species to a contaminant, and then comparing the dose or body burden of the species to a toxicity parameter (for example, the lowest observed adverse effect level). The results will be location and time specific, and the measure will be no effect, chronic effect, or potential acute effect (using a toxicity benchmark).

2. Impact on ecosystems will be estimated as a post-processing function by analyzing food web impact and adverse changes to the ecosystem structure and function. This analysis will be performed after processing impact and will be based on typical output from ECEM. The ecosystem impact will be described through an analysis of higher level effects on the structure and function of the Columbia River ecosystem. This analysis will be based on the guild structure of the Columbia River species and on a food web of this ecosystem, which will consist of the food web in the Columbia River comprehensive impact assessment version of ECEM (DOE/RL-96-16). The guild structure combines Columbia River species into groups on the basis of shared aspects of lifestyle, habitat affinities, and trophic relationships. The food web identifies the consumption patterns of the primary species within this ecosystem.

The analysis will use the impact on species (as mentioned above) and be converted to relative losses of numbers (or biomass) through simple population-effect models. Effects on guild members will be tallied to provide an index of relative impact on species guilds within the Columbia River system. Effects on biomass flow within the system will be estimated using a linear algebra model. In this model, the relative consumption fraction matrix of the food web is pre-multiplied by abundance (kilogram/meter ${ }^{2}$ ) and an abundance reduction due to exposure (unitless), and post-multiplied by predator ingestion rate (kilogram prey/kilogram predator/day) and time of simulation (days) to obtain mass flow from each prey item to all predators (kilogram/meter ${ }^{2}$ ). Effects from different exposures will be apparent as changes in mass flow under those differing conditions over time.

C. Ecological impact associated with the Columbia River will be based on both runs of the river module: background and non-Hanford contribution, and Hanford Site contribution superimposed over background and non-Hanford contribution.

\subsection{System Assessment Capability Tool}

SAC is a set of models and data that have been assembled since the previous 1998 Composite Analysis was performed to allow the collective impact of all the waste that will remain at the Hanford Site to be estimated. Computer codes that have been well tested at the Hanford Site have been used when possible and new software has been written when necessary to simulate the features and processes that affect the release of contaminants into the environment, transport of contaminants through the environment, and the impact those contaminants have on living systems, cultures and the local economy. The components have been organized to simulate the transport and fate of contaminants from their presence in Hanford waste sites, through their release into the vadose zone, to their movement in the groundwater, and into the Columbia River. Components of SAC such as the groundwater model, the ecological impact component, and the human health component were originally developed and tested for previous Hanford assessments. 
The SAC computational tool include the following elements:

- Inventory Module - develops an inventory of specific waste disposal and storage locations for the period 1944 to Hanford Site closure based on disposal records, process knowledge, and the results of tank and field samples. The year 2035 is used as the Hanford Site closure date for the 2004 Composite Analysis because it has been identified as the time of site closure for major facilities (such as, tanks, solid waste burial grounds, chemical separations plants). Future runs will use the closure date predicted at the time of the run. This module also identifies the material scheduled for disposal in offsite repositories, including high-level waste, transuranic waste, and spent fuel.

- Release Module - simulates the annual release of contaminants to the vadose zone from the variety of waste types in the modeled waste sites. This module also simulates future remediation actions that move waste to ERDF.

- Air Transport Module - simulates the transport of contaminants through the air from release points to points of deposition.

- Vadose Zone Transport Module - simulates fluid flow and contaminant transport in the vadose zone, which is the unsaturated sediment between the land surface and the unconfined aquifer.

- Groundwater Transport Module - simulates the fluid flow and contaminant transport in the unconfined aquifer that underlies the Hanford Site using the transient inverse calibrated threedimensional site-wide groundwater model.

- Soil Module - simulates the buildup of contaminants in the plant root-zone soil layer due to air deposition and irrigation. Solutions are available for the cases of no irrigation, irrigation with groundwater, and irrigation with river water.

- River Module - simulates river flow and contaminant/sediment transport in the Hanford Reach from Vernita Bridge downstream to McNary Dam. This module simulates background concentrations and background plus the Hanford Site concentrations to enable an assessment of the Hanford Site incremental impact to the Columbia River and its ecosystem.

- Riparian Zone Module - uses river and groundwater information to simulate the concentration of contaminants in seep or spring water and in the wet soil near the edge of the river.

- Risk/Impact Modules - perform risk/impact analysis in four topical areas: human health, ecological health, economic impact, and cultural impact with the latter two being new impact metrics for Hanford assessments. The human health risk module will be applied in the 2004 Composite Analysis. Other modules of risk/impact will be applied to inform the public and regulators regarding issues related to the Composite Analysis (for example, chemical hazards and ecological impact).

Each module was assembled so that it could be tested and evaluated independently of the other modules. The inventory, release, environmental pathways, and risk/impact were then linked to test the overall performance of the system. 
The conceptual illustration of SAC (Figure 3.1) portrays a linear flow of information. In general, inventory feeds to release to the atmospheric, vadose zone, groundwater, and Columbia River pathways. At times, release occurs directly to the groundwater through reverse wells and to the Columbia River from the single-pass reactors. During chemical separation plant operation, release occurred to the atmosphere. The atmosphere, groundwater, Columbia River and riparian zone technical elements provide media-specific concentration estimates used in the risk and impact assessment.

\section{System Assessment Capability Conceptual Model}

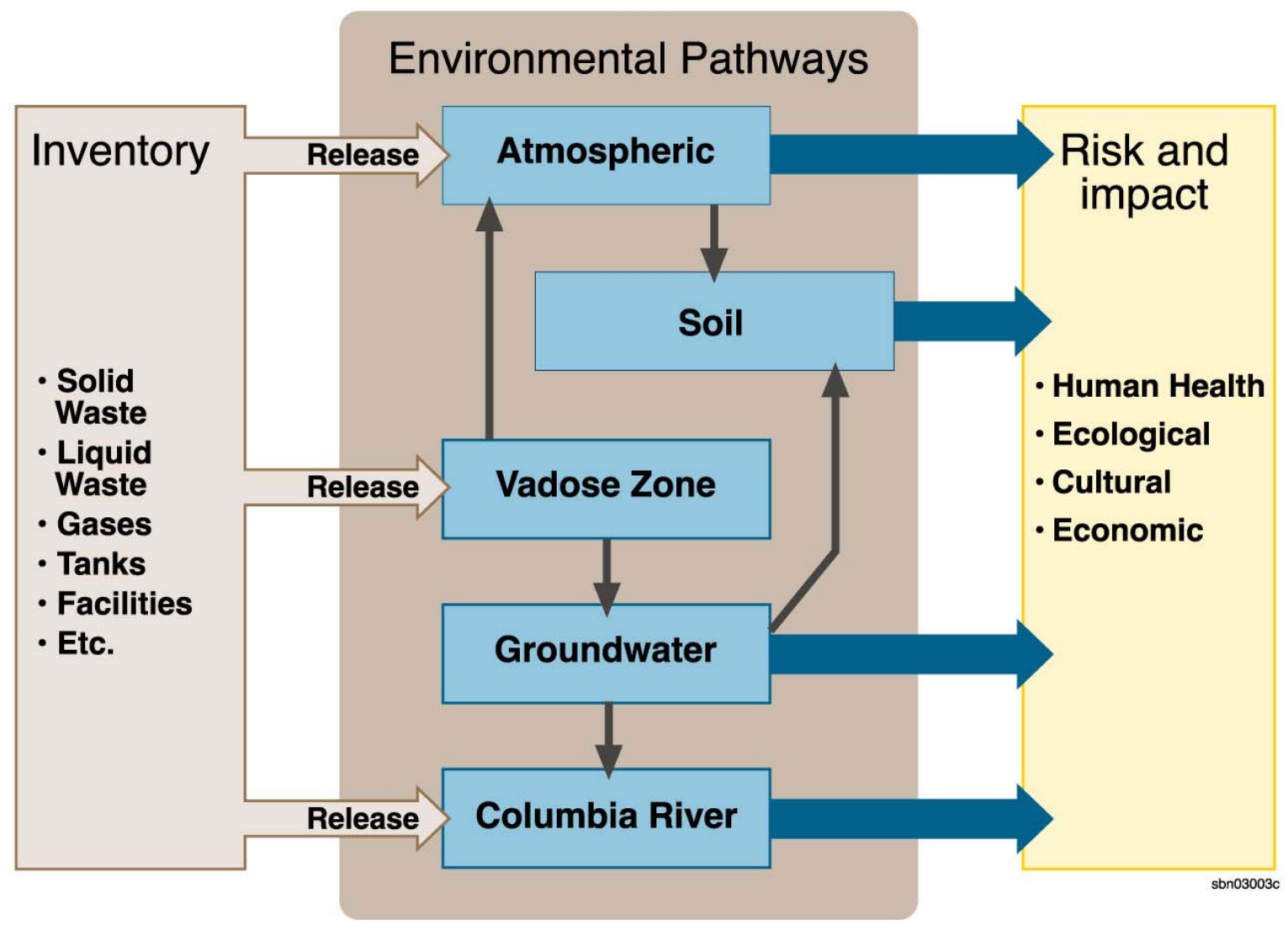

Figure 3.1. Conceptual Model of the System Assessment Capability

One of the challenges associated with performing an assessment is appropriately presenting how well the results predict what might actually occur. This is because the attributes of the site that effect transport of contaminants, the impact of contaminants on living systems, and the future conditions used in the assessment, as well as many other factors upon which the predictions depend, are not completely understood. SAC was developed to allow the performance of a probabilistic risk assessment so an indication of the effect of parameter uncertainty on results could be examined. In general, other sources of uncertainty, such as conceptual model uncertainty, will not be handled within the calculations but will be discussed in the interpretation of the results of this analysis.

For the 2004 Composite Analysis, SAC will be modified to enable the import of results from detailed assessments of individual waste sites by other programs. Such results come from the immobilized low 
activity waste site performance assessment. Information on 1) release to vadose zone or 2) release to water table will be imported into the SAC deterministic analysis. The 2004 Composite Analysis will treat best estimate simulations by other programs as "median" simulations and incorporate them into an overall "median-input" deterministic simulation. Simulations completed and reported on tank farm past leaks, retrieval losses, and residuals will be used to condition the SAC tool parameters such that the 2004 Composite Analyses of these events approximate published results.

To perform a stochastic analysis, best-estimate data (geologic profile, hydraulic properties, geochemical properties, recharge sequence, etc.) used by other programs to perform assessments will be interpreted as "median" values for distributions where the data range is defined by the Hanford wide data set previously compiled for SAC. A simplified model (such as, release and one-dimensional vadose zone or release and two-dimensional vadose zone) will be calibrated or conditioned to reproduce key aspects of the median simulation provided by the detailed assessment. This simplified but calibrated model will be used to generate the stochastic realizations. Where available, comparison will be made between the range of SAC stochastic responses and the range of deterministic sensitivity cases provided by the program.

Significant differences may exist between the SAC representation of uncertainty and the representation of sensitivity presented in other assessments. This is especially true when the site specific assessment is using sensitivity analyses to explore alternate conceptual models of waste form release (for example, tank residuals modeled with a solubility model, diffusion model, advection-desorption model, linear releasetime-model) or barrier performance (for example, alternate surface barriers and engineered containment systems surrounding a glass waste form).

Background information for the development of the initial SAC is presented in Groundwater/Vadose Zone Integration Project: Preliminary System Assessment Capability Concepts for Architecture, Platform and Data Management (Bechtel 1999), which can be found at http://www.hanford.gov/cp/gpp/modeling/sacarchive.cfm. This document includes a description of alternate architectures for SAC as well as conceptual models for each technical element of the capability. Design of the initial SAC tool is summarized in BHI-01365. Results of an initial assessment performed with the SAC are provided in PNNL-14027, and a description of the software is provided in PNNL-13932, Volumes 1 and 2.

\subsection{Incorporation of the Data and Results from Other Studies}

The 2004 Composite Analysis is a companion site-wide assessment to waste-specific and site-specific assessments. It is required for continued disposal authorization for active and planned disposals of ILAW, spent vitrification plant melter components, and low-level waste in the 200 East and 200 West Solid Waste Burial Grounds or the newly designed Integrated Disposal Facility to be located in 200 East Area, and CERCLA waste in ERDF.

Every effort is being made to represent these specific sites in the 2004 Composite Analysis in the same way they are represented in site-specific analyses. Some differences may occur, for example when a sitespecific analysis is performed as a bounding analysis and the Composite Analysis is run to provide our best estimate of future conditions. In general, however, both parties strive for consistency in the assessments. 
Input data for the 2004 Composite Analysis must be available by June 1, 2004 to complete the assessment and submit the documentation to DOE by July 31,2005. A number of site-specific assessments will be performed during the period when the 2004 Composite Analysis is being performed. Data generated in the process of running these site-specific assessments may not be available on June 1, 2004 and so not included in the 2004 Composite Analysis. The impact these new data would have on the 2004 Composite Analysis results will be evaluated in the annual summaries performed in the future. The following assessments are planned for the future:

- S/SX Tank Farm risk assessment (spring 2004)

- Hanford Solid Waste Environmental Impact Statement (winter 2004)

- Tank Closure Environmental Impact Statement (spring 2005)

- T/TX/TY Tank Farm field investigation report (winter 2005)

- 2005 IDF Performance Assessment (summer 2005)

- Remedial Field Investigation rollup of A, AX, C, and U Tank Farms (Resource Conservation and Recovery Act-RCRA--Primary Document) (fall 2006)

- Remedial Field Investigation /Corrective Measures Study rollup of A, AX, C, and U Tank Farms (RCRA Primary Document) (spring 2007).

The S/SX Tank Farm field investigation report (RPP-7884) and the B/BX/BY Tank Farm field investigation report (RPP-10098) have been published. Annual summaries for the ILAW and Solid Waste Burial Ground performance assessments were published in 2002 (Mann 2002) and VanVliet $2002^{2}$ will be updated and re-issued in 2003.

The results of these assessments will be compared with the results of the 2004 Composite Analysis and considered in future annual summaries as appropriate.

\footnotetext{
${ }^{2}$ Letter No. FH-0204558 from JA Van Vliet, (VP Waste Management Project), to MH Schlender,(Deputy Mgr, US Dept Energy), Performance Assessment Review Report, 2001-2002 Annual Review of the 200 West and 200 East Area Performance Assessments. Fluor Hanford, Inc., Richland, Washington, dated September 30, 2002.
} 


\subsection{Documentation of Analysis and Results}

DOE's Format and Content Guide for U.S. Department of Energy Low-Level Waste Disposal Facility Performance Assessments and Composite Analyses (DOE 1999) recommends the format and content for a composite analysis to fulfill the requirements of DOE Order 435.1. The format and content guide gives a structure for preparing composite analyses to enhance consistency and facilitate technically sound reviews and decision making processes.

The sidebar shows the proposed content for the Hanford Site 2004 Composite Analysis. It basically follows the DOE (1999) guide. It makes adjustments to fit the situation at the Hanford Site that will "allow an independent reviewer to conclude that the site-specific analysis of performance is complete, logical, technically correct, rigorous and defensible" (DOE1999, p. B-1).

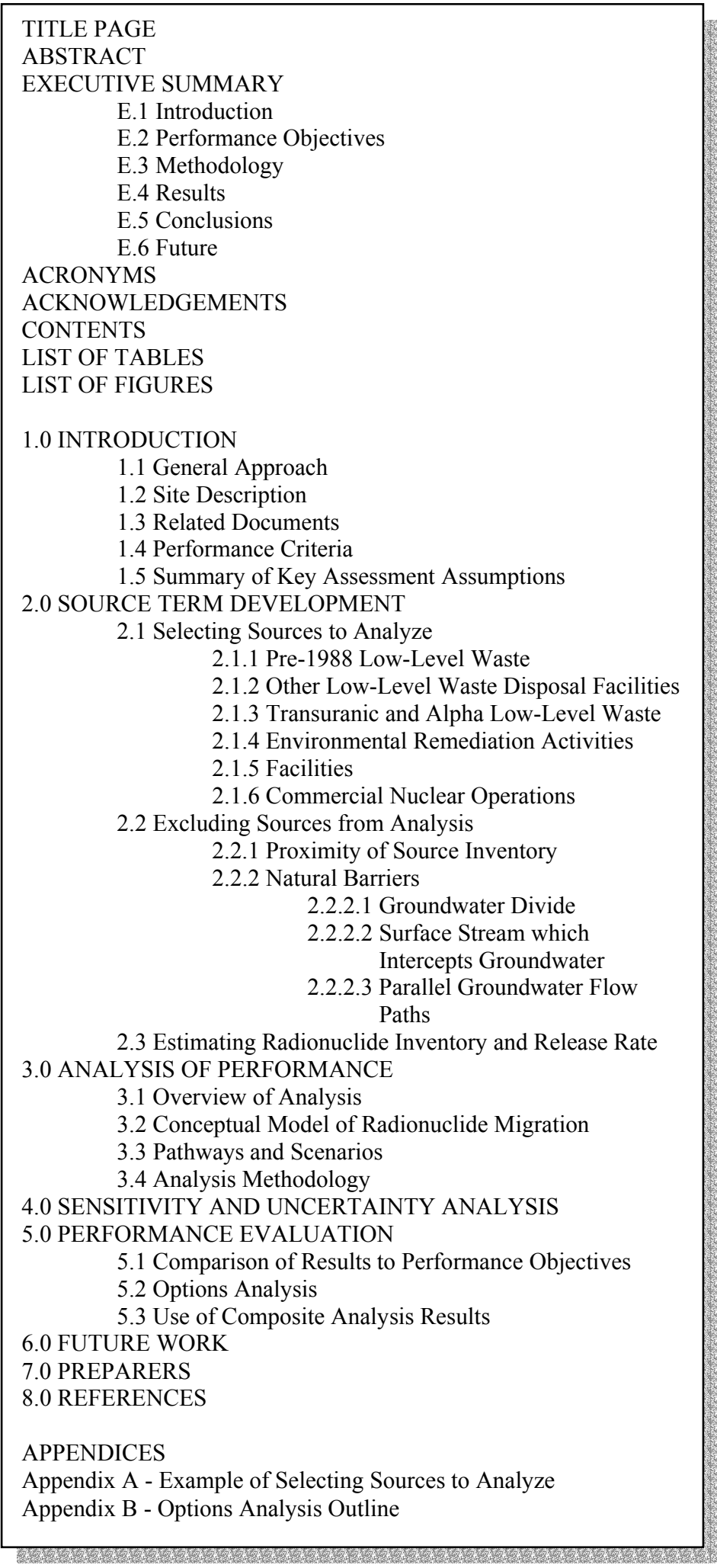




\subsection{References}

58 FR 48509. September 16, 1993. ““'Department of Energy, Record of Decision: Decommissioning of Eight Surplus Production Reactors at the Hanford Site, Richland, WA." Federal Register.

64 FR 61615. November 12, 1999. U.S. Department of Energy, "Record of Decision: Hanford Comprehensive Land-Use Plan Environmental Impact Statement (HCP EIS).” Federal Register.

65 FR 37253. June 13, 2000. Presidential Proclamation 7319, "Establishment of the Hanford Reach National Monument." Federal Register.

Bechtel. 1999. Groundwater/Vadose Zone Integration Project: Preliminary System Assessment Capability Concepts for Architecture, Platform and Data Management. Bechtel Hanford Inc., Richland, Washington. Available on the Internet at http://www.hanford.gov/cp/gpp/modeling/sacarchive.cfm.

BHI-01365. 2000. Groundwater/Vadose Zone Integration Project, System Assessment Capability (Revision 0), Assessment Description, Requirements, Software Design, and Test Plan. CT Kincaid, PW Eslinger, WE Nichols, AL Bunn, RW Bryce, TB Miley, MC Richmond, SF Snyder, and RL Aaberg, Bechtel Hanford Inc., Richland, Washington.

BHI-01496 Rev 0 (also LA-UR-00-4050). 2001. Hanford Soil Inventory Model. BC Simpson, RA Corbin, and SF Agnew, Bechtel Hanford Inc., Richland, Washington.

BHI-01673 Rev 0. 2003. 100-B/C Area Ecological Risk Assessment Data Quality Objectives. PG Doctor, KA Gano, RG Bauer, JK Linville, and TM Poston, Bechtel Hanford Inc., Richland, Washington.

CERCLA - Comprehensive Environmental Response, Compensation, and Liability Act. 1980. Public Law 96-150, as amended, 94 Stat. 2767, 42 USC 9601 et seq.

DOE . 1999. Format and Content Guide for U.S. Department of Energy Low-Level Waste Disposal Facility Performance Assessments and Composite Analyses. U.S. Department of Energy Headquarters, Washington, D.C. http://www.em.doe.gov/lfrg/format_guide.pdf

DOE/EIS-0119D. 1989. Decommissioning of Eight Surplus Production Reactors at the Hanford Site, Richland, Washington. U.S. Department of Energy, Washington, D.C.

DOE/EIS-0119F. 1992. Decommissioning of Eight Surplus Production Reactors at the Hanford Site, Richland, Washington, Addendum. U.S. Department of Energy, Washington, D.C.

DOE/EIS-0222-F. 1999. Final Hanford Comprehensive Land-Use Plan Environmental Impact Statement. U.S. Department of Energy, Richland, Washington.

DOE/EIS-0286D2. 2003. Revised Draft Hanford Site Solid (Radioactive and Hazardous) Waste Program Environmental Impact Statement, Richland, Washington. U.S. Department of Energy, Richland, Washington. 
DOE/EM-0319. 1997. Linking Legacies: Connecting the Cold War Nuclear Weapons Production Processes to Their Environmental Consequences. U.S. Department of Energy, Washington, D.C.

DOE G435.1-1. 1999. Implementation Guide for Use with DOE M 435.1-1. U.S. Department of Energy Headquarters, Washington, D.C.

DOE M435.1-1. 1999. Radioactive Waste Management Manual. U.S. Department of Energy Headquarters, Washington, D.C. Available on the Internet at http://www.directives.doe.gov/pdfs/doe/doetext/neword/435/m4351-1c1.html

DOE Order 435.1. 1999. Radioactive Waste Management. U.S. Department of Energy Headquarters, Washington, D.C. Available on the Internet at http://www.hanford.gov/wastemgt/doe/psg/pdf/doeo435.1.pdf.

DOE Order 5400.5, Change 2. 1993. Radiation Protection of the Public and the Environment. U.S. Department of Energy Headquarters, Washington, D.C.

DOE/ORP-2000-19, Rev. 2. 2002. Annual Summary of ILAW Performance Assessment for 2002. FM Mann, CH2M HILL Hanford Group, Inc., Richland, Washington.

DOE/ORP-2000-24 Rev 0, (formerly DOE/RL-97-69). 2001. Hanford Immobilized Low-Activity Waste Performance Assessment: 2001 Version. FM Mann, KC Burgard, WR Root, RJ Puigh, SH Finfrock, R Khaleel, DH Bacon, EJ Freeman, BP McGrail, SK Wurstner, PE LaMont, U.S. Department of Energy, Office of River Protection, Richland, Washington.

DOE/RL-91-45 Rev 3. 1995. Hanford Site Risk Assessment Methodology. U.S. Department of Energy Richland Operations Office, Richland, Washington.

DOE/RL-93-99 Rev 1. 1994. Remedial Investigation and Feasibility Study Report for the Environmental Restoration Disposal Facility. U.S. Department of Energy Richland Operations Office, Richland, Washington.

DOE/RL-96-16 Rev 1 (Final). 1998. Requirements for a Columbia River Comprehensive Impact Assessment Part II. U.S. Department of Energy Richland Operations Office, Richland, Washington.

DOE/RL-96-92. 1996. Hanford Strategic Plan. U.S. Department of Energy Richland Operations Office, Richland, Washington.

DOE/RL-2000-29 Rev 2. 2003. Maintenance Plan for the Composite Analysis of the Hanford Site, Southeast Washington. Prepared for the U.S. Department of Energy Richland Operations Office by the Pacific Northwest National Laboratory, Richland, Washington.

DOE/RL-2003-26. 2003. Annual Status Report: Composite Analysis of Low-Level Waste Disposal in the Central Plateau at the Hanford Site. RD Hildebrand, MP Bergeron, and RW Bryce, U.S. Department of Energy Richland Operations Office, Richland, Washington. 
EPA/600/R-96/055. 2000. Guidance for the Data Quality Objective Process, EPA QA/G-4. U.S. Environmental Protection Agency, Washington, D.C. Available on the Internet at http://www.hanford.gov/dqo/keyelements.html.

Gephart, RE, and RE Lundgren. 1998. Hanford Tank Cleanup: A Guide to Understanding the Technical Issues. Fourth edition, Battelle Press, Columbus, Ohio.

HNF-SD-WM-SP-012 Rev 4. 2002. Tank Farm Contractor Operation and Utilization Plan. RA Kirkbride, GK Allen, BA Higley, TM Hohl, SL Lambert, RM Orme, DE Place, JA Seidl, RS Wittman, JH Baldwin, JN Strode, JA Reddick, and LM Swanson, CH2M HILL Hanford Inc., Richland, Washington.

LA-UR-96-3860. 1997. Hanford Tank Chemical and Radionuclide Inventories: HDW Model Rev. 4. SF Agnew, J Boyer, RA Corbin, TB Duran, JR Fitzpatrick, KA Jurgensen, TP Ortiz, and BL Young, Los Alamos National Laboratory, Los Alamos, New Mexico.

NUREG-1741. 2001. RASCAL 3.0: Description of Models and Methods. AL Sjoreen, JV Ramsdell Jr., TJ McKenna, SA McGuire, C Fosmire, and GF Athey, U.S. Nuclear Regulatory Commission, Washington, D.C.

P.L. 94-171. 2001. Census 2000 Redistricting Data. U.S. Census Bureau, Washington D.C. Available on the Internet at http:/www.ofm.wa.gov/census2000/index.htm.

PNL-6415, Rev 14. 2002. Hanford Site National Environmental Policy Act (NEPA) Characterization. DA Neitzel (editor), AL Bunn, JP Duncan, TO Eschbach, RA Fowler, BG Fritz, SM Goodwin, DW Harvey, PL Hendrickson, DJ Hoitink, DG Horton, GV Last, TM Poston, EL Prendergast, AC Rohay, MJ Scott, and PD Thorne, Pacific Northwest National Laboratory, Richland, Washington.

PNL-8332. 1992. Status Report on the Development of a Three-Dimensional Conceptual Model for the Hanford Site Unconfined Aquifer System. PD Thorne and MA Chamness, Pacific Northwest Laboratory, Richland, Washington.

PNL-8971. 1993. Three-Dimensional Conceptual Model for the Hanford Site Unconfined Aquifer System, FY 93 Status Report. PD Thorne, MA Chamness, FA Spane Jr., VR Vermeul, and WD Webber, Pacific Northwest Laboratory, Richland, Washington.

PNL-10195. 1994. Three-Dimensional Conceptual Model for the Hanford Site Unconfined Aquifer System: FY 1994 Status Report. PD Thorne, MA Chamness, VR Vermeul, QC Macdonald, and SE Schubert, Pacific Northwest Laboratory, Richland, Washington.

PNL-10285. 1995. Estimated Recharge Rates at the Hanford Site. MJ Fayer and TB Walters, Pacific Northwest Laboratory, Richland, Washington.

PNL-10886. 1995. Development of a Three-Dimensional Groundwater Model of the Hanford Site Unconfined Aquifer System: FY 1995 Status Report. SK Wurstner, PD Thorne, MA Chamness, MD Freshley, and MD Williams, Pacific Northwest Laboratory, Richland, Washington. 
PNNL-11472. 1997. Hanford Site Environmental Report for Calendar Year 1996. RL Dirkes and RW Hanf (eds.), Pacific Northwest National Laboratory, Richland, Washington.

PNNL-11800. 1998. Composite Analysis for Low-Level Waste Disposal in the 200-Area Plateau of the Hanford Site. CT Kincaid, MP Bergeron, CR Cole, MD Freshley, NL Hassig, VG Johnson, DI Kaplan, RJ Serne, GP Streile, DL Strenge, PD Thorne, LW Vail, GA Whyatt, and SK Wurstner, Pacific Northwest National Laboratory, Richland, Washington.

PNNL-11801. 1997. Three-Dimensional Analysis of Future Groundwater Flow Conditions and Contaminant Plume Transport in the Hanford Site Unconfined Aquifer System: FY 1996 and 1997 Status Report. CR Cole, SK Wurstner, MP Bergeron, MD Williams, and PD Thorne, Pacific Northwest National Laboratory, Richland, Washington.

PNNL-13447. 2001. Transient Inverse Calibration of the Site-Wide Groundwater Flow Model to the Hydraulic Impacts of the Unconfined Aquifer System from Hanford Operations, Southeastern Washington-1943-1996. CR Cole, MP Bergeron, SK Wurstner, PD Thorne, S Orr, and M McKinley, Pacific Northwest National Laboratory, Richland, Washington.

PNNL-13623. 2001. Transient Inverse Calibration of the Site-Wide Groundwater Flow Model to Hanford Operational Impacts from 1943 to 1996-Alternative Conceptual Model Considering Interaction with Uppermost Basalt Confined Aquifer. VR Vermeul, CR Cole, MP Bergeron, SK Wurstner, and PD Thorne, Pacific Northwest National Laboratory, Richland, Washington.

PNNL-13641. 2001. Uncertainty Analysis Framework for the Site-Wide Groundwater Flow and Transport Modeling at the Hanford Site, Southeast Washington. CR Cole, PD Thorne, MP Bergeron, SK Wurstner, C Murray, and P. Rogers, Pacific Northwest National Laboratory, Richland, Washington.

PNNL-13910. 2002. Hanford Site Environmental Report for Calendar Year 2001. TM Poston, RW Hanf, RL Dirkes, and LF Morasch (eds.), Pacific Northwest National Laboratory, Richland, Washington. Available on the Internet at http://hanford-site.pnl.gov/envreport/2001/.

PNNL-13932 Vol 1. 2002. User Instructions for the Systems Assessment Capability, Rev. 0, Computer Codes; Volume 1: Inventory, Release, and Transport Modules. PW Eslinger, DW Engel, LH Gerhardstein, CA LoPresti, WE Nichols, and DL Strenge, Pacific Northwest National Laboratory, Richland, Washington.

PNNL-13932 Vol 2. 2002. User Instructions for the Systems Assessment Capability, Rev. 0, Computer Codes; Volume 2: Impact Modules. PW Eslinger, C Arimescu, BA Kanyid, and TB Miley, Pacific Northwest National Laboratory, Richland, Washington.

PNNL-14027. 2002. An Initial Assessment of Hanford Impact Performed with the System Assessment Capability. RW Bryce, CT Kincaid, PW Eslinger, and LF Morasch (editors), Pacific Northwest National Laboratory, Richland, Washington.

PNNL-14187. 2003. Hanford Groundwater Monitoring for Fiscal Year 2002. MJ Hartman, LF Morasch, and WD Webber (eds.), Pacific Northwest National Laboratory, Richland, Washington. 
PNWD-2224 HEDR. 1994. Regional Atmospheric Transport Code for Hanford Emission Tracking (RATCHET). JV Ramsdell Jr, CA Simonen, and KW Burk, Battelle, Pacific Northwest Laboratories, Richland, Washington.

RPP-7884 Rev 0. 2002. Field Investigation Report for Waste Management Area S-SX; Volume 1, Main Text and Appendices A - C; Volume 2, Appendices D - I. AJ Knepp, CH2M HILL Hanford Group Inc., Richland, Washington.

RPP-10098 Rev 0. 2002. Field Investigation Report for Waste Management Area B-BX-BY; Volume 1, Main Text and Appendices A - C; Volume 2, Appendices D - I. AJ Knepp, Jacobs Engineering Group Inc., Richland, Washington.

van Genuchten, M. 1980. "A Closed-Form Equation for Predicting the Hydraulic Conductivity of Unsaturated Soils.” Soil Sci. Am. J. 44:892-898.

WHC-SD-WM-TI-730 Rev 0. 1996. Performance Assessment for the Disposal of Low-Level Waste in the 200-East Area Burial Grounds. MI Wood, R Khaleel, PD Rittmann, SH Finfrock, TH DeLorenzo, and DY Garbrick, Westinghouse Hanford Company, Richland, Washington. 
Appendix

2004 Composite Analysis - Modified Data Quality Objectives 


\section{Appendix 2004 Composite Analysis - Modified Data Quality Objectives}

A composite analysis is required by U.S. Department of Energy (DOE) Order 435.1 to ensure public safety through the management of active and planned low-level radioactive waste disposal facilities associated with the Hanford Site. The data quality objective (DQO) process described in Guidance for the Data Quality Objective Process (EPA/600/R-96/055) was used to define the technical scope for the 2004 Composite Analysis. The standard 7-step DQO process (EPA/600/R-96/055) was developed for data sampling programs, with the 7 steps being:

- Step 1: State the Problem

- Step 2: Identify Decisions

- Step 3: Identify Inputs for Analysis

- Step 4: Specify Boundaries of Analysis

- Step 5: Define Decision Rules

- Step 6: Specify Error Tolerances on Decision Rules

- Step 7: Optimize Analysis Design.

The first 5 steps of the DQO process work well for developing the scope of the 2004 Composite Analysis. Steps 6 and 7 are very important when developing a sampling plan but are not applicable when planning a Composite Analysis.

Step 5 of the DQO involves the formulation of "decision rules" while Step 2 identifies decisions. DOE Order 435.1 prescribes both the decision (Step 2) and identifies the metrics to be used in the decision rule (Step 5). For this document, these two steps will be combined and presented under Step 2.

Step 6 deals with the "specific limits of the decision error" and is geared towards sampling error issues (Type 1 and Type 2 errors) associated with characterization and sampling data plans. The 2004 Composite Analysis will not include sampling plans specifically, but it will include characterization data from other studies and may influence their sampling plans.

Step 7 entails the "optimization of the design for obtaining data." Again, this step does not fit the primary purpose of the Composite Analysis, which is an assessment and not a sampling effort.

Contributors to the DQO effort were selected to provide expertise on contaminants currently in the environment or predicted to be released to the environment over the period included in the Composite Analysis. Table A.1 identifies the contributors, their organization, and technical area of expertise. Doug Hildebrand and John Morse are responsible for DOE oversight for the 2004 Composite Analysis and interaction between relevant DOE programs. In addition the results of past assessments and the plans for the Composite Analysis were discussed with staff from the Washington State Department of Ecology, U.S. Environmental Protection Agency, the Nez Perce Tribe, the Confederated Tribes of the Umatilla Indian Reservation and the Yakama Nation. 
Table A.1. Contributors to the Data Quality Objective effort

\begin{tabular}{|l|l|}
\hline \multicolumn{1}{|c|}{ Name } & \multicolumn{1}{c|}{ Role and Responsibility } \\
\hline U.S. Department of Energy Richland Operations Office \\
\hline Doug Hildebrand & $\begin{array}{l}\text { Oversight of Composite Analysis preparation and groundwater model } \\
\text { development }\end{array}$ \\
\hline John Morse & Oversight of Groundwater Protection Program \\
\hline Fluor Hanford Inc. & Groundwater remediation and pump \& treat \\
\hline Jane Borghese & Waste site remediation and pump \& treat \\
\hline Tom Fogwell & Waste site remediation \\
\hline Bruce Ford & Hanford Site groundwater model and Composite Analysis \\
\hline Pacific Northwest National Laboratory \\
\hline Marcel Bergeron & Site-wide assessments and System Assessment Capability (SAC) analyses \\
\hline Robert Bryce & Site-wide assessments, analyses, Composite Analysis \\
\hline Charley Kincaid & DOE Office of River Protection tank retrieval and closure risk assessment \\
\hline CH2M HILL Hanford Group Inc. \\
\hline Tony Knepp & DOE Office of River Protection tank retrieval and closure risk assessment \\
\hline Fred Mann
\end{tabular}

\section{Step 1: State the Problem}

The 2004 Composite Analysis will be a site-wide evaluation of the potential long-term radiological impact on the health of a hypothetical future member of the public. The human health impact will be evaluated from combined radionuclide releases to groundwater, surface water, and air from multiple sources during the 1000-year period following closure of the Hanford Site. In addition to the analysis required under DOE Order 435.1, DOE-RL will perform a supplemental analysis to examine the ecological impact from radiological contaminants and conduct an analysis on a select number of chemicals. The problem statement for the human health impact is:

Predict the maximum annual dose to a hypothetical future member of the public resulting from combined radionuclide releases to groundwater, surface water, and air from multiple sources during the 1000-year regulatory period following closure of the Hanford Site in 2035.

The following problem statement was also identified due to the presence of hazardous chemicals in Hanford waste:

Predict the maximum annual impact (carcinogenic and non-carcinogenic) to a hypothetical future member of the public resulting from combined chemical releases to groundwater, surface water, and air from multiple sources during the 1000-year period following closure of the Hanford Site in 2035.

Although the Composite Analysis regulatory assessment period is 1000 years, the 2004 Composite Analysis will extend the calculations up to 10,000 years post closure to evaluate impact beyond the 
1000-year period of analysis if the maximum is not realized during the first 1000 years after site closure. Results of the regulatory period of assessment will be compared to site-wide performance objectives. The extended calculation may increase the understanding of the disposal facility performance and the models used but will not be used for evaluating compliance against site-wide disposal performance objectives after the regulatory period of 1000 years post closure.

\section{Key Assumptions}

Key assumptions associated with the 2004 Composite Analysis include:

- Domain of the analysis will be the Hanford Site from Rattlesnake Mountain to the Columbia River, and the Columbia River from Vernita Bridge to the city of Richland

- The Waste Information Data System (WIDS) site list as of January 2003 was used to define an initial list of the radioactive waste disposal sites of interest for this study - those for which sufficient information is available for analysis. Information from other programs at the Hanford Site will be incorporated into the analysis as made available.

- The 2004 Composite Analysis is a snapshot of a moment in time within an evolving set of waste site assessments. Each waste site assessment has its own schedule and objectives that may not correspond to those of the 2004 Composite Analysis. Because of the speed with which decisions are made and changed, each analysis may become obsolete or out of step with allied analyses before it is completed and published. The 2004 Composite Analysis will freeze all data used for simulations on June 1, 2004.

- The stochastic component of the 2004 Composite Analysis will be limited to 100 or fewer realizations, which will limit the uncertainty analysis to central tendency type studies. This means the uncertainty analysis cannot be used for extreme values, such as $90^{\text {th }}$ or $95^{\text {th }}$ percent confidence interval.

- The current regional and local climate remains unchanged for the period of analysis.

- The analysis of background and non-Hanford contributions to contamination and risk will consider only the Columbia River.

\section{Contaminants of Concern}

The list of contaminants being considered in the 2004 Composite was developed using a variety of perspectives and screening criteria. The process was initiated in a workshop held on February 25, 2003 attended by staff from Hanford programs with experience in Performance Assessment modeling and environmental monitoring. One product of the workshop was the identification of a preliminary list of contaminants of concern based on the collective experience of the attendees. This preliminary list of contaminants of concern along with the primary basis for including it on the list is provided in Table A.2

A significant suggestion for further identification of contaminants of concern made during the workshop was to evaluate the extensive groundwater monitoring data collected at the Hanford Site to help focus the 
Table A.2. Contaminants of Potential Concern Selected at February 25, 2003 Workshop $^{\text {a }}$

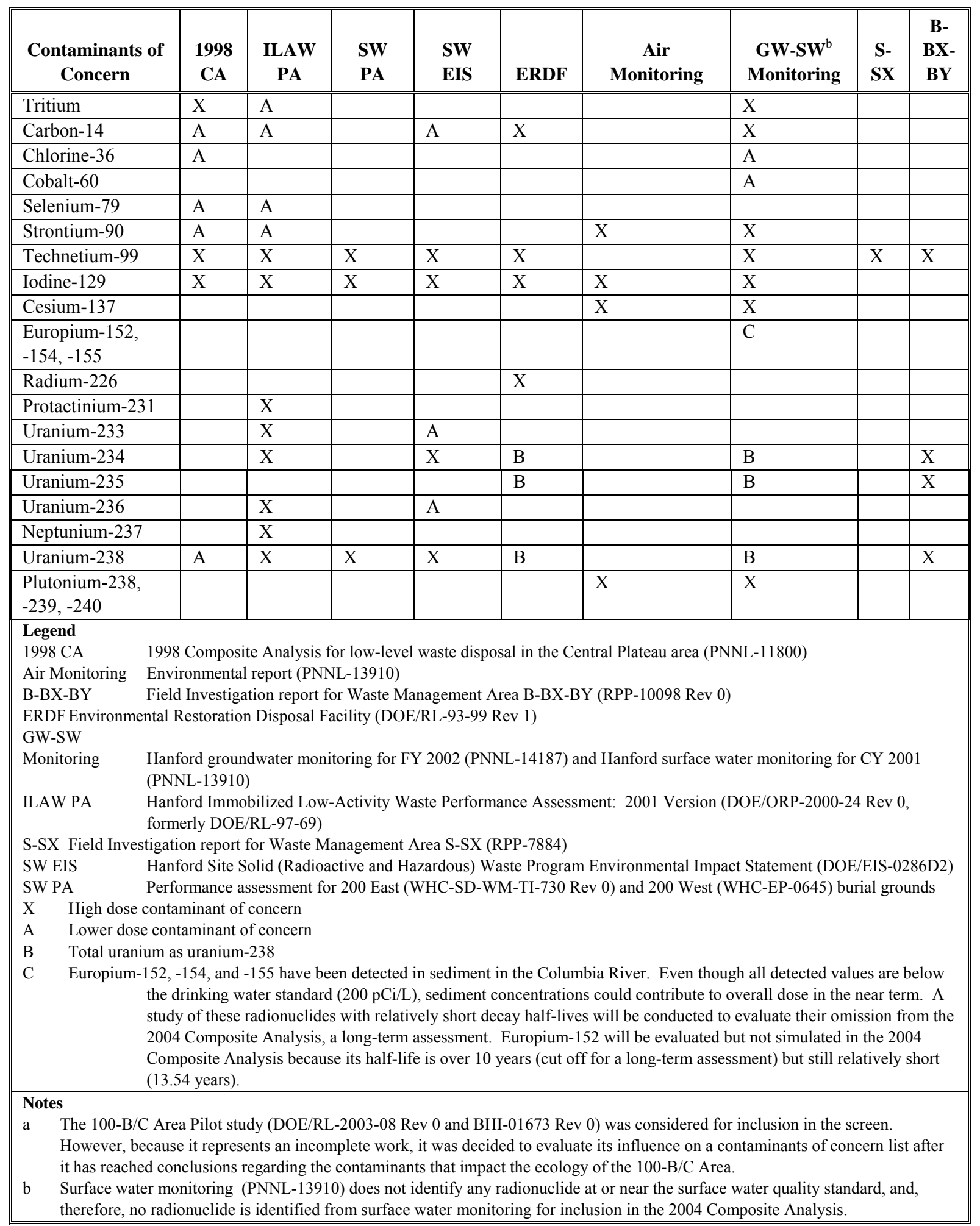


list of contaminants of concern for the planned analysis. This evaluation developed a number of criteria to assist in determining if an analyte should be considered a contaminant of concern for the 2004 Composite Analysis. Criteria identified for the evaluation included detection limits, possible rejection of certain results based on other analytical considerations, half-life, observations relative to drinking water standards, and the spatial/ and temporal distribution of constituents considered.

The Hanford Environmental Information System (HEIS) database was used as the source of sampling data for the analysis. Only groundwater monitoring data from 1990 to December 2002 were included because of the confidence in field sampling methods and laboratory measurements since 1990. Analytical results showing concentrations above detection levels that did not have reject qualifiers were retained for further analysis.

Table A.3 shows the list of constituents in HEIS that groundwater samples have been analyzed for with values above the detection limit and no reject criteria, ranked by half-life. Of the constituents listed, only radionuclides with half-lives longer than 10 years were selected since the 2004 Composite Analysis is a long-term analysis (from site closure to 1000 years after site closure) that assumes an institutional control of 100 years after site closure. Past assessments have shown that radionuclides with half-lives shorter than 10 years do not contribute significantly to the overall dose to future members of the public through the groundwater pathway beyond the period of institutional control.

Table A.3. Radionuclides of Potential Concern Based on Groundwater Monitoring Data from 1990December 2002 Ranked by Half-Life

\begin{tabular}{|c|c|c|c|c|c|c|}
\hline Contaminant & $\begin{array}{c}\text { Half-Life } \\
\text { (Years) }\end{array}$ & $\begin{array}{c}\text { Minimum } \\
\text { Value (pCi/L) }\end{array}$ & $\begin{array}{c}\text { Maximum } \\
\text { Value } \\
\text { (pCi/L) }\end{array}$ & $\begin{array}{l}\text { No. of } \\
\text { Values }\end{array}$ & $\begin{array}{c}\text { Minimum } \\
\text { Sample } \\
\text { Date }\end{array}$ & $\begin{array}{c}\text { Maximum } \\
\text { Sample } \\
\text { Date }\end{array}$ \\
\hline \multicolumn{7}{|c|}{ Half-Life Over 10 Years } \\
\hline Uranium-238 & 4468000000.0 & -0.017 & 1310 & 1152 & $11 / 26 / 1990$ & $1 / 6 / 2003$ \\
\hline Potassium-40 & 1277000000.0 & 0.969 & 900 & 513 & $8 / 3 / 1990$ & $11 / 12 / 2002$ \\
\hline Uranium-235 & 703800000.0 & -0.023 & 136 & 556 & $8 / 23 / 1991$ & $12 / 26 / 2002$ \\
\hline Uranium-236 & 23420000.0 & 0.712 & 1.88 & 2 & $10 / 1 / 1996$ & $10 / 6 / 1996$ \\
\hline Iodine-129 & 15700000.0 & -90.3 & 86.1 & 2129 & $2 / 14 / 1990$ & $12 / 13 / 2002$ \\
\hline Uranium-234 & 245500.0 & -0.017 & 1120 & 698 & $11 / 26 / 1990$ & $1 / 6 / 2003$ \\
\hline Technetium-99 & 211100.0 & -11.19999981 & 188000 & 6017 & $1 / 2 / 1990$ & $1 / 16 / 2003$ \\
\hline Plutonium-239 & 24110.0 & 0.01 & 916 & 6 & $8 / 9 / 1991$ & $7 / 18 / 1994$ \\
\hline Carbon-14 & 5730.0 & 3.31 & 39600 & 504 & $5 / 8 / 1992$ & $12 / 3 / 2002$ \\
\hline Radium-226 & 1600.0 & 0.029 & 262 & 109 & $3 / 5 / 1991$ & $3 / 6 / 2002$ \\
\hline Nickel-63 & 100.1 & 4.79 & 8.93 & 5 & $12 / 10 / 1997$ & $1 / 16 / 2002$ \\
\hline Plutonium-238 & 87.7 & -0.0254 & 11.6 & 603 & $3 / 1 / 1990$ & $12 / 4 / 1997$ \\
\hline Cesium-137 & 30.1 & -13.39999962 & 2310 & 1385 & $1 / 15 / 1990$ & $4 / 12 / 2001$ \\
\hline Strontium-90 & 28.8 & -3.67 & 26000 & 2468 & $1 / 3 / 1990$ & $12 / 18 / 2002$ \\
\hline Tritium & 12.3 & -1230 & 8380000 & 13747 & $1 / 2 / 1990$ & $1 / 6 / 2003$ \\
\hline
\end{tabular}


Table A.3. (contd)

\begin{tabular}{|c|c|c|c|c|c|c|}
\hline Contaminant & $\begin{array}{l}\text { Half-Life } \\
\text { (Years) }\end{array}$ & $\begin{array}{c}\text { Minimum } \\
\text { Value }(p C i / L)\end{array}$ & $\begin{array}{l}\text { Maximum } \\
\text { Value } \\
\text { (pCi/L) }\end{array}$ & $\begin{array}{l}\text { No. of } \\
\text { Values }\end{array}$ & $\begin{array}{c}\text { Minimum } \\
\text { Sample } \\
\text { Date }\end{array}$ & $\begin{array}{c}\text { Maximum } \\
\text { Sample } \\
\text { Date }\end{array}$ \\
\hline \multicolumn{7}{|c|}{ Half-Life Under 10 Years } \\
\hline Europium-154 & 8.6 & -38.09999847 & 24.9 & 333 & $8 / 3 / 1990$ & $9 / 24 / 1996$ \\
\hline Radium-228 & 5.8 & 0.553 & 81 & 16 & $2 / 27 / 1991$ & $11 / 2 / 2000$ \\
\hline Cobalt- 60 & 5.3 & -16.2 & 732 & 1893 & $1 / 3 / 1990$ & $12 / 13 / 2002$ \\
\hline Europium-155 & 4.8 & -17.5 & 13.80000019 & 313 & $8 / 3 / 1990$ & $9 / 24 / 1996$ \\
\hline Antimony-125 & 2.8 & -48.09999847 & 116 & 1468 & $2 / 6 / 1990$ & $9 / 24 / 1996$ \\
\hline Cesium-134 & 2.1 & -12.4 & 11 & 331 & $8 / 3 / 1990$ & $9 / 24 / 1996$ \\
\hline Thorium-228 & 1.9 & 9.4 & 37 & 13 & $12 / 9 / 1991$ & $11 / 2 / 2000$ \\
\hline Ruthenium-106 & 1.0 & -167 & 316 & 1472 & $1 / 4 / 1990$ & $9 / 24 / 1996$ \\
\hline $\begin{array}{l}\text { Cerium/ } \\
\text { Praseodymium- } \\
144\end{array}$ & 0.8 & -175 & 134 & 308 & $8 / 3 / 1990$ & $9 / 22 / 1994$ \\
\hline Zinc-65 & 0.7 & -44.70000076 & 34.90000153 & 312 & $8 / 3 / 1990$ & $2 / 10 / 1995$ \\
\hline $\begin{array}{l}\text { Zirconium/ } \\
\text { Niobium-95 }\end{array}$ & 0.2 & -385 & 720 & 308 & $8 / 3 / 1990$ & $12 / 15 / 1994$ \\
\hline Beryllium-7 & 0.1 & -2420 & 7240 & 326 & $8 / 3 / 1990$ & $9 / 24 / 1996$ \\
\hline Strontium-89 & 0.1 & 56.4 & 2390 & 3 & $9 / 9 / 1996$ & $12 / 4 / 1996$ \\
\hline Iron-59 & 0.1 & 20.8 & 20.8 & 1 & $7 / 18 / 1994$ & $7 / 18 / 1994$ \\
\hline Cerium-141 & 0.1 & 16.7 & 16.7 & 1 & $7 / 17 / 1995$ & $7 / 17 / 1995$ \\
\hline Chromium-51 & 0.1 & 121 & 121 & 1 & $8 / 16 / 1994$ & $8 / 16 / 1994$ \\
\hline Lead-212 & 0.0 & 4.019999981 & 12.6 & 10 & $10 / 16 / 1990$ & $1 / 25 / 1999$ \\
\hline Lead-214 & 0.0 & 16.4 & 87.4 & 4 & $1 / 17 / 1996$ & $3 / 19 / 1996$ \\
\hline
\end{tabular}

Table A.4 is a list of the contaminants retained for inclusion in the 2004 Composite Analysis after applying the detection, reject, half-life criteria. The contaminants are organized in descending order of the value of the ratio of maximum observed concentration in groundwater to the drinking water standard. The drinking water standard is 4 millirem/year for beta and photon emitters, 5 pico curies/liter for the alpha emitters radium-226 and radium-228 combined, 15 pico curies/liter for all other alpha emitting radionuclides excluding uranium (such as, plutonium isotopes), and 27 pico curies/liter for uranium isotopes. 
Table A.4. Radionuclides and Their Drinking Water Standards

\begin{tabular}{|c|c|c|c|c|c|c|c|c|c|c|}
\hline $\begin{array}{l}\text { Contaminants } \\
\text { of Concern }\end{array}$ & $\begin{array}{l}\text { Half-Life } \\
\text { (year) }\end{array}$ & $\begin{array}{c}\text { DWS } \\
(\mathrm{pCi} / \mathrm{L})\end{array}$ & $\begin{array}{l}\text { Reference for } \\
\text { DWS }\end{array}$ & $\begin{array}{c}\text { Minimum } \\
\text { Value } \\
(\mathrm{pCi} / \mathrm{L})\end{array}$ & $\begin{array}{c}\text { Maximum } \\
\text { Value } \\
\text { (pCi/L) }\end{array}$ & $\begin{array}{c}\text { Number } \\
\text { of } \\
\text { Values }\end{array}$ & $\begin{array}{l}\text { Minimum } \\
\text { Sample } \\
\text { Date }\end{array}$ & $\begin{array}{l}\text { Maximum } \\
\text { Sample } \\
\text { Date }\end{array}$ & $\begin{array}{l}\text { Ratio of } \\
\text { Maximum } \\
\text { Value to } \\
\text { DWS }\end{array}$ & Notes \\
\hline Strontium-90 & 28.8 & 8 & NIPDWR & -3.67 & 26000 & 2468 & $1 / 3 / 1990$ & $12 / 18 / 2002$ & 3250 & \\
\hline Tritium & 12.3 & 20000 & NIPDWR & -1230 & 8380000 & 13747 & $1 / 2 / 1990$ & $1 / 6 / 2003$ & 419 & \\
\hline $\begin{array}{l}\text { Technetium- } \\
99\end{array}$ & 211100.0 & 900 & NIPDWR & -11.19999981 & 188000 & 6017 & $1 / 2 / 1990$ & 1/16/2003 & 209 & \\
\hline Iodine-129 & 15700000.0 & 1 & NIPDWR & -90.3 & 86.1 & 2129 & 2/14/1990 & $12 / 13 / 2002$ & 86 & \\
\hline Plutonium-239 & 24110.0 & 15 & $\begin{array}{l}\text { EPAD9283.1- } \\
14\end{array}$ & 0.01 & 916 & 6 & 8/9/1991 & 7/18/1994 & 61 & $\begin{array}{l}\text { Max value occurred in } \\
1994 \text { at one well (299- } \\
\text { E28-23) and all other } \\
\text { wells are more than } 10 \mathrm{X} \\
\text { lower than DWS }\end{array}$ \\
\hline Radium-226 ${ }^{\mathrm{b}}$ & 1600.0 & 5 & NPDWS & 0.029 & 262 & 109 & $3 / 5 / 1991$ & $8 / 26 / 1991$ & 52 & $\begin{array}{l}\text { Max values occurred in } \\
\text { early 1990s, current } \\
\text { values are more than } \\
10 \text { X lower than DWS. }\end{array}$ \\
\hline Uranium-238 & 4468000000.0 & 27 & $\begin{array}{l}\text { EPAD9283.1- } \\
14\end{array}$ & -0.017 & 1310 & 1152 & 11/26/1990 & $1 / 6 / 2003$ & 49 & \\
\hline Uranium-234 & 245500.0 & 27 & $\begin{array}{l}\text { EPAD9283.1- } \\
14\end{array}$ & -0.017 & 1120 & 698 & $11 / 26 / 1990$ & $1 / 6 / 2003$ & 41 & $\begin{array}{l}\text { Run in SAC as part of } \\
\text { U-238 }\end{array}$ \\
\hline Carbon-14 & 5730.0 & 2000 & NIPDWR & 3.31 & 39600 & 504 & $5 / 8 / 1992$ & $12 / 3 / 2002$ & 20 & \\
\hline Cesium-137 & 30.1 & 200 & NIPDWR & -13.39999962 & 2310 & 1385 & 1/15/1990 & $4 / 12 / 2001$ & 12 & \\
\hline Uranium-235 & 703800000.0 & 27 & $\begin{array}{l}\text { EPAD9283.1- } \\
14\end{array}$ & -0.023 & 136 & 556 & 8/23/1991 & 12/26/2002 & 5 & $\begin{array}{l}\text { Run in SAC as part of } \\
\text { U-238 }\end{array}$ \\
\hline Potassium- $40^{\mathrm{C}}$ & 1277000000.0 & 240 & NPDWS & 0.969 & $<200$ & 513 & 8/3/1990 & 4/11/1996 & $<1$ & $\begin{array}{l}\text { Potassium- } 40 \text { is not part } \\
\text { of materials production } \\
\text { legacy, however, it is a } \\
\text { constituent in natural } \\
\text { potassium. }\end{array}$ \\
\hline
\end{tabular}


Table A.4. (contd)

\begin{tabular}{|c|c|c|c|c|c|c|c|c|c|c|}
\hline $\begin{array}{c}\text { Contaminants } \\
\text { of Concern }\end{array}$ & $\begin{array}{c}\text { Half-Life } \\
\text { (year) }\end{array}$ & $\begin{array}{c}\text { DWS } \\
(p C i / L)\end{array}$ & $\begin{array}{c}\text { Reference for } \\
\text { DWS }\end{array}$ & $\begin{array}{c}\text { Minimum } \\
\text { Value } \\
\text { (pCi/L) }\end{array}$ & $\begin{array}{c}\text { Maximum } \\
\text { Value } \\
\text { (pCi/L) }\end{array}$ & $\begin{array}{c}\text { Number } \\
\text { of } \\
\text { Values }\end{array}$ & $\begin{array}{c}\text { Minimum } \\
\text { Sample } \\
\text { Date }\end{array}$ & $\begin{array}{c}\text { Maximum } \\
\text { Sample } \\
\text { Date }\end{array}$ & $\begin{array}{l}\text { Ratio of } \\
\text { Maximum } \\
\text { Value to } \\
\text { DWS }\end{array}$ & Notes \\
\hline Plutonium-238 & 87.7 & 15 & EPAD9283.1-14 & -0.0254 & 11.6 & 603 & 3/1/1990 & 8/29/1994 & 0.8 & $\begin{array}{l}\text { Maximum value occurred in } \\
1994 \text { at one well (299-E28- } \\
25) \text {. Wells } 299-E 28-24 \text { and } \\
23 \text { have value within } 10 \text { X of } \\
\text { DWS and all other wells are } \\
\text { more than } 10 \text { X lower than } \\
\text { DWS }\end{array}$ \\
\hline Nickel-63 & 100.1 & 50 & NIPDWR & 4.79 & 8.93 & 5 & 12/10/1997 & $10 / 4 / 2000$ & 0.18 & $\begin{array}{l}\text { Maximum value occurred in } \\
2000 \text { at one well (699-13- } \\
\text { 3A) and all other wells are } \\
\text { more than } 10 \text { X lower than } \\
\text { DWS }\end{array}$ \\
\hline Uranium-236 & 23420000.0 & 27 & EPAD9283.1-14 & 0.712 & 1.88 & 2 & 10/1/1996 & 10/6/1996 & 0.07 & $\begin{array}{l}\text { Maximum value occurred in } \\
1996 \text { at one well (699-37- } \\
47 \mathrm{~A}) \text { and all other wells are } \\
\text { more than } 10 \mathrm{X} \text { less than } \\
\text { DWS }\end{array}$ \\
\hline $\begin{array}{l}\text { Legend } \\
\text { DWS Drinking w } \\
\text { pCi/L pico curies/ } \\
\text { SAC System Ass } \\
\text { EPAD9283.1-14 } \\
\text { NIPDWR } \\
\text { NPDWS } \\
\text { a } \quad \text { Plutonium- } \\
\text { b } \quad \text { Radium-22 } \\
\text { c } \\
\end{array}$ & $\begin{array}{l}\text { ater standard } \\
\text { liter } \\
\text { essment Capabili } \\
\text { "Use of Uraniun } \\
\text { Directive 9283. } \\
\text { National Interim } \\
\text { National Primar } \\
240 \text { is approxima } \\
\text { contaminant of } \\
5 \text { and radium-228 } \\
\text { vels observed at } F \\
\text { therefore, the bo } \\
\text { review, values g } \\
\text { using the new d } \\
\text { day, and an inge }\end{array}$ & $\begin{array}{l}\text { rinking W } \\
4 \text { (http://wy } \\
\text { rimary Drin } \\
\text { Orinking W } \\
6 \% \text { by ma } \\
\text { icern, then } \\
\text { ve a combi } \\
\text { ford are as } \\
\text { is not influ } \\
\text { ter than } 20 \\
\text { king water } \\
\text { on dose cor }\end{array}$ & $\begin{array}{l}\text { er Standards under } 4 \text { ( } \\
\text { w.epa.gov/superfund/ } \\
\text { ing Water Regulatior } \\
\text { er Standards } 40 \text { CFR } \\
\text { s of the plutonium in } \\
\text { lutonium-240 would } \\
\text { ed Drinking Water St } \\
\text { siated with the insitu } \\
\text { nced by variations in } \\
\text { pCi/L were suspect, } \\
\text { gulation proposed by } \\
\text { ersion factor of } 2.291\end{array}$ & $\begin{array}{l}\text { CFR } 141 \text { and } 4 \\
\text { esources/radiati } \\
\text { (EPA-570/9-7 } \\
141.66 \text { (http://w } \\
\text { entory and acco } \\
\text { e simulated also } \\
\text { indard of } 5 \text { pico } \\
\text { redox manipula } \\
\text { environmental le } \\
\text { epresented a nol } \\
\text { the U.S. EPA, tl } \\
+05 \text { mrem/pCi. }\end{array}$ & $\begin{array}{l}\text { CFR } 192 \text { as Re } \\
\text { adf/9283_1_1 } \\
\text { 003) } \\
\text { w.epa.gov/safe } \\
\text { ingly is present } \\
\text { If plutonium-2. } \\
\text { uries/liter. } \\
\text { on to control ch } \\
\text { els (Eisenbud } 1 \\
\text { tandard water } \\
\text { committed effe } \\
\text { he new drinkir }\end{array}$ & $\begin{array}{l}\text { ater/mcl.htm } \\
\text { where pluton } \\
9 \text { is not a con } \\
\text { omium migro } \\
87 \text { ). } \text { Merri } \\
\text { ample, or we } \\
\text { tive dose eq } \\
\text { water regul }\end{array}$ & $\begin{array}{l}\text { \#mcls). } \\
\text { um-239 is obse } \\
\text { aminant of con } \\
\text { ion. The body } \\
\text { Eisenbud, Env } \\
\text { e not confirme } \\
\text { ivalent of } 4 \mathrm{mr} \\
\text { tion is } 40 \mathrm{CFR}\end{array}$ & $\begin{array}{l}\text { ved, but at low } \\
\text { ern, then plutor } \\
\text { egulates potass } \\
\text { ronmental Radi } \\
\text { by a second sar } \\
\mathrm{m} / \mathrm{yr} \text { from an a } \\
141.66 \text {. }\end{array}$ & $\begin{array}{l}\text { sites" Novemb } \\
\text { evels. If plutol } \\
\text { ium- } 240 \text { would } \\
\text { um in the body } \\
\text { oactivity. } 1987 \\
\text { ple. A potassi } \\
\text { mual intake of }\end{array}$ & $\begin{array}{l}\text { 6, 2001. EPA OSWER } \\
\text { ium-239 were determined to be a } \\
\text { not be one either. } \\
\text { preventing a buildup, and, } \\
\text { Academic Press, pg } 149 .\} \text { Upon } \\
\text { Im-40 limit has been calculated } \\
\text { wo liters of drinking water per }\end{array}$ \\
\hline
\end{tabular}


Groundwater data for these contaminants was examined to determine if the contamination is recent and distributed widely enough to contribute to the impact in a site-wide analysis. Using these criteria, the rationale for eliminating the following contaminants is:

- Potassium-40 is not part of nuclear materials production legacy at the Hanford Site and is a constituent in natural potassium.

- Nickel-63 maximum value occurred in well 699-13-3A. All other field observations are less than one-tenth the drinking water standard.

- Radium-226 maximum values occurred in the early 1990s. Current values are less than one-tenth of the drinking water standard.

- Uranium-236 maximum value occurred in 1996 at a well near the southeast corner of the 200 East Area and all other wells are less than a tenth of the drinking water standard. In addition, uranium-236, when simulated, has been found to be only a minor contributor to dose.

- Plutonium-238 maximum value occurred in 1994 in well 229-E28-25. This and other wells in the immediate vicinity of the 216-B-5 reverse well exhibit the high values, while all other field observations are less than one-tenth the DWS.

- Plutonium-239 maximum value occurred in 1994 at one well (299-E28-23). Values from all other wells are less than one tenth of the drinking water standard. The 299-E28-23 monitoring well is in the immediate vicinity of the $216-\mathrm{B}-5$ reverse well, a deep vadose zone disposal facility known to have received waste containing plutonium during B Plant's bismuth phosphate operation. The plutonium was shown to be strongly sorbed onto sediment when a pump and treat remedial action was undertaken and halted because of its ineffectiveness.

Contaminants selected for further consideration in the 2004 Composite Analysis are in bold type in Table A.4. These contaminants of concern are currently present in groundwater, and they include tritium, carbon-14, strontium-90, technetium-99, iodine-129, cesium-137, and uranium isotopes 234,235 , and 238.

The 2004 Composite Analysis is required to examine all pathways of exposure to an off site individual, and, therefore, will consider the air and surface water exposure pathways as well as the groundwater pathway. Surface water monitoring data from 2002 indicate all contaminant levels are well below drinking water standards and derived concentration guides. In the case of the surface water exposure pathway however, all contaminants being modeled for the groundwater pathway have the potential to enter the Columbia River. Therefore, all contaminants of concern in the groundwater pathway are included ultimately on the contaminant of concern list for the surface water pathway.

During the workshop on February 25, 2003 environmental monitoring staff indicated that there was interest in europium isotopes in outfall structures for 100 Area sites and in Columbia River sediment. The half-lives of europium-152/154/155 are 13.54, 8.593, and 4.75 years respectively. Thus, 
europium-154 and europium-155 can be eliminated based on the minimum 10-year half-life because they do not present a long-term threat in post-closure analyses. Europium-152 has a half-life greater than 10 years and has been detected in sediment in the Columbia River. All detected values are below drinking water standards (200 pico curies/liter), but sediment concentrations may have an impact on dose that could contribute to the overall dose from the Hanford Site. A study of europium-152 will be conducted and reported in the 2004 Composite Analysis to further evaluate its role in long-term risk and impact. However, because of its relatively short decay half-life, europium-152 is not envisioned to play a substantial role in long-term risk and will not be simulated in the 2004 Composite Analysis.

The discussion to this point has been associated with constituents associated with past and current groundwater and surface water monitoring data to define the contaminants of concern for the 2004 Composite Analysis. Results of past monitoring is useful when identifying contaminants of concern for these pathways because much of the material discharged to Hanford's waste sites remains in the waste site or the soil and groundwater adjacent to the site and so can provide insight into what may continue to be a contaminant in the future for groundwater and surface water. Contaminants discharged to the air in the past, however, have generally disbursed beyond the Hanford Site and resulted from activities that will not continue into the future, such as air emissions during fuel manufacturing, reactor operations, and extraction of plutonium from irradiated fuel. Therefore, past monitoring results do not provide the same basis for selecting contaminants of concern for estimating the future impact for air transport as they do for the groundwater pathway.

Two radionuclides are anticipated to release to the air pathway in quantities that could contribute to an offsite dose to the public. Carbon-14 is a volatile radionuclide. The graphite reactor cores contain sufficient inventories of carbon-14 that its potential to contribute to an offsite public dose needs to be assessed. In addition, iodine-129 is volatile, has a long half-life and will be included in the air pathway analysis. While not potential long-term air pathway contaminants, several contaminants in addition to carbon-14 and iodine-129 were monitored during Hanford operations and represent candidates for history matching efforts for the air model. They include krypton-85, strontium-90, cesium-137, and plutonium-239/240.

The participants in the February 25, 2003 workshop suggested that while past environmental monitoring results are useful in identifying contaminants of concern for the 2004 Composite Analysis, radionuclides may exist that have not yet released from waste sites but will in the future. Table A.2 lists contaminants to be considered based on predictions in the immobilized low-activity waste (ILAW) performance assessment (DOE/ORP-2000-24 Rev 0), solid waste performance assessments (WHC-SD-WM-TI-730, WHC-EP-0645), solid waste EIS (DOE/EIS-0286D2), ERDF (DOE/RL-93-99), S-SX (RPP-7884), and B-BX-BY (RPP-10098 Rev 0) studies of the contaminants' future impact. Previous assessments were reviewed to identify contaminants that have not been observed in groundwater and those that were eliminated through the screening of monitoring results but that may release in the future. Included are chlorine-36, selenium-79, radium-226, protactinium-231, uranium-233, uranium-236, and neptunium-237. These constituents were investigated to determine if they would be considered contaminants of concern for the 2004 Composite Analysis. 
Radium-226 will be simulated as a uranium progeny and not simulated as a separate radionuclide. An enabling assumption is that radium-226 will move with its parent in the environment. Protactinium-231 will also be simulated as a uranium progeny, and, therefore, included in dose calculations for uranium-235. Uranium-236 was a very minor contributor to the overall dose in the ILAW performance assessment (DOE/ORP-2000-24 Rev 0) and solid waste Environmental Impact Statement (DOE/EIS0286D2) so will be negligible from a site-wide perspective. Therefore, uranium-236 will not be considered a contaminant of concern for the 2004 Composite Analysis.

Because of their appearance in prior assessments, chlorine-36, selenium-79, uranium-233, and neptunium-237 will be considered contaminants of concern for the 2004 Composite Analysis. The potential role of protactinium-231 and radium-226 will be further evaluated and reported in the 2004 Composite Analysis. Because of the potential for the uranium progeny protactinium-231 and thorium progeny radium-226 to be out of equilibrium with their parent in the waste, the relative amounts of protactinium-231 and radium-226 in the waste will be evaluated to determine if their inventories warrant separate treatment in future assessments as contaminants of concern.

Adding the selected constituents that may be of concern in the future to the list of contaminants of concern in Table A.4, a final list of contaminants of concern is defined for the 2004 Composite Analysis. Table 2.1 shows the final list of contaminants of concern and the primary source that included them.

The scope of work for the 2004 Composite Analysis is a radionuclide only analysis. However, a parallel analysis using the System Assessment Capability (SAC) tool will examine a limited list of chemical contaminants of interest. Current plans for the analysis of hazardous chemicals are limited to the continuing analysis of carbon tetrachloride and chromium and a new analysis of the combination of discharges and unplanned releases contributing to the nitrate groundwater plume. Discharges that contribute to the nitrate plumes in groundwater include the contaminants ammonia, nitrate, and nitrite. Initially, these analyses will be limited to those sites for which the Hanford Soil Inventory Model (SIM) provides inventory estimates and the Hanford Tank Waste Operation Simulator (HTWOS) model provides inventory estimates for tank farm releases to the environment.

These three contributors to nitrate contamination will be modeled either as an equivalent quantity of nitrate or as separate contaminants and combined in a post processing step. Simulation of the degradation of ammonia to nitrite, and nitrite to nitrate will not be undertaken within the vadose zone and groundwater models. Other simplifications may be required to address the human health risk and ecological impact of nitrate.

\section{Current and Potential Land Use}

The current and potential use of the land in the immediate vicinity of the Hanford Site is summarized in Table A.5. Table A.5 is based on the Central Plateau Risk Framework presented in a letter from DOE, EPA and Ecology to the Hanford Advisory Board (Appendix C of DOE/RL-2002-59). The multiple land uses on the interior of the Hanford Site will include Residential Farmer and Native American use scenarios. Scenarios applied to the lands of the Hanford Reach National Monument will include a ranger, Native American user, Residential Farmer, and casual and avid recreational users. Figure 1.1 shows the 
location of the Columbia River, areas designated as the Core Zone and Central Plateau of the Hanford Site, and Hanford Reach National Monument, which are the cleanup areas denoted in the table. Land use information is needed for the DQO process to support the evaluation of when and where specific land use and hence exposure scenarios are applied and the evaluation of the consequences of decision errors.

Table A.5. Potential Land Use and Time Frame

\begin{tabular}{|c|c|c|c|}
\hline Time Frame & Core Zone & $\begin{array}{c}\text { Beyond Core } \\
\text { Zone }\end{array}$ & $\begin{array}{l}\text { Hanford Reach } \\
\text { National Monument } \\
\text { and Columbia River }\end{array}$ \\
\hline $2000-2012$ & DOE Cleanup & DOE Cleanup & DOE Cleanup \\
\hline $2012-2035$ & DOE Cleanup & DOE Cleanup & $\begin{array}{l}\text { Recreational Use and } \\
\text { Native American } \\
\text { Scenario with } \\
\text { Groundwater }\end{array}$ \\
\hline $2035-2150$ & $\begin{array}{l}\text { Restricted } \\
\text { Industrial Land } \\
\text { Use, No } \\
\text { Groundwater } \\
\text { Use }\end{array}$ & $\begin{array}{l}\text { Restricted Land } \\
\text { Use, No } \\
\text { Groundwater } \\
\text { Use }\end{array}$ & $\begin{array}{l}\text { Recreational Use and } \\
\text { Native American } \\
\text { Scenario with } \\
\text { Groundwater }\end{array}$ \\
\hline $2150-X X$ & $\begin{array}{l}\text { Restricted } \\
\text { Industrial Land } \\
\text { Use, } \\
\text { Groundwater } \\
\text { Use Cases for } \\
\text { Information Only }\end{array}$ & $\begin{array}{l}\text { Multiple Land } \\
\text { Uses, } \\
\text { Groundwater } \\
\text { Use Cases for } \\
\text { Information Only }\end{array}$ & $\begin{array}{l}\text { Recreational Use and } \\
\text { Native American } \\
\text { Scenario with } \\
\text { Groundwater }\end{array}$ \\
\hline $\mathrm{XX}$ to 12050 & $\begin{array}{l}\text { Restricted } \\
\text { Industrial Land } \\
\text { Use, } \\
\text { Groundwater } \\
\text { Use Cases for } \\
\text { Information Only }\end{array}$ & $\begin{array}{l}\text { Multiple Land } \\
\text { Uses Simulated } \\
\text { Using } \\
\text { Groundwater }\end{array}$ & $\begin{array}{l}\text { Recreational Use and } \\
\text { Native American } \\
\text { Scenario with } \\
\text { Groundwater }\end{array}$ \\
\hline \multicolumn{4}{|c|}{$\begin{array}{l}\text { XX The time after which the groundwater quality of the unconfined and confined } \\
\text { aquifers under the Hanford Site have returned to potable water quality, and the } \\
\text { aquifers become a viable water supply. }\end{array}$} \\
\hline
\end{tabular}




\section{Conceptual Site Model}

Figure A.1 shows a conceptual model of waste inventory, environmental transport pathways and receptors at the Hanford Site. More detailed conceptual models for each element of the transport pathway and for each receptor type are available at http:/www.hanford.gov/cp/gpp/modeling/sacarchive.cfm (Bechtel 1999).

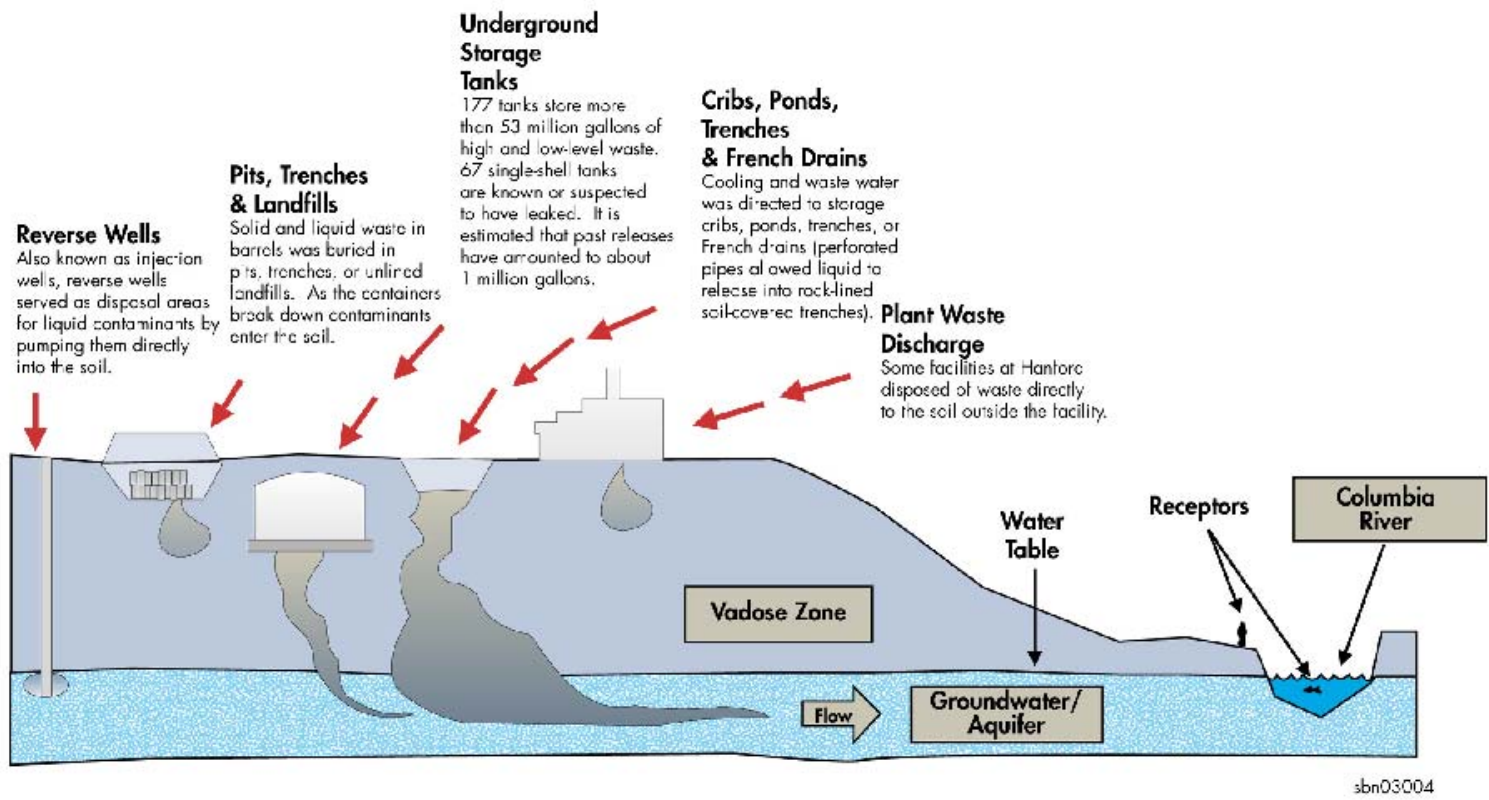

Figure A.1. Conceptual Model of Waste Inventory, Environmental Transport Pathways and Receptors at the Hanford Site

\section{Step 2: Identify Decisions}

The purpose of DQO Step 2 is to define the principal study questions that need to be resolved to address the problem identified in DQO Step 1 and the alternative actions that would result from the resolution of the principal study questions. The principal study questions and alternative actions are then combined into decision statements that express a choice among alternative actions. This section provides the principal study questions for the 2004 Composite Analysis and resulting decision statements.

A range of decisions must be made based on the results of the predicted dose to a hypothetical future member of the public during the 1000-year period following closure of the Hanford Site. If the maximum predicted dose is greater than 100 millirem/year in any year, then an options analysis and ALARA (as low as reasonably achievable) assessment is performed and actions (determined by the options analysis) are taken to reduce the predicted dose below 100 millirem in a year and ALARA (as determined by the ALARA assessment). If the maximum predicted dose is greater than 30 millirem in a year but less than 100 millirem in a year, then an options analysis and ALARA assessment are performed to identify the 
most effective actions that could be taken to reduce the predicted maximum dose. However, an alternate action is only recommended if it is feasible and beneficial considering economic, social-cultural, and ecological-resource factors. If the maximum predicted dose is below 30 millirem in a year, then a screening-type ALARA assessment that weighs the cost of the options analysis and the potential benefit of dose reduction is performed to determine if a full options analysis and ALARA assessment is warranted.

- The primary question is: Can DOE continue to dispose of low-level radioactive waste at the Hanford Site without an unacceptable impact to the off site public (based on DOE Order 435.1) for the 1000 -year regulatory analysis following site closure?

- A secondary question is: How can DOE most effectively accomplish the cleanup at the Hanford Site given the multiple sources of contaminants contributing to a composite impact on groundwater and potentially human and ecological health?

Principal Study Question \#1 - Does the cumulative Effective Dose Equivalent associated with the disposal waste sites at the Hanford Site exceed 30 millirem/year but remain below 100 millirem/year? If it does not exceed 30 millirem/year, then alternative action \#1 applies. If it does exceed 30 millirem/year, then alternative action $\# 2$ applies.

- Alternative Action \#1: Take no Action

- Alternative Action \#2: Perform an options analysis and ALARA assessment and evaluate whether action is economically viable to reduce all pathways exposure and dose to future generations. If viable, take the action to reduce exposure and dose.

Decision Statement \#1 - Determine whether a future member of the public is safe from the radioactive waste disposed of at the Hanford Site based on DOE Order 435.1 and if it is economically viable to further reduce exposure and dose to future generations or no further action is required.

Principal Study Question \#2 - Does the cumulative Effective Dose Equivalent associated with the disposal waste sites at the Hanford Site exceed 100 millirem/year? If it does not, then alternative action \#1 applies and Principal Study Question \#1 has addressed the issue. If it does exceed 100 millirem/year, then alternative action \#2 applies.

- Alternative Action \#1: Take no action unless it exceeds 30 millirem/year in which case Principal Study Question \#1 is addressed.

- Alternative Action \#2: Perform an options analysis and ALARA assessment and take the actions to reduce the predicted dose below 100 millirem in a year.

Decision Statement \#2 - Determine whether a future member of the public is at risk from the radioactive waste disposed of at the Hanford Site based on DOE Order 435.1 and, if so, what actions need to be taken 
to ensure safety to the public or that the actions taken in response to Principle Study Question \#1 adequately address the issue or that no action is required.

Additional study questions have come out of discussions with the DQO team and are included below for consideration during the performance and interpretation of the 2004 Composite Analysis:

- Which radioactive contaminants of concern are the primary contributors to the cumulative Effective Dose Equivalent?

- Which chemical contaminants of concern are the primary contributors to the cumulative risk?

- Which disposal waste sites are the primary contributors to the cumulative Effective Dose Equivalent?

- Which components (such as inventory, release rates, transport, and exposure) of the analysis contribute most to the magnitude and uncertainty of the results?

\section{Step 3: Identify Key Data for Analysis}

This section identifies the key data needed for each element of the 2004 Composite Analysis and identifies the information needed for an initial list of waste sites to be included in the analysis. As the list of waste sites becomes more refined, additional sites may be added to the list.

In general the following information is needed to analyze the composite impact from radiological waste that will remain at Hanford:

- Inventory data - total and waste-site specific activity of each radionuclide that could contribute to the calculated composite dose

- Release model information and parameters - chemical and physical form of waste, release mechanism (such as, dissolution, diffusion, and corrosion)

- Release model parameters - water flux through waste site, dissolution rates, distribution coefficients, diffusion coefficients, temperature

- Vadose zone water movement model parameters - depth of waste, cover type and integrity, recharge rate, geohydrologic profile, unsaturated hydraulic properties

- Vadose zone contaminant transport - saturated porosity, moisture content, distribution coefficients, bulk density, existing vadose zone plumes or contaminant profiles

- Groundwater model parameters and assumptions - upland groundwater and Columbia River boundaries, geohydrologic units, hydraulic properties, recharge rates

- Groundwater transport parameters - porosity, distribution coefficients, existing groundwater plumes

- Columbia River model flow parameters and assumptions including the river cross sections, roughness coefficients, and upstream flow rates

- Columbia River transport parameters including turbulent mixing coefficients, and sedimentcontaminant distribution coefficients

- Exposure scenario assumptions and parameters - future land use, location of the boundary where public access is assumed

- Atmospheric contaminant transport parameters and assumptions including wind speed and direction, current weather and air temperature. 
More specific key data are listed in the tables in the following sections.

\section{Key Variables}

Key variables needed to represent

- Contaminant inventory at each waste site are shown in Table A.6

- Contaminant release from each waste type are shown in Table A.7

- Contaminant transport in the atmosphere are shown in Table A.8

- Contaminant transport in the vadose zone and flow are shown in Table A.9

- Contaminant transport in Groundwater are shown in Table A.10

- Contaminant concentrations in the river shore environment are shown in Table A.11

- Contaminant transport in the Columbia River and flow are shown in Table A.12

- Contaminant impact on human health are shown in Table A.13

- Contaminant impact on ecological species are shown in Table A.14. 
Table A.6. Key Variables for Waste Site Inventory

\begin{tabular}{|l|l|l||}
\hline \multicolumn{1}{|c|}{ Variable } & \multicolumn{1}{|c|}{ Units } & \multicolumn{1}{|c||}{ Dependency } \\
\hline Volume of a waste stream & meters ${ }^{3}$ & T, W \\
\hline Concentration of a contaminant in a waste stream & $\begin{array}{l}\text { curies } / \text { meter }^{3} \text { or } \\
\text { kilograms } / \text { meter }^{3}\end{array}$ & T, W, C \\
\hline Site total for a contaminant & $\begin{array}{l}\text { curies or } \\
\text { kilograms }\end{array}$ & T, C \\
\hline $\begin{array}{l}\text { Fraction of import or waste amount going to a release } \\
\text { location }\end{array}$ & None & T, L, W \\
\hline $\begin{array}{l}\text { C contaminant } \\
\text { L location } \\
\text { T time } \\
\text { W waste stream }\end{array}$ & \\
\hline
\end{tabular}

Table A.7. Key Variables for Contaminant Release from Each Waste Type

\begin{tabular}{|c|c|c|c|c|}
\hline Symbol & Variable & Units & Dependency & $\begin{array}{c}\text { Applicable Waste } \\
\text { Form }\end{array}$ \\
\hline \multirow[t]{6}{*}{$\mathrm{K}_{\mathrm{d}}$} & Soil partition coefficient & $\begin{array}{l}\text { meters }^{3} \\
\text { aqueous/kilogram solid }\end{array}$ & $\mathrm{C}, \mathrm{M}, \mathrm{T}$ & Soil debris \\
\hline & $\begin{array}{l}\text { Contaminant aqueous } \\
\text { solubility }\end{array}$ & $\begin{array}{l}\text { kilograms solid } / \text { meter }^{3} \\
\text { aqueous }\end{array}$ & $\mathrm{C}, \mathrm{M}, \mathrm{T}$ & Soil debris \\
\hline & Dissolution rate & meters/second & $\mathrm{M}, \mathrm{T}$ & Cake/sludge, glass \\
\hline & Diffusion rate & meters $^{2} /$ second $^{2}$ & $\mathrm{C}, \mathrm{M}, \mathrm{T}$ & Cement \\
\hline & Contaminant leach rate & kilograms/meter ${ }^{2} /$ second & & Reactor block \\
\hline & Corrosion rate & kilograms/meter ${ }^{2}$ & $\mathrm{M}, \mathrm{T}$ & Reactor compartment \\
\hline $\begin{array}{ll}\mathrm{C} & \text { contam } \\
\mathrm{M} & \text { matrix } \\
\mathrm{T} & \text { temper }\end{array}$ & $\begin{array}{l}\text { nant } \\
\text { ture }\end{array}$ & & & \\
\hline
\end{tabular}


Table A.8. Key Variables for Contaminant Transport in the Atmosphere

\begin{tabular}{|l|l|l|l||}
\hline \multicolumn{1}{|c|}{ Symbol } & \multicolumn{1}{|c|}{ Variable } & \multicolumn{1}{c|}{ Units } & \multicolumn{1}{|c||}{$\begin{array}{l}\text { Dependency } \\
\text { (Restraints) }\end{array}$} \\
\hline$\theta$ & Surface-level wind direction & degrees & $\mathrm{T}, \mathrm{L}$ \\
\hline $\mathrm{u}$ & Surface-level wind speed & $\mathrm{m} / \mathrm{sec}$ & $\mathrm{T}, \mathrm{L}$ \\
\hline $\mathrm{S}$ & Atmospheric stability class & Dimensionless & $\mathrm{T}, \mathrm{L}$ \\
\hline $\mathrm{wx}$ & Current weather & Dimensionless & $\mathrm{T}, \mathrm{L}$ \\
\hline$\theta$ & wind direction at release height & degrees & $\mathrm{T}, \mathrm{L}$ \\
\hline $\mathrm{u}$ & wind speed at release height & $\mathrm{m} / \mathrm{sec}$ & $\mathrm{T}, \mathrm{L}$ \\
\hline $\mathrm{T}$ & ambient air temperature at release height & degrees & $\mathrm{T}$ \\
\hline $\mathrm{z} 0$ & Surface roughness & $\mathrm{m}$ & $\mathrm{T}, \mathrm{L}$ \\
\hline $\mathrm{L}=$ location & & \\
$\mathrm{T}=$ time & & \\
\hline
\end{tabular}

Table A.9. Key Variables for Flow and Contaminant Transport in the Vadose Zone

\begin{tabular}{|c|c|c|c|c|}
\hline \multicolumn{2}{|c|}{ Symbol } & Variable & Units & $\begin{array}{l}\text { Dependency } \\
\text { (Restraints) }\end{array}$ \\
\hline \multicolumn{2}{|l|}{$\mathrm{Q}_{\mathrm{z}}$} & $\begin{array}{l}\text { Recharge rate (expressed as volume per unit area entering } \\
\text { the upper boundary per unit time) }\end{array}$ & millimeters/year & $\mathrm{T}, \mathrm{L}$ \\
\hline \multicolumn{2}{|l|}{$\mathrm{n}_{\mathrm{T}}$} & Total porosity ${ }^{\mathrm{a}}$ & Dimensionless & $\mathrm{H}$ \\
\hline \multicolumn{2}{|l|}{$\mathrm{S}_{\mathrm{r}}$} & Residual saturation & Dimensionless & $\mathrm{H}$ \\
\hline \multicolumn{2}{|l|}{$\alpha$} & $\begin{array}{l}\text { van Genuchten (1980) soil moisture characteristic } \\
\text { function fitting parameter (inverse of air entry head) }\end{array}$ & meters $^{-1}$ & $\mathrm{H}$ \\
\hline \multicolumn{2}{|l|}{$n$} & $\begin{array}{l}\text { van Genuchten (1980) soil moisture characteristic } \\
\text { function fitting parameter (exponential term) }\end{array}$ & Dimensionless & $\mathrm{H}$ \\
\hline \multicolumn{2}{|l|}{$\mathrm{k}_{\mathrm{m}}$} & Intrinsic permeability (matrix) & meters $^{2}$ & $\mathrm{H}$ \\
\hline \multicolumn{2}{|l|}{$\alpha_{L}$} & Longitudinal dispersivity & meters & $\mathrm{H}$ \\
\hline \multicolumn{2}{|l|}{$\mathrm{K}_{\mathrm{sn}}$} & Solid-aqueous distribution coefficient & $\begin{array}{l}\text { meters }{ }^{3} \text { aqueous/kilogram } \\
\text { solid }\end{array}$ & $\mathrm{C}, \mathrm{H}$ \\
\hline \multicolumn{5}{|c|}{$\begin{array}{l}\text { a The saturated moisture content }\left(\theta_{\mathrm{S}}\right) \text { and residual moisture content }\left(\theta_{\mathrm{R}}\right) \text { parameters are related to porosity values as } \\
\text { follows: } \theta_{\mathrm{S}}=\mathrm{n}_{\mathrm{T}} ; \theta_{\mathrm{R}}=\mathrm{n}_{\mathrm{T}}-\mathrm{n}_{\mathrm{E}} \text {. }\end{array}$} \\
\hline \multicolumn{5}{|c|}{$\mathrm{C}=$ contaminant } \\
\hline \multicolumn{5}{|c|}{ elogic unit } \\
\hline \multicolumn{5}{|c|}{$=$ location } \\
\hline \multicolumn{5}{|c|}{$=$ time } \\
\hline W & $=$ wast & ype & & \\
\hline \multirow{2}{*}{$\begin{array}{l}\mathrm{n}_{\mathrm{T}} \\
\mathrm{n}_{\mathrm{E}}\end{array}$} & $=$ total & prosity & & \\
\hline & $=$ effec & porosity & & \\
\hline
\end{tabular}


The groundwater flow module relies on a model calibrated against hydraulic head and hydraulic conductivity data. Because the calibration represents an optimum model representation given the known hydraulic data, variations in many hydraulic variables would be inconsistent with the model calibration. Hence, the only uncertainty treatment available to the model would be in the form of different calibrated flow fields developed under alternative conceptual models.

The systems code will allow the user to generate or specify a separate alternate conceptual model and associated groundwater flow field for each realization of the simulator.

The groundwater contaminant transport module will handle the variables shown in Table A.10 in a stochastic manner using the CFEST code (the code selected for the groundwater contaminant transport module in SAC).

Table A.10. Key Variable for Contaminant Transport in Groundwater

\begin{tabular}{||l|l|l|l||}
\hline Symbol & \multicolumn{1}{|c|}{ Variable } & \multicolumn{1}{|c|}{ Unit } & Dependency \\
\hline $\mathrm{K}_{\mathrm{d}}$ & Solid-aqueous distribution coefficient & $\begin{array}{l}\text { meters }^{3} \\
\text { aqueous/kilogram } \\
\text { solid }\end{array}$ & $\mathrm{C}$ \\
\hline $\mathrm{C}=$ contaminant & \\
\hline
\end{tabular}

Table A.11. Key Variables for Contaminant Concentrations in the River Shore Environment

\begin{tabular}{||l|l|l|l||}
\hline Symbol & \multicolumn{1}{|c|}{ Description } & \multicolumn{1}{|c||}{ Units } & Dependency \\
\hline D $f_{\text {seep }}$ & $\begin{array}{l}\text { Dilution factor (groundwater concentration to } \\
\text { seepage water concentration) }\end{array}$ & dimensionless \\
\hline D cobble & $\begin{array}{l}\text { Dilution factor (groundwater concentration to } \\
\text { concentration in pore water in river bottom boundary } \\
\text { layer sediment and cobbles) }\end{array}$ & dimensionless \\
\hline $\mathrm{K}_{d \mid \text { sediment }}$ & $\begin{array}{l}\text { Solid-aqueous distribution coefficient (between the } \\
\text { layer sediment and the cobbles and river bottom } \\
\text { sediment) }\end{array}$ & $\begin{array}{l}\text { meters } \\
\text { aqueous/kilogram } \\
\text { solid }\end{array}$ & $\mathrm{C}, \mathrm{L}$ \\
\hline $\mathrm{K}_{d \mid \text { soil }}$ & $\begin{array}{l}\text { Solid-aqueous distribution coefficient (between the } \\
\text { groundwater and the near-river-shore soil) }\end{array}$ & $\begin{array}{l}\text { meters } \\
\text { aqueous/kilogram } \\
\text { solid }\end{array}$ & $\mathrm{C}, \mathrm{L}$ \\
\hline $\begin{array}{l}\mathrm{C}=\text { contaminant } \\
\mathrm{L}=\text { location } \\
\mathrm{T}=\text { time (seasonal) }\end{array}$ & \\
\hline
\end{tabular}


Table A.12. Key Variables for Flow and Contaminant Transport in the Columbia River

\begin{tabular}{||l|l|l|l||}
\hline \multicolumn{1}{|c|}{ Variable } & \multicolumn{1}{|c|}{ Description } & Dependency & Parameter \\
\hline Channel roughness & Effect of resistance on flow & L & L \\
\hline Bed sediment porosity & -- & L & -- \\
\hline Turbulent mixing & Mixing coefficient & L & L \\
\hline $\mathrm{K}_{\mathrm{d}}$ & Sediment-contaminant interaction & C & C \\
\hline Rate coefficient & Rate of sediment-contaminant interaction & C & C \\
\hline $\mathrm{C}=$ contaminant & & \\
$\mathrm{L}=$ location & & \\
\hline
\end{tabular}

Table A.13. Key Variables for Contaminant Impact on Human Health

\begin{tabular}{|c|c|c|c|}
\hline Symbol & Variable & Units $^{a}$ & Dependency \\
\hline Ef & Exposure frequency & days/year & \\
\hline Efboat & Exposure frequency for boating & hours/day & \\
\hline Efriver & Exposure frequency to volatile river water & hours/day & \\
\hline Efsed & Exposure frequency to sediment & hours/day & \\
\hline Efseep & Exposure frequency to volatile seep water & hours/day & \\
\hline Efsoil & Exposure frequency to soil & hours/day & \\
\hline Efswim & Exposure frequency for swimming & hours/day & \\
\hline Efother & Exposure frequency for other & hours/day & \\
\hline Etboat & Exposure time for boating & hours/day & \\
\hline Etriver & Exposure time to volatile river water & hours/day & \\
\hline Etsed & Exposure time to sediment & hours/day & \\
\hline Etseep & Exposure time to volatile seep water & hours/day & \\
\hline Etsoil & Exposure time to soil & hours/day & \\
\hline Etswim & Exposure time for swimming & hours/day & \\
\hline Etother & Exposure time for other & hours/day & \\
\hline Bwchild & Body weight - child & kilograms & \\
\hline Bwadult & Body weight - adult & kilograms & \\
\hline Irate & Inhalation rate & meters ${ }^{3} /$ day & \\
\hline Edchild & Exposure duration - child & years & \\
\hline Edadult & Exposure duration - adult & years & \\
\hline Sasoil & Body surface area for soil & centimeters $^{2}$ & \\
\hline Sased & Body surface area for sediment & centimeters $^{2}$ & \\
\hline Saseep & Body surface area - seep water & centimeters $^{2}$ & \\
\hline Sariver & Body surface area - river water & centimeters $^{2}$ & \\
\hline
\end{tabular}


Table A.13. (contd)

\begin{tabular}{|c|c|c|c|}
\hline Symbol & Variable & Units $^{\mathrm{a}}$ & Dependency \\
\hline Saother & Body surface area - other & centimeters $^{2}$ & \\
\hline Shieldsoil & Soil shielding factor & dimensionless & \\
\hline Shieldsed & Sediment shielding factor & dimensionless & \\
\hline Ml & Mass loading of soil in air & kilograms/meter ${ }^{3}$ & \\
\hline Afsoil & Adherence factor for soil & $\begin{array}{l}\text { milligrams/ } \\
\text { centimeter }^{2} / \text { day }\end{array}$ & \\
\hline Afsed & Adherence factor for sediment & $\begin{array}{l}\text { milligrams/ } \\
\text { centimeter } 2 / \text { day }\end{array}$ & \\
\hline Irsoilchild & Soil ingestion rate - child & kilograms/day & \\
\hline Irsoiladult & Soil ingestion rate - adult & kilograms/day & \\
\hline Irsedchild & Sediment ingestion rate - child & kilograms/day & \\
\hline Irsedadult & Sediment ingestion rate - adult & kilograms/day & \\
\hline Irriver & Ingestion rate for river water & kilograms/day & \\
\hline Irseep & Ingestion rate for seep water & kilograms/day & \\
\hline Irfish & Ingestion rate for fish & kilograms/day & \\
\hline Irleafy & Ingestion rate for leafy vegetables & kilograms/day & \\
\hline Irroot & Ingestion rate for root vegetables & kilograms/day & \\
\hline Irmeat & Ingestion rate for meat & kilograms/day & \\
\hline Irbird & Ingestion rate for birds & kilograms/day & \\
\hline Irgrate & Irrigation rate for crops & liters/meter ${ }^{2} /$ year & \\
\hline Dfsoil & Dose factor for soil - radionuclides & $\begin{array}{l}\text { rem/hour per pico } \\
\text { curie/kilogram }\end{array}$ & $\mathrm{C}$ \\
\hline Dfswim & Dose factor for swimming - radionuclides & $\begin{array}{l}\text { rem/hour per pico } \\
\text { curie/kilogram }\end{array}$ & $\mathrm{C}$ \\
\hline Dfboat & Dose factor for boating - radionuclides & $\begin{array}{l}\text { rem/hour per pico } \\
\text { curie/kilogram }\end{array}$ & $\mathrm{C}$ \\
\hline Dfing & Dose factor for ingestion - radionuclides & $\begin{array}{l}\text { rem/hour per pico } \\
\text { curie/kilogram }\end{array}$ & $\mathrm{C}$ \\
\hline Dfinh & Dose factor for inhalation - radionuclides & $\begin{array}{l}\text { rem/hour per pico } \\
\text { curie/kilogram }\end{array}$ & $\mathrm{C}$ \\
\hline Sfinh & Slope factor for inhalation - carcinogens & $\begin{array}{l}1 /(\text { milligrams/ kilogram } \\
\text { per day) }\end{array}$ & $\mathrm{C}$ \\
\hline Sfing & Slope factor for ingestion - carcinogens & $\begin{array}{l}1 /(\text { milligrams/ kilogram } \\
\text { per day) }\end{array}$ & $\mathrm{C}$ \\
\hline Hqinh & $\begin{array}{l}\text { Hazard quotient (reference dose) for inhalation - non- } \\
\text { carcinogen }\end{array}$ & $\begin{array}{l}\text { (milligrams/ kilogram } \\
\text { per day) }\end{array}$ & $\mathrm{C}$ \\
\hline
\end{tabular}


Table A.13. (contd)

\begin{tabular}{|l|l|l|l||}
\hline \multicolumn{1}{|c|}{ Symbol } & \multicolumn{1}{|c|}{ Variable } & \multicolumn{1}{c|}{ Units $^{\text {a }}$} & \multicolumn{1}{|c||}{ Dependency } \\
\hline \hline Hqing & $\begin{array}{l}\text { Hazard quotient (reference dose) for ingestion - non- } \\
\text { carcinogen }\end{array}$ & $\begin{array}{l}\text { (milligrams/ kilogram } \\
\text { per day) }\end{array}$ & C \\
\hline Kd & Distribution coefficient for surface soil & kilograms/liter & C \\
\hline Biofish & Bioaccumulation for fish & dimensionless & C \\
\hline Crveg & Vegetation concentration ratio & dimensionless & C \\
\hline Tfdeer & Transfer factor for deer & dimensionless & C \\
\hline Tfbird & Transfer factor for birds & dimensionless & C \\
\hline Vf & Volatilization factor & liters/meter ${ }^{3}$ & C \\
\hline Kp & Skin permeability coefficient & centimeters/hour \\
\hline Absorp & Skin absorption factor & dimensionless & C \\
\hline A Units shown are those for which input values are currently accepted by the legacy code but are not necessarily \\
C $\quad$ contaminant
\end{tabular}

Table A.14. Key Variables for Contaminant Impact on Ecological Species

\begin{tabular}{|l|l|l|l||}
\hline \multicolumn{1}{|c|}{ Symbol } & \multicolumn{1}{|c|}{ Variable } & \multicolumn{1}{c|}{ Units } & \multicolumn{1}{c|}{ Dependency } \\
\hline \hline bpore & Relative exposure time to pore water & Dimensionless & S \\
\hline Kps 1 & Plant-soil partition coefficient & $\begin{array}{l}\text { kilogram soil/kilogram plant } \\
\text { wet weight }\end{array}$ & S \\
\hline Kpa2 & Plant-air partition coefficient & meters /kilogram wet weight & S \\
\hline Bv & Bioconcentration factor for vegetation & Dimensionless & C \\
\hline Kow & Octanol-water partition coefficient & Dimensionless & C \\
\hline alphaij & Chemical assimilation efficiency in predator i for prey j & $\begin{array}{l}\text { grams contaminant } \\
\text { ingested } / \text { grams contaminant }\end{array}$ & C, S \\
\hline Bcf & Bioconcentration factor & liters/kilogram & C, S \\
\hline Kei & Contaminant specific depuration rate & liters/day & C, S \\
\hline Kmi & Metabolism loss rate & liters/day & C, S \\
\hline alphaing & Ingestion absorption factor & Dimensionless & C, S \\
\hline alphapar & Inhalation particle absorption factor & Dimensionless & C, S \\
\hline alphavap & Inhalation absorption factor for vapor & Dimensionless & C, S \\
\hline Kp & Dermal absorption from water & centimeters/hour & C, S \\
\hline \hline
\end{tabular}


Table A.14. (contd)

\begin{tabular}{|l|l|l|l||}
\hline \hline alphad & Dermal permeability constant for soil & Percentage & C, S \\
\hline $\mathrm{K}_{\mathrm{d}}$ & Soil-water partition coefficient & centimeter ${ }^{3} /$ gram & C, L \\
\hline $\mathrm{C} \quad=$ contaminant & & \\
$\mathrm{L} \quad=$ Location & & \\
$\mathrm{S} \quad=$ species & & \\
\hline
\end{tabular}

\section{Key Data for Each Waste Site}

The following tables provide material type, assumptions, and data information about classes of waste sites in the Hanford Site Disposition Baseline for the year 2004:

- 100 Areas waste site information shown in Table A.15

- 300, 400, and 600 areas waste site information shown in Table A.16

- Central Plateau waste site information shown in Table A.17.

Table A.15. Hanford Site Disposition Baseline in Year 2004 for the 100 Areas $^{3}$

\begin{tabular}{|c|c|c|}
\hline Material Type & $\begin{array}{c}\text { Hanford Site Disposition Baseline } \\
\text { Assumptions }\end{array}$ & $\begin{array}{c}\text { Data Needed for Simulation of Hanford Site } \\
\text { Disposition Baseline }\end{array}$ \\
\hline \multirow{4}{*}{$\begin{array}{l}\text { Irradiated Fuel } \\
\text { K Basin fuel and } \\
\text { associated sludge, } \\
\text { debris, water, and } \\
\text { equipment }\end{array}$} & $\begin{array}{l}\text { Spent Fuel - Final disposition at a } \\
\text { national repository }\end{array}$ & $\begin{array}{l}\text { Inventory, location, and date (Minimum } \\
\text { information needed is current inventory, location, } \\
\text { and date of export from the Hanford Site.) }\end{array}$ \\
\hline & $\begin{array}{l}\text { K Basin Sludge - Transuranic- } \\
\text { contaminated waste to be processed, } \\
\text { packaged, and sent to the Waste } \\
\text { Isolation Pilot Plant in Carlsbad, } \\
\text { New Mexico for final disposal }\end{array}$ & $\begin{array}{l}\text { Inventory, location, and date (Minimum } \\
\text { information needed is current inventory, location, } \\
\text { and date of export from the Hanford Site.) }\end{array}$ \\
\hline & $\begin{array}{l}\text { Contaminated Debris up to } 0.9 \\
\text { meter ( } 3 \text { feet) below grade or any } \\
\text { foundation - Excavated and } \\
\text { disposed in ERDF; excavation } \\
\text { backfilled with clean material }\end{array}$ & $\begin{array}{l}\text { Inventory, volume, location, and date of remedial } \\
\text { action (date sent to ERDF or begin and end dates } \\
\text { of continuous and linear remedial action) }\end{array}$ \\
\hline & $\begin{array}{l}\text { Clean Debris up to } 0.9 \text { meter } \\
\text { ( } 3 \text { feet) below grade or any } \\
\text { foundation - Excavated and used as } \\
\text { clean backfill; excavation backfilled } \\
\text { with clean material }\end{array}$ & $\begin{array}{l}\text { Definition of clean; assumed to be free of any } \\
\text { Hanford contamination }\end{array}$ \\
\hline
\end{tabular}

${ }^{3}$ Several of the remedies included in the Hanford Site Disposition Baseline do not reflect a final remedy selected by the regulatory agency. Those remedies not final will be the subject of future studies and records of decision. The baseline includes a logical remedial action based on records of decision and interim records of decision issued to date. 
Table A.15. (contd)

\begin{tabular}{|c|c|c|}
\hline Material Type & $\begin{array}{c}\text { Hanford Site Disposition Baseline } \\
\text { Assumptions }\end{array}$ & $\begin{array}{c}\text { Data Needed for Simulation of Hanford Site } \\
\text { Disposition Baseline }\end{array}$ \\
\hline & $\begin{array}{l}\text { Residual deeper than } 0.9 \text { meter } \\
\text { ( } 3 \text { feet) below grade or any } \\
\text { foundation - Fixed contamination } \\
\text { left in place and buried }\end{array}$ & $\begin{array}{l}\text { Inventory of residual } \\
\text { Time of remedial action } \\
\text { Location and form of residual } \\
\text { - } \quad \text { Fixed to concrete } \\
\text { - } \quad \text { Contaminated soil } \\
\text { Characteristics of cover if one applied }\end{array}$ \\
\hline & Groundwater Plumes & $\begin{array}{l}\text { Addressed under Environmental Contamination - } \\
\text { Groundwater }\end{array}$ \\
\hline & Contaminated Water & $\begin{array}{l}\text { Inventory, volume } \\
\text { Release model and supporting data }\end{array}$ \\
\hline \multirow[t]{2}{*}{ Irradiated Fuel (contd) } & Contaminated Equipment & $\begin{array}{l}\text { Inventory, volume } \\
\text { Release model and supporting data }\end{array}$ \\
\hline & $\begin{array}{l}\text { Waste Deriving from Processing } \\
\text { the Fuel and Sludge - Waste } \\
\text { generated? Yes or no. If yes, } \\
\text { provide the needed information. }\end{array}$ & $\begin{array}{l}\text { Estimates of waste inventory } \\
\text { Will it be disposed on site or off site? } \\
\text { If on site, what are the waste form and its } \\
\text { release characteristics? } \\
\text { When will it be produced and where will it be } \\
\text { disposed? }\end{array}$ \\
\hline \begin{tabular}{|l} 
Surplus Facilities \\
(Facility Transition and \\
Facility Decontamination \\
and Decommissioning) \\
Production Reactors (B, \\
C, D, DR, F, H, KE, \\
KW, and N, \\
including N Basins)
\end{tabular} & $\begin{array}{l}\text { Production Reactors - One piece } \\
\text { removal of eight production reactors } \\
\text { (C, D, DR, F, H, KE, KW, and N, } \\
\text { including N Basins) to a disposal } \\
\text { site in the northwest corner of the } \\
200 \text { West Area after } 75 \text { years (per } \\
\text { the SPRD EIS ROD) }\end{array}$ & $\begin{array}{l}\text { Inventory (for analysis of disposal in the } \\
200 \text { West Area); date of remedial action; location } \\
\text { of disposal in the } 200 \text { West Area }\end{array}$ \\
\hline $\begin{array}{l}\text { Other surplus facilities } \\
\text { and ancillary } \\
\text { equipment }\end{array}$ & \begin{tabular}{|l|} 
B Reactor - Remain in its present \\
location and developed as a National \\
Historic Site
\end{tabular} & $\begin{array}{l}\text { Inventory and location of waste are needed for } \\
\text { the analysis of long-term risk and impact at its } \\
\text { river shore location }\end{array}$ \\
\hline \multirow{2}{*}{$\begin{array}{l}\text { B Reactor is National } \\
\text { Historical Site and } \\
\text { N Reactor will have } \\
\text { its own plan }\end{array}$} & $\begin{array}{l}\text { Other Surplus Facilities and } \\
\text { Ancillary Equipment: }\end{array}$ & \\
\hline & $\begin{array}{l}\text { Contaminated Debris from } \\
\text { radioactive or mixed waste up to } \\
0.9 \text { meter ( } 3 \text { feet) below grade or } \\
\text { any foundation - Excavated and } \\
\text { disposed in ERDF; excavation } \\
\text { backfilled with clean material }\end{array}$ & $\begin{array}{l}\text { Inventory, location (for example, facility), date } \\
\text { of the remedial action. If completed over an } \\
\text { extended period of time, provide start date and } \\
\text { end date. }\end{array}$ \\
\hline
\end{tabular}


Table A.15. (contd)

\begin{tabular}{|c|c|c|}
\hline Material Type & $\begin{array}{c}\text { Hanford Site Disposition Baseline } \\
\text { Assumptions }\end{array}$ & $\begin{array}{c}\text { Data Needed for Simulation of Hanford Site } \\
\text { Disposition Baseline }\end{array}$ \\
\hline & $\begin{array}{l}\text { Purely Hazardous Waste (non- } \\
\text { radioactive) - Packaged, shipped, } \\
\text { and disposed off site }\end{array}$ & $\begin{array}{l}\text { Inventory, location, and date of the remedial } \\
\text { action (such as, date of shipment off site). }\end{array}$ \\
\hline $\begin{array}{l}\text { Surplus Facilities } \\
\text { (Facility Transition and } \\
\text { Facility Decontamination } \\
\text { and Decommissioning) }\end{array}$ & $\begin{array}{l}\text { Clean Debris up to } 0.9 \text { meter } \\
\text { ( } 3 \text { feet) below grade or any } \\
\text { foundations - Excavated and used } \\
\text { as clean backfill; excavation } \\
\text { backfilled with clean material } \\
\text { Note: Debris includes surplus } \\
\text { facilities, ancillary equipment, and } \\
\text { ancillary piping. }\end{array}$ & $\begin{array}{l}\text { Definition of clean, assumed to be free of any } \\
\text { Hanford contamination. }\end{array}$ \\
\hline \begin{tabular}{|l} 
Environmental \\
Contamination - \\
Groundwater \\
100 Area Plumes \\
(riverbank springs, \\
seepages, Columbia \\
River, and \\
groundwater)
\end{tabular} & $\begin{array}{l}\text { Contaminated Groundwater and } \\
\text { Vadose Zone and Aquifer } \\
\text { Sediment in Contact with } \\
\text { Groundwater - Simulate as a } \\
\text { no-action case }\end{array}$ & $\begin{array}{l}\text { Spatial distribution in three dimensions of the } \\
\text { concentration of potential contaminants of } \\
\text { concern (for example, concentration, spatial } \\
\text { location, porosity, and date). Initial condition or } \\
\text { history match information for simulation of } \\
\text { contaminant migration and fate. } \\
\text { (Minimum information needed is estimate of } \\
\text { plume mass today for history match; other } \\
\text { releases and the physics of migration will } \\
\text { determine the mass in the groundwater today.) }\end{array}$ \\
\hline $\begin{array}{l}\text { Environmental } \\
\text { Contamination - Soil } \\
\text { Sites } \\
\text { Liquid Disposal Sites - } \\
\text { Cribs (tritium, } \\
\text { strontium-90, } \\
\text { cesium-137, } \\
\text { carbon-14, nitrates, } \\
\text { and sulfates) } \\
\text { Liquid Disposal Sites } \\
\text { (cribs, ponds, } \\
\text { ditches, and other) } \\
\end{array}$ & $\begin{array}{l}100 \text { Area Soil Sites - Residential } \\
\text { scenario used to establish cleanup } \\
\text { levels for the Records of Decision. } \\
\text { Excavate to } 4.5 \text { meters ( } 15 \text { feet) } \\
\text { below the structure. Note: } \\
\text { Structures range from grade to } \\
4.5 \text { meters below grade; therefore, } \\
\text { some excavations approach the } \\
\text { groundwater level. }\end{array}$ & $\begin{array}{l}\text { Inventory, location, and date of the remedial } \\
\text { action. If completed during an extended period } \\
\text { of time, provide start and end dates. } \\
\text { Inventory excavated and disposed in ERDF } \\
\text { Estimate of any transuranic-contaminated } \\
\text { material inventory that would be packaged } \\
\text { and exported to the Waste Isolation Pilot } \\
\text { Plant in Carlsbad, New Mexico } \\
\text { Residual inventory not remediated and its } \\
\text { composition and distribution in the } \\
\text { subsurface }\end{array}$ \\
\hline $\begin{array}{l}\text { Miscellaneous } \\
\text { Underground Storage } \\
\text { Tanks }\end{array}$ & $\begin{array}{l}100 \text { Area Miscellaneous } \\
\text { Underground Storage Tanks - } \\
\text { Residential scenario used to } \\
\text { establish cleanup levels for the } \\
\text { Records of Decision. This means to } \\
\text { excavate or pull, crush, and dispose } \\
\text { in ERDF. }\end{array}$ & $\begin{array}{l}\text { Same as for above "Environmental } \\
\text { Contamination - Soil Sites" }\end{array}$ \\
\hline
\end{tabular}


Table A.15. (contd)

\begin{tabular}{|c|c|c|}
\hline Material Type & $\begin{array}{c}\text { Hanford Site Disposition Baseline } \\
\text { Assumptions }\end{array}$ & $\begin{array}{c}\text { Data Needed for Simulation of Hanford Site } \\
\text { Disposition Baseline }\end{array}$ \\
\hline $\begin{array}{l}\text { Solid Waste } \\
\text { Pre-1970 unsegregated } \\
\text { transuranic- } \\
\text { contaminated buried } \\
\text { waste; suspect } \\
\text { transuranic- } \\
\text { contaminated waste } \\
\text { and inactive waste } \\
\text { sites }\end{array}$ & $\begin{array}{l}100 \text { Area Solid Waste Burial } \\
\text { Grounds - Residential scenario } \\
\text { used to establish cleanup levels for } \\
\text { the Records of Decision; excavate } \\
\text { the solid waste and dispose in ERDF }\end{array}$ & $\begin{array}{l}\text { Inventory, location, and date of the remedial } \\
\text { action. If completed over an extended period of } \\
\text { time, provide start and end dates. } \\
\text { Inventory excavated and disposed in ERDF } \\
\text { Estimate of any transuranic-contaminated } \\
\text { material inventory that would be packaged } \\
\text { and exported to Waste Isolation Pilot Plant } \\
\text { in Carlsbad, New Mexico } \\
\text { Residual inventory not remediated and its } \\
\text { composition and distribution in the } \\
\text { subsurface }\end{array}$ \\
\hline $\begin{array}{l}\text { Newly Generated Solid } \\
\text { Waste (onsite } \\
\text { generated) }\end{array}$ & $\begin{array}{l}\text { Newly Generated Solid Waste - } \\
\text { All disposed in } 200 \text { Areas solid } \\
\text { waste burial grounds }\end{array}$ & $\begin{array}{l}\text { Inventory estimate of waste to be generated; } \\
\text { location of disposal (such as, operational area } \\
\text { (200 East or } 200 \text { West, and trench or aggregated } \\
\text { release area); see Solid Waste Information } \\
\text { Forecast Tracking for dates volumes, and } \\
\text { inventory of waste generation and disposal }\end{array}$ \\
\hline \multirow[t]{2}{*}{ DOE Land Control } & $\begin{array}{l}\text { Until closure and during the } 100- \\
\text { year period of institutional control. }\end{array}$ & $\begin{array}{l}\text { The land remains under DOE control, and the } \\
\text { land use is as described in the Records of } \\
\text { Decision from DOE (DOE/ROD- 6450-01-P). }\end{array}$ \\
\hline & $\begin{array}{l}\text { After the period of institutional } \\
\text { control }\end{array}$ & $\begin{array}{l}\text { Land use following institutional control } \\
\text { addressed initially by Central Plateau Risk } \\
\text { Framework }\end{array}$ \\
\hline $\begin{array}{ll}\text { DOE } & \text { U.S. Departme } \\
\text { ERDF } & \text { Environmental }\end{array}$ & of Energy & \\
\hline
\end{tabular}


Table A.16. Hanford Site Disposition Baseline in Year 2004 for the 300, 400, and 600 Areas $^{(a)}$

\begin{tabular}{|c|c|c|}
\hline Material Type & $\begin{array}{c}\text { Hanford Site Disposition Baseline } \\
\text { Assumptions }\end{array}$ & $\begin{array}{l}\text { Data Needed for Simulation of } \\
\text { Hanford Site Disposition Baseline }\end{array}$ \\
\hline \begin{tabular}{|l} 
Irradiated Fuel \\
Examples for \\
300/400 Areas: \\
Fast Flux Test Facility fuel \\
Sodium-bonded \\
Experimental Breeder \\
Reactor-II fuel \\
Test Reactor and Isotope \\
Production General \\
Atomics (TRIGA) \\
(308 Building) \\
Light water reactor \\
(generally high to \\
moderately irradiated \\
fuel)
\end{tabular} & $\begin{array}{l}\text { Spent Fuel - All weapons production and } \\
\text { non-weapons production spent fuel } \\
\text { exported from the Hanford Site for final } \\
\text { disposal } \\
\text { Additional Processing - No further } \\
\text { processing of spent nuclear fuel necessary } \\
\text { after interim storage and prior to disposal }\end{array}$ & $\begin{array}{l}\text { Inventory, location (current location } \\
\text { and future onsite location), and date of } \\
\text { movement, especially date of export } \\
\text { from the Hanford Site } \\
\text { Fast Flux Test Facility fuel } \\
\text { Sodium-bonded Experimental } \\
\text { Breeder Reactor-II fuel } \\
\text { TRIGA fuel } \\
\text { Light water reactor fuel } \\
\text { (Minimum information needed is } \\
\text { current inventory, location, and date of } \\
\text { export from the Hanford Site.) }\end{array}$ \\
\hline $\begin{array}{l}\text { Special Nuclear Materials } \\
\text { Inventory } \\
\text { Non self-protecting special } \\
\text { nuclear materials and } \\
\text { nuclear materials and } \\
\text { unirradiated uranium } \\
\text { Green Fast Flux Test } \\
\text { Facility fuel }\end{array}$ & $\begin{array}{l}2500 \text { Low Enriched Uranium Billets, } \\
\text { such as over } 700,000 \text { kilograms } \\
\text { (1.6 million pounds) of normal and low } \\
\text { enriched uranium - Transitioned to be of } \\
\text { beneficial use in the United Kingdom } \\
\text { Unirradiated Fast Flux Test Facility } \\
\text { Fuel - Transferred from the } 308 \text { Building } \\
\text { to the Plutonium Finishing Plant in the } \\
200 \text { West Area for secure interim storage } \\
\text { before export from the Hanford Site }\end{array}$ & $\begin{array}{l}\text { Inventory, location (current location } \\
\text { and future onsite location), and date of } \\
\text { movement, especially date of export } \\
\text { from Hanford. } \\
\text { (Minimum information needed is } \\
\text { current inventory, location, and date of } \\
\text { export from the Hanford Site.) }\end{array}$ \\
\hline $\begin{array}{l}\text { Strontium-90/Cesium-137 } \\
\text { Capsules } \\
\text { Small number of } \\
\text { strontium-90/ } \\
\text { cesium-137 capsules } \\
\text { Isotopic heat sources } \\
\text { stored in the } \\
\text { 324 Building, as } \\
\text { returned from the } \\
\text { Federal Republic of } \\
\text { Germany }\end{array}$ & $\begin{array}{l}\text { Strontium-90/Cesium-137 Capsules - } \\
\text { Transferred to the Central Plateau for } \\
\text { interim storage before final disposition } \\
\text { decision and disposal off site }\end{array}$ & $\begin{array}{l}\text { Inventory, location (current location } \\
\text { and future onsite location), and date of } \\
\text { movement, especially date of export } \\
\text { from the Hanford Site } \\
\text { (Minimum information needed is } \\
\text { current inventory, location, and date of } \\
\text { export from the Hanford Site.) }\end{array}$ \\
\hline
\end{tabular}


Table A.16. (contd)

\begin{tabular}{|c|c|c|}
\hline Material Type & $\begin{array}{c}\text { Hanford Site Disposition Baseline } \\
\text { Assumptions }\end{array}$ & $\begin{array}{l}\text { Data Needed for Simulation of } \\
\text { Hanford Site Disposition Baseline }\end{array}$ \\
\hline \begin{tabular}{|l|} 
Surplus Facilities \\
(Facility Transition and \\
Facility Decontamination and \\
Decommissioning) \\
Reactor (Fast Flux Test \\
Facility) \\
Fuel Materials Examination \\
Facility \\
324/325/327 Buildings \\
Other Existing 309, 306, \\
308, etc., Facilities \\
\end{tabular} & $\begin{array}{l}\text { Surplus Facilities and Ancillary } \\
\text { Equipment } \\
\text { Contaminated Debris from radioactive } \\
\text { or mixed waste up to } 0.9 \text { meter ( } 3 \text { feet) } \\
\text { below grade or any foundation - } \\
\text { Excavated and disposed in ERDF; } \\
\text { excavation is backfilled with clean } \\
\text { material }\end{array}$ & $\begin{array}{l}\text { Inventory, location (for example, } \\
\text { facility), date of the remedial action. If } \\
\text { completed during an extended period of } \\
\text { time, provide start date and end date. }\end{array}$ \\
\hline \begin{tabular}{|l|} 
Surplus Facilities \\
Miscellaneous underground \\
storage tanks (associated \\
with facilities) \\
\end{tabular} & $\begin{array}{l}\text { Purely Hazardous Waste (non- } \\
\text { radioactive) - Packaged, shipped, and } \\
\text { disposed off site }\end{array}$ & $\begin{array}{l}\text { Inventory, location, and date of the } \\
\text { remedial action, especially the date of } \\
\text { shipment off site }\end{array}$ \\
\hline $\begin{array}{l}\text { Advanced reactors facilities } \\
\text { are the Plutonium } \\
\text { Recycle Test } \\
\text { Reactor/309 Building } \\
\text { and Nuclear Energy } \\
\text { Legacy facilities, such as } \\
\text { non-nuclear used in } \\
\text { Liquid-Metal Fast } \\
\text { Breeder Reactor } \\
\text { program (for example, } \\
\text { processing and analytical } \\
\text { laboratories, High } \\
\text { Temperature Sodium } \\
\text { Facility, etc. and the Fast } \\
\text { Flux Test Facility/Fuel } \\
\text { Materials Examination } \\
\text { Facility) }\end{array}$ & $\begin{array}{l}\text { Clean Debris up to } 0.9 \text { meters ( } 3 \text { feet) } \\
\text { below grade or any foundation - } \\
\text { Excavated and used as clean backfill; } \\
\text { excavation is backfilled with clean } \\
\text { material } \\
\text { (Note: Debris includes surplus facilities, } \\
\text { ancillary equipment, and ancillary piping.) }\end{array}$ & $\begin{array}{l}\text { Definition of clean, assumed to be free } \\
\text { of Hanford contamination. }\end{array}$ \\
\hline $\begin{array}{l}\text { Energy Northwest } \\
\text { Washington Nuclear } \\
\text { Plant } 2\end{array}$ & $\begin{array}{l}\text { All radioactive waste from Energy } \\
\text { Northwest will be disposed in the } \\
\text { Commercial Low-Level Waste Disposal } \\
\text { Facility operated by US Ecology, Inc. }\end{array}$ & $\begin{array}{l}\text { Definition of residual contamination, } \\
\text { assumed to be free of radioactive } \\
\text { contamination in the baseline. }\end{array}$ \\
\hline
\end{tabular}


Table A.16. (contd)

\begin{tabular}{|c|c|c|}
\hline Material Type & $\begin{array}{c}\text { Hanford Site Disposition Baseline } \\
\text { Assumptions }\end{array}$ & $\begin{array}{l}\text { Data Needed for Simulation of } \\
\text { Hanford Site Disposition Baseline }\end{array}$ \\
\hline $\begin{array}{l}\text { Environmental } \\
\text { Contamination - } \\
\text { Groundwater } \\
300 \text { Area plumes } \\
600 \text { Area plumes }\end{array}$ & $\begin{array}{l}\text { Contaminated Groundwater and } \\
\text { Vadose Zone and Aquifer Sediment in } \\
\text { Contact with Groundwater - Simulate } \\
\text { as a no-action case }\end{array}$ & $\begin{array}{l}\text { Spatial distribution in three dimensions } \\
\text { of the concentration of potential } \\
\text { contaminants of concern (for example, } \\
\text { concentration, spatial location, porosity, } \\
\text { and date); initial condition for } \\
\text { simulation of future migration and fate } \\
\text { (Minimum information needed is } \\
\text { estimate of plume mass today for } \\
\text { history match; other releases and the } \\
\text { physics of migration will determine the } \\
\text { mass in the groundwater today.) }\end{array}$ \\
\hline $\begin{array}{l}\text { Environmental } \\
\text { Contamination - Soil Sites } \\
\text { Liquid disposal sites - } \\
\text { cribs, ponds, and ditches } \\
\text { Liquid disposal sites - } \\
\text { miscellaneous } \\
\text { underground storage } \\
\text { tanks }\end{array}$ & $\begin{array}{l}300 \text { Area Soil Sites - Clean up to } \\
\text { industrial standards per Records of } \\
\text { Decision; excavate to } 4.5 \text { meters ( } 15 \text { feet) } \\
\text { below the structure. Note: Structures } \\
\text { range from grade to } 4.5 \text { meters below } \\
\text { grade; therefore, some excavations } \\
\text { approach the groundwater level. }\end{array}$ & $\begin{array}{l}\text { Inventory, location, and date of the } \\
\text { remedial action. If completed during an } \\
\text { extended period of time provide start } \\
\text { date and end date. } \\
\text { Inventory excavated and disposed in } \\
\text { ERDF } \\
\text { Estimate of any transuranic waste- } \\
\text { contaminated material inventory } \\
\text { that would require packaging and } \\
\text { shipment to Waste Isolation Plant } \\
\text { in Carlsbad, New Mexico } \\
\text { Residual inventory not remediated, its } \\
\text { composition, and distribution in the } \\
\text { subsurface }\end{array}$ \\
\hline $\begin{array}{l}\text { Solid Waste } \\
\text { Pre-1970 unsegregated } \\
\text { transuranic } \\
\text { contaminated buried } \\
\text { waste }\end{array}$ & $\begin{array}{l}300 \text { Area Solid Waste Burial Grounds - } \\
\text { Clean up to industrial standards per } \\
\text { Records of Decision; excavate the solid } \\
\text { waste and dispose in ERDF }\end{array}$ & $\begin{array}{l}\text { Inventory, location, and date of the } \\
\text { remedial action. If completed over an } \\
\text { extended period of time, provide start } \\
\text { date and end date. Assume all remedial } \\
\text { action waste is disposed in ERDF. } \\
\text { (Applies to all solid waste burial } \\
\text { grounds) }\end{array}$ \\
\hline $\begin{array}{l}\text { Retrievably Stored Solid } \\
\text { Waste - transuranic } \\
\text { alpha: caissons } 618-10 \\
\text { and } 618-11 \text { burial } \\
\text { ground }\end{array}$ & $\begin{array}{l}\text { 618-10 and 618-11 Suspected TRU- } \\
\text { Contaminated Waste - The TRU } \\
\text { component is to be stabilized, packaged, } \\
\text { interim stored in the Central Plateau, and } \\
\text { then disposed off site }\end{array}$ & $\begin{array}{l}\text { Inventory, location, and date of } \\
\text { remedial action for } 618-10 \text { and } 618-11 \\
\text { burial ground caissons. The inventory } \\
\text { will include the fraction of waste from } \\
\text { caissons disposed as low-level waste, } \\
\text { fraction packaged and disposed off site } \\
\text { as transuranic waste at the Waste } \\
\text { Isolation Plant in Carlsbad, New } \\
\text { Mexico, and fraction remaining as } \\
\text { residual contamination }\end{array}$ \\
\hline
\end{tabular}


Table A.16. (contd)

\begin{tabular}{|c|c|c|}
\hline Material Type & $\begin{array}{c}\text { Hanford Site Disposition Baseline } \\
\text { Assumptions }\end{array}$ & $\begin{array}{c}\text { Data Needed for Simulation of } \\
\text { Hanford Site Disposition Baseline }\end{array}$ \\
\hline $\begin{array}{l}\text { Retrievably stored liquid } \\
\text { waste mixed, Toxic } \\
\text { Substance Control Act } \\
\text { (hexone, etc.) }\end{array}$ & $\begin{array}{l}\text { Toxic Substance Control Act Waste - } \\
\text { Stored pending an approved treatment. } \\
\text { Residues disposed on site. }\end{array}$ & $\begin{array}{l}\text { Original inventory, location, and date. } \\
\text { Present day residual inventory, if any, } \\
\text { location, and date. }\end{array}$ \\
\hline $\begin{array}{l}\text { Radioactive sodium at Fast } \\
\text { Flux Test Facility and } \\
\text { legacy waste }\end{array}$ & $\begin{array}{l}\text { Radioactive Sodium and Legacy Waste } \\
\text { - Stabilized and disposed on site }\end{array}$ & Inventory, location, and date of transfer \\
\hline $\begin{array}{l}\text { Newly Generated Solid } \\
\text { Waste (non-radioactive, } \\
\text { demolition waste) }\end{array}$ & $\begin{array}{l}\text { Inert Demolition Waste - Disposed in } \\
\text { Non-Radioactive and Dangerous Waste } \\
\text { Landfill }\end{array}$ & $\begin{array}{l}\text { Inventory, location, and date (only if it } \\
\text { includes non-hazardous chemical of } \\
\text { interest) }\end{array}$ \\
\hline \multirow[t]{2}{*}{$\begin{array}{l}\text { Newly Generated } \\
\text { Radioactive Solid Waste } \\
\text { (transuranic and non- } \\
\text { transuranic) }\end{array}$} & $\begin{array}{l}\text { Newly Generated Non-Transuranic } \\
\text { Radioactive Waste - Disposed in the } \\
\text { Central Plateau solid waste burial grounds }\end{array}$ & $\begin{array}{l}\text { Inventory, location (for example, trench } \\
\text { number), and date of disposal in the } 200 \\
\text { Area solid waste burial grounds }\end{array}$ \\
\hline & $\begin{array}{l}\text { Newly Generated Transuranic } \\
\text { Radioactive Waste - Processed, } \\
\text { packaged, and interim stored at the Central } \\
\text { Plateau pending transport to the Waste } \\
\text { Isolation Plant in Carlsbad, New Mexico } \\
\text { for final disposal }\end{array}$ & $\begin{array}{l}\text { Inventory, source location at the } \\
\text { Hanford Site, and date of export to the } \\
\text { Waste Isolation Plant in Carlsbad, New } \\
\text { Mexico }\end{array}$ \\
\hline \multicolumn{3}{|c|}{$\begin{array}{l}\text { TRIGA = Test Reactor and Isotope Production General Atomics } \\
\text { (a) Several of the remedies included in the Hanford Site Disposition Baseline do not reflect a final remedy selected by the } \\
\text { regulatory agency. Those remedies not final will be the subject of future studies and records of decision. The baseline } \\
\text { includes a logical remedial action based on records of decision and interim records of decision issued to date. }\end{array}$} \\
\hline
\end{tabular}


Table A.17. Hanford Site Disposition Baseline in Year 2003 for the Central Plateau ${ }^{(a)}$

\begin{tabular}{|c|c|c|}
\hline Material Type & $\begin{array}{c}\text { Hanford Site Disposition Baseline } \\
\text { Assumptions }\end{array}$ & $\begin{array}{c}\text { Data Needed for Simulation of } \\
\text { Hanford Site Disposition Baseline }\end{array}$ \\
\hline $\begin{array}{l}\text { Irradiated Fuel } \\
\text { Examples are } \\
\text { K-Basin fuel stabilized in a multi- } \\
\text { canister overpack in the Canister } \\
\text { Storage Building } \\
\text { Spent nuclear fuel stored in burial } \\
\text { ground } \\
\text { Spent nuclear fuel in T Plant, etc. } \\
\text { Covers Shippingport fuel, TRIGA } \\
\text { fuel including that in low-level waste } \\
\text { burial grounds, Fast Flux Test Facility } \\
\text { fuel, and miscellaneous fuel materials }\end{array}$ & $\begin{array}{l}\text { Spent Fuel - All weapons production } \\
\text { and non-weapons production spent fuel } \\
\text { will have final disposition at a National } \\
\text { Repository } \\
\text { Additional Processing - No further } \\
\text { processing of spent nuclear fuel is } \\
\text { necessary after interim storage and prior } \\
\text { to disposal }\end{array}$ & $\begin{array}{l}\text { Inventory (for mass balance) } \\
\text { - } \quad \text { K Basin fuel } \\
\text { TRIGA, light water reactor, and } \\
\text { Fast Flux Test Facility fuels in the } \\
400 \text { Area and interim stored in the } \\
200 \text { Areas interim storage area } \\
\text { - Shippingport fuels in T Plant } \\
\text { removed to } 200 \text { Areas interim } \\
\text { storage area } \\
\text { Sodium-bonded Fast Flux Test } \\
\text { Facility spent nuclear fuel } \\
\text { transferred offsite to Idaho } \\
\text { National Engineering and } \\
\text { Environmental Laboratory in } \\
\text { Idaho Falls, Idaho for disposition } \\
\text { Minimum information needed for the } \\
\text { 2004 Composite Analysis is current } \\
\text { inventory, location, and date of export } \\
\text { from the Hanford Site }\end{array}$ \\
\hline $\begin{array}{l}\text { Special Nuclear Material and } \\
\text { Nuclear Material Inventory } \\
\text { Plutonium Finishing Plant } \\
\text { Materials -solutions, metal, } \\
\quad \text { polycubes } \\
\text { Existing oxides } \\
\text { Hold up material } \\
\text { Non self-protecting nuclear materials } \\
\text { (for example, fuel grade plutonium } \\
\text { oxide, green Fast Flux Test Facility } \\
\text { fuel elements, etc. and other (weapons } \\
\text { usable fissile material)) } \\
\text { Unirradiated uranium }\end{array}$ & $\begin{array}{l}\text { Special Nuclear Material and Nuclear } \\
\text { Material - All special nuclear material } \\
\text { and nuclear material inventory removed } \\
\text { from the Hanford Site and stored in a } \\
\text { location to be determined }\end{array}$ & $\begin{array}{l}\text { Inventory (for mass balance) } \\
\text { - } \quad \text { Plutonium Finishing Plant } \\
\text { - Materials, for example, } \\
\text { solutions, metal, polycubes } \\
\text { - Existing oxides } \\
\text { - Hold up material } \\
\text { - Non self-protecting nuclear } \\
\text { materials (for example, fuel grade } \\
\text { plutonium oxide, green Fast Flux } \\
\text { Test Facility fuel elements, etc, } \\
\text { and other (weapons usable fissile } \\
\text { material)) } \\
\text { Unirradiated uranium } \\
\text { Minimum information needed for the } \\
\text { 2004 Composite Analysis is current } \\
\text { inventory, location, and date of export } \\
\text { from the Hanford Site. }\end{array}$ \\
\hline $\begin{array}{l}\text { Strontium-90/Cesium-137 Capsules } \\
\text { Storage in Waste Encapsulation and } \\
\text { Storage Facility }\end{array}$ & $\begin{array}{l}\text { Strontium-90/Cesium-137 Capsules - } \\
\text { Strontium and cesium capsules, declared } \\
\text { to be waste, transported to a National } \\
\text { Repository for final disposal }\end{array}$ & $\begin{array}{l}\text { Inventory (for mass balance) } \\
\text { Minimum information needed for the } \\
2004 \text { Composite Analysis is current } \\
\text { inventory, location, and date of export } \\
\text { from the Hanford Site. }\end{array}$ \\
\hline
\end{tabular}


Table A.17. (contd)

\begin{tabular}{|c|c|c|}
\hline Material Type & $\begin{array}{c}\text { Hanford Site Disposition Baseline } \\
\text { Assumptions }\end{array}$ & $\begin{array}{c}\text { Data Needed for Simulation of } \\
\text { Hanford Site Disposition Baseline }\end{array}$ \\
\hline \multicolumn{3}{|c|}{ Double-Shell Tank/Single-Shell Tank Systems } \\
\hline Single-shell tank waste & $\begin{array}{l}\text { Single-Shell Tank Retrieval - } \\
\text { System capable of meeting the Tri- } \\
\text { Party Agreement } 99 \% \text { waste volume } \\
\text { removal milestone } \\
\text { Double-Shell Tank and } \\
\text { Miscellaneous Underground } \\
\text { Storage Tanks Retrieval - } \\
\text { comparable to the } 99 \% \text { waste volume } \\
\text { removal }\end{array}$ & $\begin{array}{l}\text { Inventory of the waste removed } \\
\text { from the single- and double-shell } \\
\text { tanks } \\
\text { Sequence and dates of single-shell } \\
\text { tank, double-shell tank, } \\
\text { miscellaneous underground storage } \\
\text { tank waste retrieval } \\
\text { Inventory of the waste residual in } \\
\text { single- and double-shell tanks }\end{array}$ \\
\hline $\begin{array}{l}\text { Immobilized low-activity } \\
\text { waste - a tank waste stream; } \\
\text { includes multiple waste forms } \\
\text { where applicable. } \\
\text { Immobilized high-level waste - } \\
\text { a tank waste stream. } \\
\text { Secondary waste streams from } \\
\text { WTP }\end{array}$ & $\begin{array}{l}\text { High-Level Fraction - Interim } \\
\text { stored until shipped off site to the } \\
\text { National Repository } \\
\text { Low-Activity Fraction - } \\
\text { Immobilized and disposed onsite in a } \\
200 \text { Area disposal ground designed } \\
\text { for the immobilized low-activity } \\
\text { waste } \\
\text { Retrieval, Separation, and } \\
\text { Vitrification Operation Waste } \\
\text { Streams - Disposed in solid waste } \\
\text { burial grounds managed by DOE in } \\
\text { the } 200 \text { East Area }\end{array}$ & $\begin{array}{l}\text { Inventory split to high-level waste } \\
\text { stream (for mass balance) } \\
\text { Inventory split and release models } \\
\text { for immobilized low-activity waste } \\
\text { stream disposed of in existing grout } \\
\text { vaults and new disposal facility; } \\
\text { dates and rates of immobilized low- } \\
\text { activity waste disposal; includes the } \\
\text { splits among alternate waste forms; } \\
\text { includes anticipated residuals in the } \\
\text { WTP itself for facility closure. } \\
\text { Disposal location, inventory } \\
\text { estimates and release models for } \\
\text { waste generated during the retrieval, } \\
\text { separation, and vitrification } \\
\text { operations (for example, waste } \\
\text { ranging from contaminated clothing } \\
\text { and tools to failed equipment such } \\
\text { as pumps and melters); dates of } \\
\text { waste generation and disposal; } \\
\text { includes release models for alternate } \\
\text { waste forms. }\end{array}$ \\
\hline
\end{tabular}


Table A.17. (contd)

\begin{tabular}{|c|c|c|}
\hline Material Type & $\begin{array}{c}\text { Hanford Site Disposition Baseline } \\
\text { Assumptions }\end{array}$ & $\begin{array}{c}\text { Data Needed for Simulation of } \\
\text { Hanford Site Disposition Baseline }\end{array}$ \\
\hline \multicolumn{3}{|c|}{ Double-Shell Tank/Single-Shell Tank Systems (contd) } \\
\hline \multirow[t]{2}{*}{$\begin{array}{l}\text { Single-shell tanks, double-shell } \\
\text { tanks, miscellaneous under- } \\
\text { ground storage tanks, ancillary } \\
\text { storage tanks }\end{array}$} & $\begin{array}{l}\text { Tank Closure - All single-shell } \\
\text { tanks, double-shell tanks, } \\
\text { miscellaneous underground storage } \\
\text { tanks, and ancillary storage tanks } \\
\text { stabilized to prevent subsidence and } \\
\text { closed in place } \\
\text { All in-tank equipment, structures, } \\
\text { and underlying and adjacent } \\
\text { contaminated soil disposed in place }\end{array}$ & $\begin{array}{l}\text { Inventory of the waste residual } \\
\text { Waste form, release models, and } \\
\text { release model data for the residual } \\
\text { in the stabilized tank. } \\
\text { Inventory associated with in-tank } \\
\text { equipment and structures } \\
\text { Waste form, release models, and } \\
\text { release model data for in-tank } \\
\text { equipment and structures }\end{array}$ \\
\hline & $\begin{array}{l}\text { Surface Barrier - All tanks closed } \\
\text { with a surface barrier consistent with } \\
\text { their contents. }\end{array}$ & $\begin{array}{l}\text { Infiltration rate through the surface } \\
\text { and periods of time representing } \\
\text { pre-Hanford, the Hanford } \\
\text { operational period, interim barriers, } \\
\text { final barrier, barrier degradation, } \\
\text { long-term post barrier design life } \\
\text { Geochemical mobility of } \\
\text { contaminants in subsurface soil and } \\
\text { sediment }\end{array}$ \\
\hline \multicolumn{3}{|c|}{ Surplus Facilities (Facility Transition and Decommissioning and Decontamination) } \\
\hline $\begin{array}{l}\text { Existing Chemical Separations } \\
\text { Plants - (B Plant, T Plant, } \\
\text { U Plant PUREX, REDOX) }\end{array}$ & $\begin{array}{l}\text { Separations Plants - B Plant, } \\
\text { T Plant, U Plant, PUREX, REDOX } \\
\text { brought down to their cover block } \\
\text { grade, stabilized, and covered with a } \\
\text { surface protective barrier (entombed } \\
\text { in place) }\end{array}$ & $\begin{array}{l}\text { Inventory in the debris removed } \\
\text { from the surplus facilities and } \\
\text { disposed in ERDF, and its waste } \\
\text { form (for example, contaminated } \\
\text { concrete, contaminated metal); dates } \\
\text { of remedial actions } \\
\text { Inventory in the Chemical } \\
\text { Separations buildings at and below } \\
\text { the cover blocks, and the waste } \\
\text { forms, release models, and release } \\
\text { model parameters }\end{array}$ \\
\hline PUREX Tunnels & $\begin{array}{l}\text { PUREX Tunnels - Stabilized to } \\
\text { prevent subsidence and covered with } \\
\text { a protective surface barrier }\end{array}$ & $\begin{array}{l}\text { Inventory, waste form, release } \\
\text { models, and release model } \\
\text { parameters for in-place disposal of } \\
\text { PUREX tunnels; dates of remedial } \\
\text { action }\end{array}$ \\
\hline
\end{tabular}


Table A.17. (contd)

\begin{tabular}{|c|c|c|}
\hline Material Type & $\begin{array}{c}\text { Hanford Site Disposition Baseline } \\
\text { Assumptions } \\
\end{array}$ & $\begin{array}{c}\text { Data Needed for Simulation of } \\
\text { Hanford Site Disposition Baseline }\end{array}$ \\
\hline \multicolumn{3}{|l|}{ Surplus Facilities (contd) } \\
\hline Other Existing Facilities & $\begin{array}{l}\text { Plutonium Finishing Plant } \\
\text { Production Area - Decontaminated, } \\
\text { stabilized to prevent subsidence, and } \\
\text { covered with a surface barrier }\end{array}$ & $\begin{array}{l}\text { Inventory, waste form, release } \\
\text { models, and release model } \\
\text { parameters for Plutonium Finishing } \\
\text { Plant decontamination and } \\
\text { decommissioning; dates of remedial } \\
\text { action }\end{array}$ \\
\hline $\begin{array}{l}\text { Miscellaneous Underground } \\
\text { Storage Tanks }\end{array}$ & $\begin{array}{l}\text { Miscellaneous underground } \\
\text { storage tanks_- If ever contained } \\
\text { high-level waste, treated the same as } \\
\text { single-shell tanks } \\
\text { Miscellaneous underground } \\
\text { storage tanks - If never contained } \\
\text { high-level waste, stabilized to } \\
\text { prevent subsidence and covered with } \\
\text { a protective surface barrier }\end{array}$ & $\begin{array}{l}\text { (see notes above on single-shell } \\
\text { tank/double-shell tank waste } \\
\text { removal and remedial action) } \\
\text { Inventory (chemical and/or low- } \\
\text { level waste), waste form, release } \\
\text { models, and release model } \\
\text { parameters; dates of remedial } \\
\text { action; performance of the } \\
\text { protective surface barrier to be } \\
\text { specified }\end{array}$ \\
\hline $\begin{array}{l}\text { New Facilities (for example, } \\
\text { Cold Vacuum Drying Facility, } \\
\text { Canister Storage Building, } \\
\text { Waste Receiving and } \\
\text { Processing, etc.) }\end{array}$ & $\begin{array}{l}\text { New Facilities, Other Existing } \\
\text { Facilities - Those without an } \\
\text { identified post-closure mission } \\
\text { decontaminated and decommissioned } \\
\text { with debris going to ERDF }\end{array}$ & $\begin{array}{l}\text { Inventory, waste form, release } \\
\text { models, and release model } \\
\text { parameters for ERDF disposal; } \\
\text { dates of decontamination and } \\
\text { decommissioning actions; the time } \\
\text { of construction and performance of } \\
\text { protective surface barriers, and their } \\
\text { degradation processes and degraded } \\
\text { performance }\end{array}$ \\
\hline ERDF & $\begin{array}{l}\text { ERDF - recipient of all CERCLA } \\
\text { waste generated during cleanup by } \\
\text { the Environmental Restoration } \\
\text { Contractor closed with a protective } \\
\text { surface cover }\end{array}$ & $\begin{array}{l}\text { Inventory, release models, and } \\
\text { release model parameters for the } \\
\text { waste disposed in each cell; date of } \\
\text { placement and performance } \\
\text { estimates for the protective surface } \\
\text { barrier; long-term performance } \\
\text { estimates of the installed double } \\
\text { liner. }\end{array}$ \\
\hline
\end{tabular}


Table A.17. (contd)

\begin{tabular}{|c|c|c|}
\hline Material Type & $\begin{array}{c}\text { Hanford Site Disposition Baseline } \\
\text { Assumptions } \\
\end{array}$ & $\begin{array}{c}\text { Data Needed for Simulation of } \\
\text { Hanford Site Disposition Baseline }\end{array}$ \\
\hline \multicolumn{3}{|c|}{ Environmental Contamination - Groundwater } \\
\hline 200-Area plumes & $\begin{array}{l}\text { Groundwater-Simulate pump and } \\
\text { treat actions to date for the Central } \\
\text { Plateau. } \\
\text { Groundwater - Assume reinjection } \\
\text { of treated fluid at the cleanup } \\
\text { standard. }\end{array}$ & $\begin{array}{l}\text { Either (a) spatial distribution (areal } \\
\text { extent and depth) and concentration } \\
\text { of potential contaminants of } \\
\text { concern; initial condition for } \\
\text { simulation of future migration and } \\
\text { fate, or (b) pump and treat, and } \\
\text { reinjection data } \\
\text { Inventory of contaminant removal; } \\
\text { dates of remedial action, and } \\
\text { especially the end date of the pump } \\
\text { and treat remedial action. } \\
\text { Minimum information needed for } \\
\text { planned analysis is estimate of } \\
\text { plume mass today for history match; } \\
\text { other releases and the physics of } \\
\text { migration will determine the mass in } \\
\text { the groundwater today. }\end{array}$ \\
\hline
\end{tabular}


Table A.17. (contd)

\begin{tabular}{|c|c|c|}
\hline Material Type & $\begin{array}{c}\text { Hanford Site Disposition Baseline } \\
\text { Assumptions } \\
\end{array}$ & $\begin{array}{c}\text { Data Needed for Simulation of } \\
\text { Hanford Site Disposition Baseline }\end{array}$ \\
\hline \multicolumn{3}{|c|}{ Environmental Contamination - Soil Sites } \\
\hline $\begin{array}{l}\text { Liquid Disposal Sites - Cribs, } \\
\text { ponds, ditches and other } \\
\text { including unplanned releases } \\
\text { Miscellaneous underground } \\
\text { storage tanks not single-shell } \\
\text { tank or double-shell tank } \\
\text { related }\end{array}$ & $\begin{array}{l}\text { Soil Sites Outside the Central } \\
\text { Plateau-Clean up to standards. } \\
\text { Excavate to } 4.5 \text { meters ( } 15 \text { feet) } \\
\text { below the structure. Note: Structures } \\
\text { range from grade to } 4.5 \text { meters below } \\
\text { grade. } \\
\text { Soil Sites Inside the Central Plateau- } \\
\text { Stabilized and covered with a } \\
\text { protective barrier - use the planned } \\
\text { remedial actions of the } 200 \text { Area Soil } \\
\text { Sites project as the baseline } \\
\text { Miscellaneous Underground Storage } \\
\text { Tanks - Stabilized in place and } \\
\text { covered with a protective barrier }\end{array}$ & $\begin{array}{l}\text { Inventory excavated and disposed in } \\
\text { ERDF; dates of remedial actions } \\
\text { Inventory of residual and its form } \\
\text { following cleanup of past practice } \\
\text { liquid discharge sites } \\
\text { Estimate of any excavated } \\
\text { transuranic contaminated materials } \\
\text { that would be packaged and } \\
\text { exported to the Waste Isolation Pilot } \\
\text { Plant in Carlsbad, New Mexico } \\
\text { Waste form model and supporting } \\
\text { data to support release modeling for } \\
\text { each waste form; e.g., soil-debris, } \\
\text { cement } \\
\text { For surface barriers, provide the } \\
\text { infiltration rate through the surface } \\
\text { and periods of time representing } \\
\text { pre-Hanford, the Hanford } \\
\text { operational period, interim barriers, } \\
\text { final barrier, barrier degradation, } \\
\text { long-term post barrier design life }\end{array}$ \\
\hline \multicolumn{3}{|l|}{ Solid Waste } \\
\hline $\begin{array}{l}\text { Pre-1970 un-segregated } \\
\text { transuranic buried waste from } \\
200,100 \text { and } 300 \text { areas }\end{array}$ & $\begin{array}{l}\text { Pre-1970 Transuranic } \\
\text { Contaminated Buried Waste - } \\
\text { Stabilized and covered with a } \\
\text { protective barrier }\end{array}$ & $\begin{array}{l}\text { Inventory and waste form to support } \\
\text { release modeling; dates of barrier } \\
\text { construction and barrier } \\
\text { performance }\end{array}$ \\
\hline $\begin{array}{l}\text { Retrievably stored transuranic } \\
\text { solid waste including Z-9 } \\
\text { trench soil }\end{array}$ & $\begin{array}{l}\text { Retrievably Stored Transuranic } \\
\text { Solid Waste - Retrieved and } \\
\text { transported to the Waste Isolation } \\
\text { Pilot Plant in Carlsbad, New Mexico } \\
\text { for final disposal }\end{array}$ & $\begin{array}{l}\text { Inventory (for mass balance) and } \\
\text { date of off-site disposal }\end{array}$ \\
\hline
\end{tabular}


Table A.17. (contd)

\begin{tabular}{|c|c|c|}
\hline Material Type & $\begin{array}{c}\text { Hanford Site Disposition Baseline } \\
\text { Assumptions }\end{array}$ & \begin{tabular}{|c|} 
Data Needed for Simulation of \\
Hanford Site Disposition Baseline
\end{tabular} \\
\hline \multicolumn{3}{|l|}{ Solid Waste (contd) } \\
\hline $\begin{array}{l}\text { Alpha caissons } 200 \text { West } \\
\text { transuranic storage and the one } \\
\text { near 222S Lab }\end{array}$ & $\begin{array}{l}\text { Alpha caissons - To be decided; } \\
\text { assume TRU storage waste is } \\
\text { repackaged and shipped to the Waste } \\
\text { Isolation Pilot Plant. }\end{array}$ & $\begin{array}{l}\text { To be decided; assume TRU storage } \\
\text { waste is repackaged and shipped to } \\
\text { the Waste Isolation Pilot Plant. } \\
\text { Inventory for mass balance and date } \\
\text { of off-site disposal }\end{array}$ \\
\hline $\begin{array}{l}\text { Post-1970 segregated non- } \\
\text { transuranic buried waste }\end{array}$ & $\begin{array}{l}\text { Post-1970 Segregated Non-TRU } \\
\text { Buried Waste - Stabilized and } \\
\text { disposed in place with a protective } \\
\text { surface barrier }\end{array}$ & $\begin{array}{l}\text { Inventory and waste form for } \\
\text { release modeling; date of barrier } \\
\text { construction and barrier } \\
\text { performance }\end{array}$ \\
\hline $\begin{array}{l}\text { Retrievably stored non- } \\
\text { transuranic solid waste }\end{array}$ & $\begin{array}{l}\text { Retrievably Stored Non- } \\
\text { Transuranic Solid Waste_- To be } \\
\text { decided; assume to be stabilized and } \\
\text { disposed in low-level burial grounds } \\
\text { with protective surface barriers }\end{array}$ & $\begin{array}{l}\text { Inventory and waste form for } \\
\text { release modeling; date of barrier } \\
\text { construction and barrier } \\
\text { performance }\end{array}$ \\
\hline $\begin{array}{l}\text { Grout Site - Post } 1970 \text { low- } \\
\text { level waste }\end{array}$ & $\begin{array}{l}\text { Grout Site - Post-1970 Low-Level } \\
\text { Solid Waste - Disposed in place } \\
\text { without a protective barrier }\end{array}$ & $\begin{array}{l}\text { Inventory of the grout waste form, } \\
\text { and release model parameters for } \\
\text { the grout waste form release model } \\
\text { of the phosphate/sulfate waste }\end{array}$ \\
\hline $\begin{array}{l}\text { Newly Generated Solid Waste } \\
\text { - On site generated and off site } \\
\text { receipts of non-ERDF, } \\
\text { meaning non-CERCLA waste. }\end{array}$ & $\begin{array}{l}\text { Newly Generated Solid Waste - If } \\
\text { low-level radioactive waste, then } \\
\text { disposed in the active Central Plateau } \\
\text { solid waste burial grounds. If non- } \\
\text { radioactive waste, then disposed in } \\
\text { the Central Landfill. Disposal in } \\
\text { place after stabilized to prevent } \\
\text { subsidence and a protective surface } \\
\text { barrier constructed }\end{array}$ & $\begin{array}{l}\text { Inventory of the solid waste burial } \\
\text { grounds, waste form, release } \\
\text { models, and release model } \\
\text { parameters (for example, soil- } \\
\text { debris, high integrity containers, } \\
\text { naval reactor compartments); date } \\
\text { of engineered barrier construction } \\
\text { and barrier performance pre- } \\
\text { Hanford, during operations, interim } \\
\text { cover, final cover, degraded cover, } \\
\text { and post cover design life. }\end{array}$ \\
\hline $\begin{array}{l}\text { Newly Generated Solid Waste } \\
\text { - On site generated receipts } \\
\text { from Environmental } \\
\text { Restoration Program - ERDF }\end{array}$ & $\begin{array}{l}\text { ERDF - Disposal in place with a } \\
\text { protective surface barrier }\end{array}$ & $\begin{array}{l}\text { Inventory of newly generated solid } \\
\text { waste, waste form, release models, } \\
\text { and release model parameters; dates } \\
\text { of barrier construction over cells; } \\
\text { performance of double-liner and } \\
\text { sump system }\end{array}$ \\
\hline
\end{tabular}


Table A.17. (contd)

\begin{tabular}{|c|c|c|}
\hline Material Type & $\begin{array}{c}\text { Hanford Site Disposition Baseline } \\
\text { Assumptions }\end{array}$ & $\begin{array}{c}\text { Data Needed for Simulation of } \\
\text { Hanford Site Disposition Baseline }\end{array}$ \\
\hline \multicolumn{3}{|l|}{ Solid Waste (contd) } \\
\hline $\begin{array}{l}\text { Newly Generated Solid Waste - } \\
\text { U.S. } \\
\text { Ecology Inc. operation of the } \\
\text { commercial low-level waste } \\
\text { disposal facility }\end{array}$ & $\begin{array}{l}\text { Commercial Low-Level Waste } \\
\text { Disposal Facility - Stabilized and } \\
\text { covered with a protective surface } \\
\text { barrier as in closure plan (as } \\
\text { amended and accepted by the State of } \\
\text { Washington, Department of Health) }\end{array}$ & $\begin{array}{l}\text { Inventory of the commercial low- } \\
\text { level waste site, waste form and } \\
\text { release models, stabilization efforts } \\
\text { (assume no subsidence), protective } \\
\text { barrier design; dates of trench } \\
\text { closure and barrier construction; } \\
\text { assumed performance of all } \\
\text { engineered barriers }\end{array}$ \\
\hline \multicolumn{3}{|c|}{$\begin{array}{l}\text { (a) Several of the remedies included in the Hanford Site Disposition Baseline do not reflect a final remedy selected by the } \\
\text { regulatory agency. Those remedies not final will be the subject of future studies and records of decision. The baseline } \\
\text { includes a logical remedial action based on records of decision and interim records of decision issued to date. }\end{array}$} \\
\hline
\end{tabular}

The Composite Analysis activity relies on many programs at the Hanford Site to provide information needed for the assessment. Among the most important of these are the assessment programs supporting the tank farms, the solid waste burial grounds, and the immobilized low-activity waste disposal facilities and ERDF. In addition, two inventory models are being applied at the Hanford Site: the Hanford Soil Inventory Model (SIM) for crib discharges and selected unplanned releases, and the Hanford Tank Waste Operation Simulator (HTWOS) model for the movement of tank waste and its transformation into final waste forms at final disposal locations. Both of these models are fundamental to assembling an overall or holistic inventory database for Hanford waste sites. These models also rely on estimates of the radionuclides generated at the Hanford Site in production reactors based on the revised Oak Ridge Isotope Generation and Depletion Code (ORIGEN2) simulations (ORNL-5621) and the Best Basis Inventory of tank waste (HNF-SD-WM-SP-012).

The System Assessment Capability (SAC) is being modified to enable import into the SAC deterministic analysis of 1) release to vadose zone or 2) release to water table for select sites calculated by other assessment programs. The Composite Analysis Team will interpret "best estimate" simulations by other programs to be "median" simulations and incorporate them into an overall "median-input" deterministic simulation.

To perform a stochastic analysis, the outside program's best-estimate data (geologic profile, hydraulic properties, geochemical properties, recharge sequence, etc.) will be interpreted as "median" values for distributions where the data range is defined by the Hanford wide data set previously compiled for SAC. A highly simplified model, (such as, release and one-dimensional vadose zone or release and twodimensional vadose zone) will be calibrated or conditioned to reproduce the median simulation provided by the outside program. This simplified but calibrated model will be used to generate the stochastic realizations. Where available, comparison will be made between the range of SAC stochastic responses and the range of deterministic sensitivity cases provided by the program. 
Significant differences may exist between the SAC representation of uncertainty and the representation of sensitivity used by other assessments. This is especially true when the site-specific assessment is using sensitivity analyses to explore alternate conceptual models of waste form release (for example, tank residuals modeled with a solubility model, diffusion model, advection-desorption model, linear release time--model) or barrier performance (for example, alternate surface barriers and engineered containment systems surrounding a glass waste form). The immobilized low-activity waste (ILAW) performance assessment (DOE/ORP-2000-24) is a case where a broad spectrum of sensitivity cases was used to explore alternate conceptual models as well as extremes of model parameters.

In addition, the future waste forms and their disposal for the low-activity tank waste fraction have not been finalized. Accordingly, the alternatives to vitrified glass waste form will be evaluated using sensitivity cases once supplemental waste forms are selected.

\section{Step 4: Specify Boundaries of Analysis}

The primary objective of DQO Step 4 is to identify the population of interest, define the spatial and temporal boundaries that apply to each decision statement, define the scale of decision making, and identify any practical constraints (hindrances or obstacles) that must be taken into consideration in the sampling design. Implementing this step ensures the 2004 Composite Analysis will be based on data that accurately reflect the cumulative impact from the Hanford Site to future members of the public.

\section{Population of Interest}

The analysis of the maximum exposure and dose to a member of the public from a median or central tendency analysis applies to the land area where future members of the public may be exposed to radionuclides that have migrated from final disposal locations at the Hanford Site. This area will exclude a waste management area assumed to remain under Federal government control and not be accessible to the public. The decisions will be based on calculated doses for the first 1000 years after Hanford Site closure. However, calculation of doses will be carried out for longer periods of time to fully understand the potential migration and long-term fate of the radionuclides. No accident or intruder scenarios will be considered. The population within the region is assumed to remain constant over time.

\section{Spatial Boundaries}

Geographic boundaries of the 2004 Composite Analysis for the surface and subsurface water pathways extend across the Hanford Site from Rattlesnake Mountain to the Columbia River and include the Columbia River from Vernita Bridge to the City of Richland. Where the boundary of the Hanford Site coincides with the Columbia River, the boundary is the high water mark of the river. Future Hanford Site boundaries are expected to retract to the Core Zone where facilities are expected to remain for some time to manage the remaining waste at the Hanford Site. It is also anticipated that groundwater in this area will be precluded from use. The initial assessment performed with SAC used McNary Dam as its lower boundary. This analysis and the Solid Waste Environmental Impact Statement (DOE/EIS-0286D2) have shown that in the future the concentration of contaminants downstream of Richland are estimated to be 
less than at Richland. This analysis will therefore use the City of Richland as its lower boundary, and resolution of the river model may be refined to improve the contaminant concentration estimates along the Hanford Reach.

Geographic boundaries of the 2004 Composite Analysis for the air pathway are a northern boundary that runs west to east through the Saddle Mountains and the community of Othello. The southern boundary passes just south of the community of Umatilla and McNary Dam. The eastern boundary runs northsouth through the community of Wallula near the confluence of the Columbia and Walla Walla rivers. The western boundary runs north-south just west of the community of Grandview and Priest Rapids Dam. Within the spatial boundaries of the assessment it is necessary to clearly define the population of disposal waste sites (locations of contaminant sources) that apply to each decision statement defined in Section 2. Rigorous definition of the receptor locations is not required because the long-term analyses place receptors at all possible points of exposure and seek to determine the maximum impact or dose regardless of location.

The Waste Information Data System (WIDS) database showed 2730 waste sites at the Hanford Site in January 2003. An additional 46 sites were identified and included as either future disposal sites, (e.g., the Integrated Disposal Facility), or collector sites for future off-site shipments, (e.g., TRU waste going to WIPP, HLW going to Yucca Mountain, or SNM to be shipped to other sites in the DOE complex). Of these 2776 sites, 1046 were identified for consideration in the 2004 Composite Analysis. Several screens were applied to the WIDS list of waste sites to identify those to be included in the 2004 Composite Analysis. Waste sites were screened out that were 1) initially misclassified as waste sites (for example, ones that have been relabeled and are no longer classified as waste sites), 2) not representing releases to the environment, 3) receiving waste streams categorized as "non" radioactive or "non" hazardous chemical waste streams, 4) not including key waste types, and 5) duplicate sites.

The bulk of the 1046 waste sites are located within the 100, 200, and 300 areas. However, some waste was discharged or disposed outside of these operational areas (for example, the Gable Mountain Pond, waste disposal caissons at 618-11 located adjacent to the Energy Northwest property, 300 North burial grounds, and Environmental Restoration Disposal Facility [ERDF] located between 200 West and 200 East areas). The Hanford Site also includes a commercial low-level waste disposal site operated by US Ecology Inc. that is located southwest of the 200 East Area.

Table A.18 summarizes the screening process of going from 2730 sites in WIDS to 1046 waste sites considered in the 2004 Composite Analysis, which involved a number of screening rules. The table includes a description of the data source or screen applied, the number of sites added or deleted, and the number of sites retained after application of the screen. The original number of WIDS sites is supplemented by 46 sites not named in WIDS but needed to represent non-DOE waste and future waste disposals or accumulations of waste (for example, the commercial low-level radioactive waste disposal facility operated by US Ecology Inc., a stack release point for the future Waste Treatment Plant complex, future offsite shipments).

The series of screens that eliminate sites begins with the elimination of WIDS sites originally classified as either "rejected" or "rejected proposed." "Rejected proposed" is the label placed on a waste site in the 
WIDS database that is proposed for rejection. In addition, sites without an inventory that are reclassified as "closed out," "deleted from NPL (National Priorities List)," "interim closed out," "no action," "rejected," or "rejected consolidated" are eliminated.

Sites are also dropped based on their waste site type not being an environmental release point (for example, septic tanks, fabrication shops, offices, control structures, loading docks, storage pads ( $<90$ day), burn pits, coal ash pits, sanitary sewers). If releases occurred from such waste sites, they are addressed under "unplanned releases." "Storage pads ( $<90$ day)" is terminology used in WIDS to indicate a storage pad for Resource Conservation and Recovery Act (RCRA) identified waste that can be stored at a generator site for no longer than 90 days.

Sites representing "non" radioactive or "non" hazardous chemical waste streams are also omitted from the 2004 Composite Analysis. Similarly, waste sites found to contain only hazardous non-radioactive waste are omitted on the basis of the waste type (for example., waste sites devoted to ash, asbestos, demolition and inert waste, ordinance, storm water runoff).

A number of duplicate site names, a crib constructed but never used, several consolidated unplanned releases, and several new unplanned releases involving minor surface contamination are all eliminated from consideration. Finally, through a review of WIDS records for specific waste sites, a determination has been made that some specific sites are negligible (for example, removed and disposed tumble weeds and small surface spills that have been remediated). When applying a screen, candidates for elimination are always compared to a list of "waste sites with inventory data" and retained in the 2004 Composite Analysis if listed.

The list of waste sites included in the 2004 Composite Analysis may change. The WIDS file from January 2003 will be used throughout. However, the Hanford SIM simulator or the HTWOS simulator may identify more or different sites. Future work to define inventories may indicate that sites on the list of 1046 may not be particularly relevant environmental releases. At this time, June 2004, data are being assembled for a total of 1046 waste sites that are under consideration for inclusion in the 2004 Composite Analysis. 
Table A.18. Summary of Screening Rules Applied to Identify Waste Sites for the 2004 Composite Analysis

\begin{tabular}{|c|c|c|}
\hline Description of Data Source or Screen Applied & $\begin{array}{c}\text { Sites added }(+) \text {, } \\
\text { deleted }(-), \text { or } \\
\text { retained }\end{array}$ & $\begin{array}{l}\text { Sites after } \\
\text { Screen }\end{array}$ \\
\hline WIDS sites identified in January 2003 download & +2730 & 2730 \\
\hline Non-WIDS sites ${ }^{(a)}$ including future waste from HTWOS & +46 & 2776 \\
\hline $\begin{array}{l}\text { Waste sites classified as "rejected" or "proposed } \\
\text { rejected" plus no inventory, and those reclassified as } \\
\text { "closed out," "deleted from NPL" (National Priorities } \\
\text { List), "interim closed out," "no action," "rejected," or } \\
\text { "rejected (consolidation)" plus no inventory. }\end{array}$ & -888 & 1888 \\
\hline $\begin{array}{l}\text { Site types not representing environmental releases of } \\
\text { contaminants of interest }\end{array}$ & -575 & 1313 \\
\hline $\begin{array}{l}\text { Eliminate waste streams categorized as "non-dangerous" } \\
\text { or non-regulated, }\end{array}$ & -62 & 1251 \\
\hline Eliminate waste types & -80 & 1171 \\
\hline Eliminate duplicates ${ }^{(b)}$ & -8 & 1163 \\
\hline Eliminate test crib $^{(\mathrm{c})}$ & -1 & 1162 \\
\hline Eliminate consolidated unplanned releases ${ }^{(\mathrm{d})}$ & -8 & 1154 \\
\hline $\begin{array}{l}\text { Eliminate new unplanned releases with only } \\
\text { miscellaneous surface contamination }\end{array}$ & -9 & 1145 \\
\hline $\begin{array}{l}\text { Screened, negligible by Site Description }{ }^{(\mathrm{f})} \text { or previously } \\
\text { identified as negligible }\end{array}$ & -99 & 1046 \\
\hline \multicolumn{3}{|c|}{$\begin{array}{l}{ }^{a} \text { Non-WIDS sites: US Ecology, 221-B, 221-T, 224-U, 231-Z, 234-5Z, 218-E-LLW, 218-E- } \\
\text { RCRA, 218-E-Cores, 291-WTP, and 36 HTWOS waste streams }\end{array}$} \\
\hline \multicolumn{3}{|c|}{$\begin{array}{l}{ }^{\mathrm{b}} \text { Duplicates: UPR-200-E-103, UPR-200-E-41, UPR-200-W-11, UPR-200-W-27, UPR-200-W- } \\
\text { 36, UPR-200-W-62, UPR-200-W-164, and 200-E-106 (duplicate of ILAW disposal site) }\end{array}$} \\
\hline \multicolumn{3}{|l|}{${ }^{\mathrm{c}}$ Test crib: $600-262$} \\
\hline \multicolumn{3}{|c|}{$\begin{array}{l}{ }^{\mathrm{d}} \text { Consolidated unplanned releases: :200-E-120, 200-E-131, 200-E-132, 200-E-133, 200-W-93, } \\
\text { 200-W-94, 200-W-95, 200-W-96 }\end{array}$} \\
\hline \multicolumn{3}{|c|}{$\begin{array}{l}{ }^{\mathrm{e}} \text { New unplanned releases: UPR-200-E-100, UPR-200-E-101, UPR-200-E-91, UPR-200-E-97, } \\
\text { UPR-200-W-165, 200-E-53, 200-W-63, 300-256, 200-W-81 }\end{array}$} \\
\hline \multicolumn{3}{|l|}{${ }^{\mathrm{f}}$ Based on analysis of WIDS memo fields } \\
\hline \multicolumn{3}{|c|}{ g Eslinger (2001), MSExcel file "Unplanned_Disposition_Eslinger_circa January 2001.xls" } \\
\hline
\end{tabular}




\section{Temporal Boundaries}

The time period of the regulatory assessment shall be from 1944 through 3035 inclusive and includes 1000 years following the assumed Hanford Site closure date of 2035. Some analyses appearing in the 2004 CA will extend to 10,000 years post closure to identify peak releases that may occur after the 1000 -year regulatory period. A 1000 -year period of analysis is consistent with the 1000 -year period of regulatory compliance noted in DOE Order 435.1 for low-level radioactive waste. The 2004 Composite Analysis will account for releases to the environment from 1944 to the present to ensure temporal realism and be based on times of first detection and monitored mass in the groundwater aquifer. During the period from present day until site closure, the temporal resolution of releases will be the same to ensure a realistic representation of disposal and facility decontamination and decommissioning. Thereafter, the temporal resolution will be sufficient to support the risk and impact assessment. If necessary, use of annual average or coarser values of time from a groundwater or river simulation will be supplemented with empirical data to estimate seasonal variations in water quality.

DOE guidance for the composite analysis (DOE Order 435.1, DOE M435.1-1, DOE 1999) requires the analysis present results for a time period of at least 1000 years. The guidance also notes that analyses beyond 1000 years may be appropriate in the sensitivity/uncertainty analyses. This analysis has considered a regulatory time period of 1091 years beginning in 1944 and including the 1000 years following site closure. Sensitivity cases will be executed over a longer time period, up to 10,000 years after closure to more fully understand peak impact, the role of sorbed contaminants, and releases from engineered waste forms and disposal facilities after the 1,000 yrs after site closure.

Hanford Site programs have a variety of closure dates. DOE has moved to accelerate cleanup of the Hanford Site from 2070 to 2035 and possibly as soon as 2025 (DOE/RL-2002-47). The closure date for solid waste burial operations at the Hanford Site is 2046 (DOE/EIS-0286D2). However, the graphite cores of the production reactors are to undergo safe storage for fewer than 75 years and disposal in the 200 West Area of the Central Plateau (58 FR 48509). The US Ecology Inc. lease for the commercial lowlevel radioactive waste site expires on September 9, 2063, and Washington State has proposed 2056 for disposal operations to cease and closure preparations begin (WDOH-WDOE 2000). Each of these actions will be taken into account in the 2004 Composite Analysis as currently scheduled.

In the context of a long-term analysis, the precise closure date should not be significant because in a 1000-year period a 10-30 year difference in site closure date should not significantly influence peak concentrations, risk, or impact predicted to occur over a 1000-year regulatory period. For the purpose of presenting and discussing results, a Hanford Site closure date of 2035 will be adopted. Hence, the 100 -year institutional control period will extend from 2035 until 2135. The 1000-year post-closure regulatory period will be from 2035 until 3035, and a 10,000-year post-closure period of interest will close in 12,035. A few isolated disposal or remedial actions are scheduled beyond 2035. Those extended dates will be reflected in the 2004 Composite Analysis. 


\section{Other Conditions and Constraints}

The conditions and constraints on the 2004 Composite Analysis will be

- The risk components of the SAC will provide the basis for the cumulative effective dose equivalent to future, offsite members of the public.

- The 2004 Composite Analysis will focus on key radioactive disposal sites for which adequate information is available for analysis. WIDS circa January 2003 has been used to define an initial list of the sites of interest for this study. Selection of additional sites will be based on information from other programs as made available.

- The 2004 Composite Analysis will not include any sampling plans or sampling but will use field and laboratory data from other studies to ensure consistent and efficient use of resources.

- Because of project resource limits, the stochastic component of the 2004 Composite Analysis will be limited to 100 or fewer realizations, which will limit the uncertainty analysis to central tendency type studies.

- A major assumption in this assessment is that the current regional and local climate remains unchanged for the period of analysis.

- The analysis of background and non-Hanford contributions to contamination and risk will be limited to the Columbia River because of the significant regional watershed contributing background and non-Hanford contaminants to the Hanford Reach of the Columbia River.

\section{References}

40 CFR 141.66. 2000. "National Primary Drinking Water Regulations: Radionuclides, Final Rule." U.S. Code of Federal Regulations. Available on the Internet at http://www.epa.gov/safewater/mcl.html\#mcls.

40 CFR 192. "Health and Environmental Protection Standards for Uranium and Thorium Mill Tailings."

58 FR 48509. September 16, 1993. "Department of Energy, Record of Decision: Decommissioning of Eight Surplus Production Reactors at the Hanford Site, Richland, WA.” Federal Register.

Bechtel. 1999. Groundwater/Vadose Zone Integration Project: Preliminary System Assessment Capability Concepts for Architecture, Platform and Data Management. Bechtel Hanford Inc., Richland, Washington. Available on the Internet at http://www.hanford.gov/cp/gpp/modeling/sacarchive.cfm.

BHI-01673 Rev 0. 2003. 100-B/C Area Ecological Risk Assessment Data Quality Objectives. PG Doctor, KA Gano, RG Bauer, JK Linville, and TM Poston, Bechtel Hanford Inc., Richland, Washington.

DOE/EIS-0286D2. 2003. Revised Draft Hanford Site Solid (Radioactive and Hazardous) Waste Program Environmental Impact Statement, Richland, Washington. U.S. Department of Energy, Richland, Washington. 
DOE G435.1-1. 1999. Implementation Guide for Use with DOE M 435.1-1. U.S. Department of Energy Headquarters, Washington, D.C.

DOE M435.1-1. 1999. Radioactive Waste Management Manual. U.S. Department of Energy Headquarters, Washington, D.C. Available on the Internet at http://www.directives.doe.gov/pdfs/doe/doetext/neword/435/m4351-1c1.html

DOE Order 435.1. 1999. Radioactive Waste Management. U.S. Department of Energy Headquarters, Washington, D.C. Available on the Internet at http:/www.hanford.gov/wastemgt/doe/psg/pdf/doeo435.1.pdf.

DOE/ORP-2000-24 Rev 0 (Formerly DOE/RL/97-69). 2001. Hanford Immobilized Low-Activity Waste Performance Assessment: 2001 Version. U.S. Department of Energy Office of River Protection, Richland Washington.

DOE/RL-93-99 Rev 1. 1994. Remedial Investigation and Feasibility Study Report for the Environmental Restoration Disposal Facility. U.S. Department of Energy Richland Operations Office, Richland, Washington.

DOE/RL-2002-47. 2002. Performance Management Plan for the Accelerated Cleanup of the Hanford Site. Predecisional Draft B, U.S. Department of Energy Richland Operations Office, Richland, Washington.

DOE/RL-2002-59. 2003. Hanford Site Groundwater Strategy: Protection, Monitoring, and Remediation. U.S. Department of Energy Richland Operations Office, Richland, Washington.

DOE/RL-2003-08 Rev 0. May 2003. 100-B/C Area Ecological Risk Assessment Sampling and Analysis Plan. U.S. Department of Energy Richland Operations Office, Richland, Washington.

Eisenbud, M. 1987. Environmental Activity from Natural, Industrial, and Military Sources. Academic Press, Orlando, Florida.

EPA/540-R-00-007. 2000. "Soil Screening Guidance for Radionuclides: User's Guide." Table D.2, U.S. Environmental Protection Agency, Washington, D.C. Available on the Internet at http://www.epa.gov/oerrpage/superfund/resources/radiation/att_d-clean.pdf.

EPA-570/9-76-003. 1976. National Interim Primary Drinking Water Regulations. U.S. Environmental Protection Agency, Washington, D.C.

EPA/600/R-96/055. 2000. Guidance for the Data Quality Objective Process, EPA QA/G-4. U.S. Environmental Protection Agency, Washington, D.C. Available on the Internet at http://www.hanford.gov/dqo/keyelements.html. 
EPA OSWER Directive 9283.1-14. 2001. Use of Uranium Drinking Water Standards under 40 CFR 141 and 40 CFR 192 as Remediation Goals for Groundwater at CERCLA sites. Available on the Internet at http://www.epa.gov/superfund/resources/radiation/pdf/9283 1_14.pdf.

Eslinger, PW. 2001. "Unplanned Release Sites for SAC Rev. 0.” E-mail message from Paul W. Eslinger (Pacific Northwest National Laboratory, System Assessment Capability Software Development Lead) to Bob W. Bryce et al. (Pacific Northwest National Laboratory, System Assessment Capability Project Manager), January 25, 2001, Richland, Washington.

HNF-SD-WM-SP-012 Rev 4. 2002. Tank Farm Contractor Operation and Utilization Plan. RA Kirkbride, GK Allen, BA Higley, TM Hohl, SL Lambert, RM Orme, DE Place, JA Seidl, RS Wittman, JH Baldwin, JN Strode, JA Reddick, and LM Swanson, CH2M HILL Hanford Inc., Richland, Washington.

ORNL-5621. 1980. ORIGEN2 - A Revised and Updated Version of the Oak Ridge Isotope Generation and Depletion Code. AG Croft, Oak Ridge National Laboratory, Oak Ridge, Tennessee.

PNNL-11800. 1998. Composite Analysis for Low-Level Waste Disposal in the 200-Area Plateau of the Hanford Site. CT Kincaid, MP Bergeron, CR Cole, MD Freshley, NL Hassig, VG Johnson, DI Kaplan, RJ Serne, GP Streile, DL Strenge, PD Thorne, LW Vail, GA Whyatt, and SK Wurstner, Pacific Northwest National Laboratory, Richland, Washington.

PNNL-13910. 2002. Hanford Site Environmental Report for Calendar Year 2001. TM Poston, RW Hanf, RL Dirkes, and LF Morasch (eds.), Pacific Northwest National Laboratory, Richland, Washington. Available on the Internet at http://hanford-site.pnl.gov/envreport/2001/.

PNNL-14187. 2003. Hanford Groundwater Monitoring for Fiscal Year 2002. MJ Hartman, LF Morasch, and WD Webber (eds.), Pacific Northwest National Laboratory, Richland, Washington.

RCRA - Resource Conservation and Recovery Act. 1976. Public Law 94-580, as amended, 90 Stat. 2795, 42 USC 6901 et seq.

RPP-7884 Rev 0. 2002. Field Investigation Report for Waste Management Area S-SX; Volume 1, Main Text and Appendices A - C; Volume 2, Appendices D - I. AJ Knepp, CH2M HILL Hanford Group Inc., Richland, Washington.

RPP-10098 Rev 0. 2002. Field Investigation Report for Waste Management Area B-BX-BY; Volume 1, Main Text and Appendices A - C; Volume 2, Appendices D - I. AJ Knepp, Jacobs Engineering Group Inc., Richland, Washington.

WDOH-WDOE - Washington Department of Health and Washington Department of Ecology. 2000. Draft Environmental Impact Statement for the Commercial Low-Level Radioactive Waste Disposal Site, Richland, Washington. Washington State Departments of Health and Ecology, Olympia, Washington. 
WHC-EP-0645. 1995. Performance Assessment for the Disposal of Low-Level Waste in the 200 West Area Burial Grounds. MI Wood, R Khaleel, PD Rittmann, AH Liu, SH Finfrock, RJ Serne, and KJ Cantrell, Westinghouse Hanford Company, Richland, Washington.

WHC-SD-WM-TI-730 Rev 0. 1996. Performance Assessment for the Disposal of Low-Level Waste in the 200-East Area Burial Grounds. MI Wood, R Khaleel, PD Rittmann, SH Finfrock, TH DeLorenzo, and DY Garbrick, Westinghouse Hanford Company, Richland, Washington. 


\section{Distribution}

No. of

Copies

\section{OFFSITE}

2 Confederated Tribes of the Umatilla Indian Reservation

Environmental Planning

P.O. Box 638

Pendleton, OR 97801

ATTN: S. Harris J. H. Richards

2 Confederated Tribes and Bands of the Yakama Nation 1216 W. Kennewick Avenue

Kennewick, WA 99336

ATTN: R. Jim

R. Riggsbee

R. A. Danielson

Washington State Department of Health 5508 Englewood Avenue

Yakima, WA 98908

B. W. Drost

U.S. Geological Survey

1201 Pacific Avenue, Suite 600

Tacoma, WA 98402

D. Houston

Oregon Department of Energy

625 Marion Street, NE, Suite 1

Salem, OR 97301

R. E. Jacquish

1232 Vintage Avenue

Richland, WA 99352

G. L. Robertson

Washington State Department of Health

Division of Radiation Protection

P.O. Box 47827

Olympia, WA 98504-7827
No. of

Copies

L. Seelatsee

Wanapum People

Grant County PUD

30 "C" Street

P.O. Box 878

Ephrata, WA 98823

P. Sobotta

Nez Perce Tribe

P.O. Box 365

Lapwai, ID 83540-0365

\section{ONSITE}

4 U.S. Environmental Protection Agency

N. Ceto

B5-01

D.A. Faulk

B5-01

L.E. Gadbois

B5-01

M.L. Goldstein

B5-01

6 Washington State Department of Ecology

F.W. Bond

$\mathrm{H} 0-57$

D. Goswami (3)

$\mathrm{H} 0-57$

J.A. Hedges

$\mathrm{H} 0-57$

J. Price

$\mathrm{H} 0-57$

2 DOE Office of River Protection

R.W. Lober

H6-60

R.M. Yasek

H6-60

8 DOE Richland Operations Office

B.L. Charboneau

A6-33

B.L. Foley

A6-38

J.P. Hanson

A5-13

R.D. Hildebrand

A6-38

J.G. Morse

A6-38

K.M. Thompson

A6-38

DOE Public Reading Room (2)
H2-53 
No. of

Copies

5 Bechtel Hanford Inc.

K.R. Fecht

K.A. Gano

J.K. Linville

D.D. Teel

S.G. Weiss

8 CH2M HILL Hanford Group, Inc.

F.J. Anderson

A.J. Knepp

M.N. Jarayssi

F.M. Mann

W.J. McMahon

D.A. Myers

C.D. Wittreich

M.I. Wood

2 Fluor Federal Services

R. Khaleel

E6-17

R.J. Puigh

E6-17

9 Fluor Hanford, Inc.

J.V. Borghese

M.E. Byrnes

F.M. Coony

B.H. Ford

T.W. Fogwell

R. Jackson

V.J. Rohay

L.C. Swanson

M.E. Todd-Robertson

S.M. Stoller Corporation

R.G. McCain
No. of

Copies

39 Pacific Northwest National Laboratory

R.L. Aaberg

C. Arimescu

K3-54

M.P. Bergeron

K6-04

R.W. Bryce

K9-36

E6-35

J.W. Buck

K6-04

A.L. Bunn

K6-85

R.L. Dirkes

K6-75

D.W. Engle

$\mathrm{K} 5-12$

K6-04

P.W. Eslinger

K9-33

M.J. Fayer

K9-36

E.J. Freeman

K9-33

K9-33

K6-81

K5-12

K6-81

K6-04

K6-86

K6-81

K3-54

K9-33

K6-75

K3-54

K6-81

K9-33

K6-96

P7-22

K3-54

K6-04

K9-33

K9-33

K9-36

K9-36

P8-55 